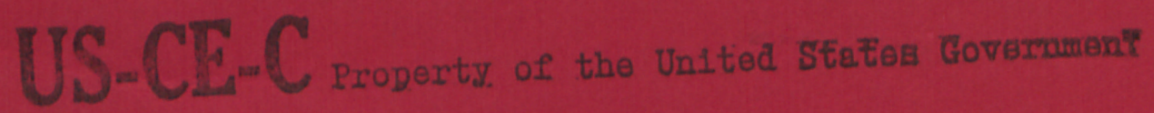
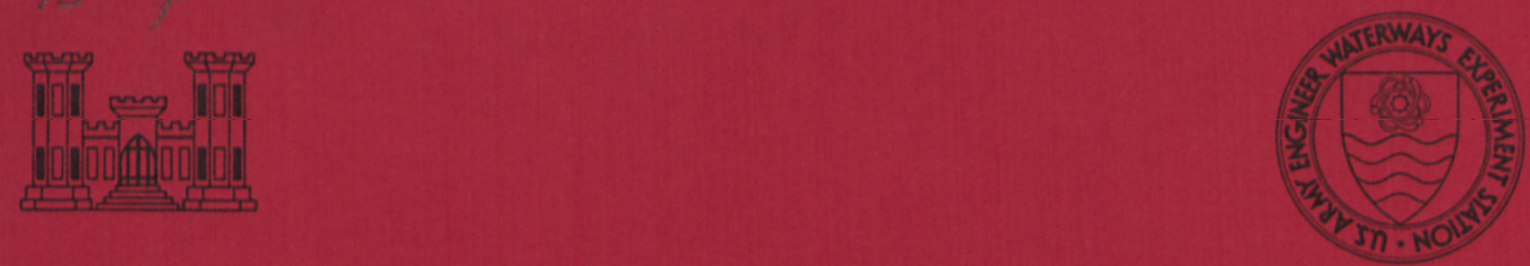

CONTRACT REPORT S-75-4

\title{
NUMERICAL ANALYSIS OF PROJECTILE IMPACT AND DEEP PENETRATION INTO EARTH MEDIA
}

by

\author{
M. H. Wagner, K. N. Kreyenhagen, W. S. Goerke \\ California Research and Technology, Inc. \\ 6269 Variel Avenue, Suite 200 \\ Woodland Hills, Calif. 91364
}

August 1975

Final Report

Approved For Public Release; Distribution Unlimited

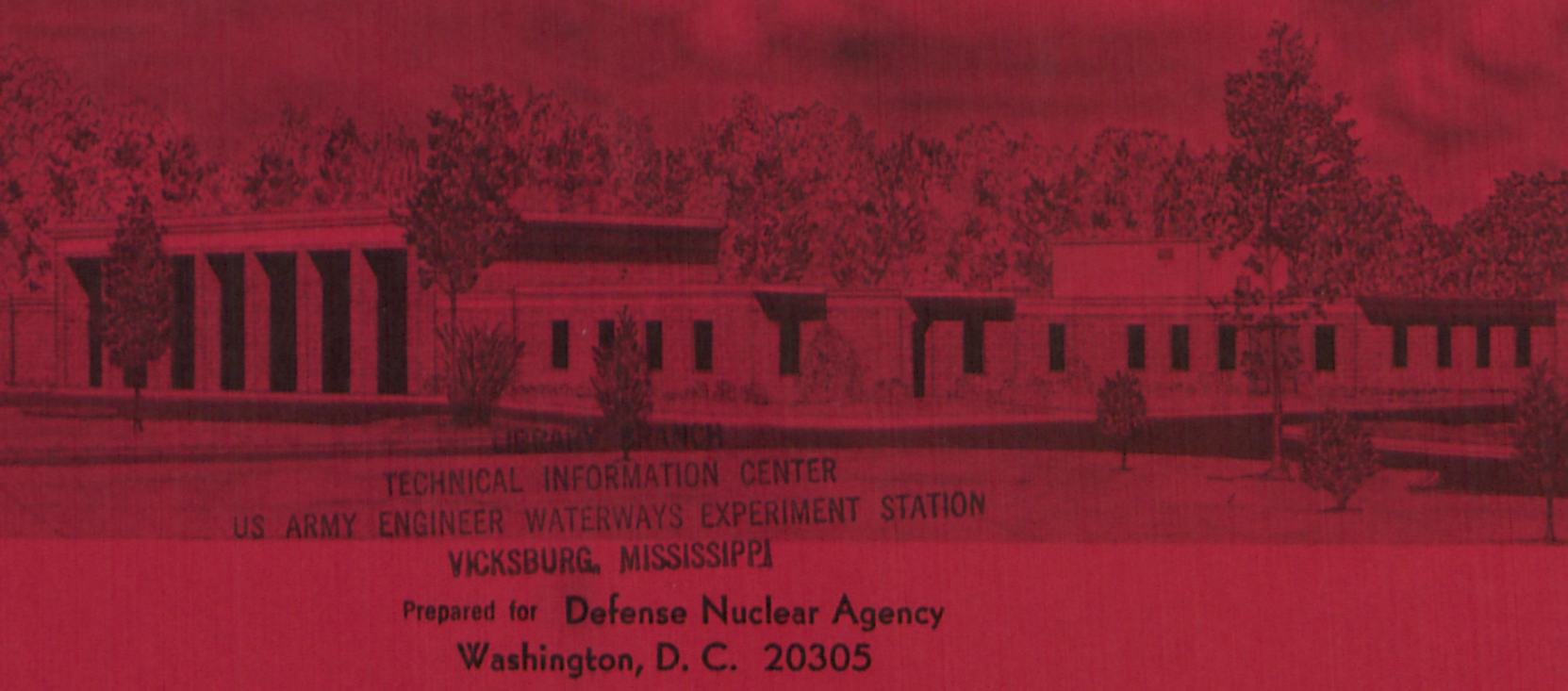

Subtask SB209, Work Unit 13, "Contract Support Studies of Ground Shock Propagation Through Soils and Rock"

Under Contract No. DACA39-74-C-0007

Monitored by Soils and Pavements Laboratory

U. S. Army Engineer Waterways Experiment Station

P. O. Box 631, Vicksburg, Miss. 39180 


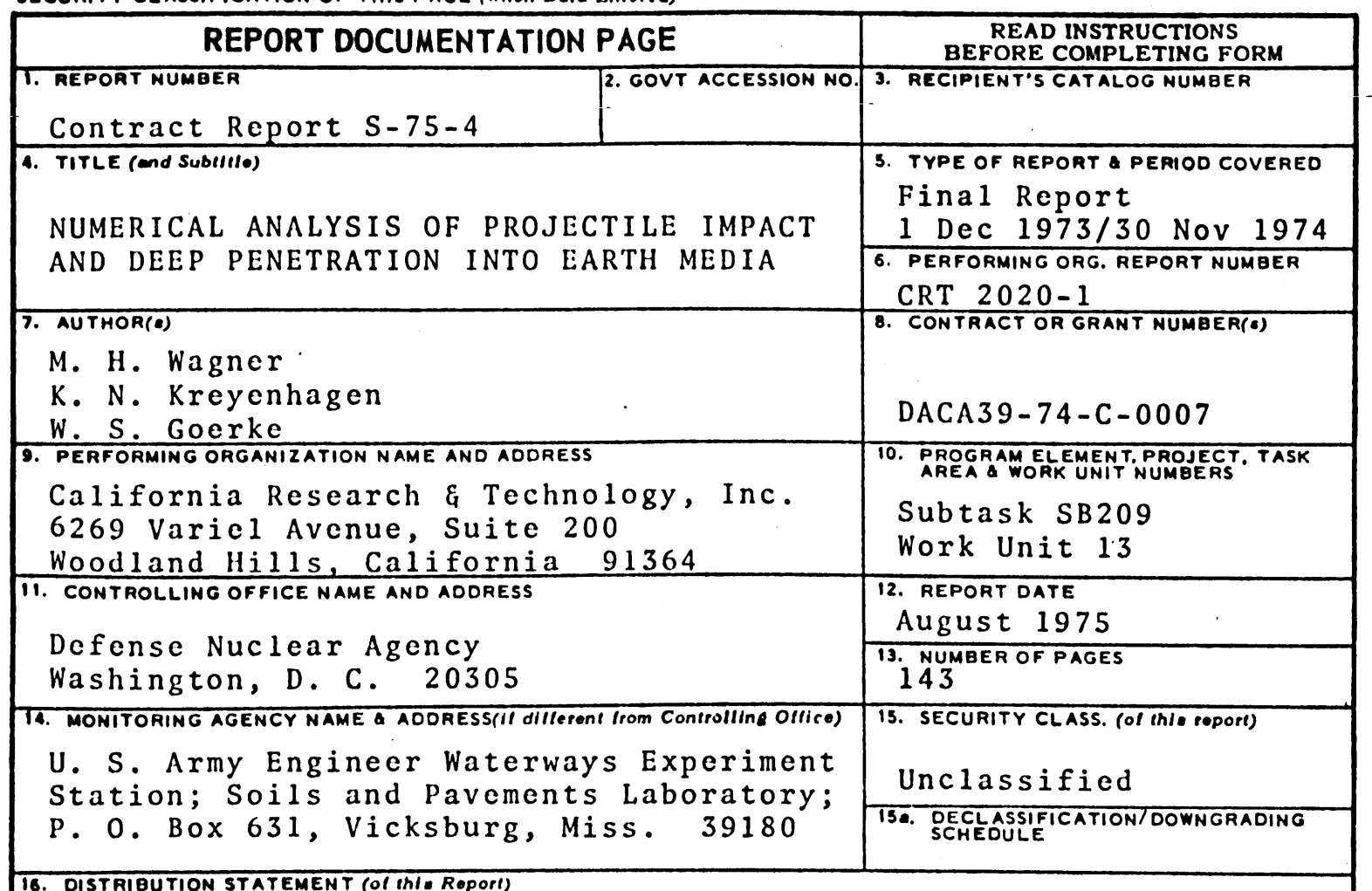

Approved for public release; distribution unlimited.

17. DISTRIBUTION STATEMENT (ol the abstract enfered in Block 20, 1 dillerent from Roport)

18. SUPPLEMENTARY NOTES

19. KEY WORDS (Conlinue on reverce elde If neceseary and Isentlly by block number)

Penetration

Terradynamics

Finite-difference codes

Soil mechanics

20. ABSTRACT (Conlinue on reverse elde ll neceesary and ldenilfy by block number)

A study was carried out to examine the utility, and some of the limitations, of using a finite-difference Lagrangian code to analyze relatively deep penetrations of projectiles into earth media. Numerical solutions were obtained for the normal impact of an 8-in. dia, 602-1b steel ogival projectile at 2000 fps into a soil/shale layered target. Two types of analyses were performed. In the first, the soil response, penetration 
dynamics, and projectile response were analyzed as one problem. The projectile was treated as an elastic-plastic, or deformable body, in order to determine the internal stress response. This computation was carried out for just the initial phase of penetration, until the nose was fully embedded in the soil. Problems were encountered with large numerical oscillations in the forces applied to the projectile (due to the strongly hysteretic soil model and to severe distortion of computational cells in the target). These problems can be overcome, but this type of calculation would still be cumbersome and time-consuming, due to the markedly different nature of the projectile response (primarily small, elastic strains) and of the soil response (severe plastic flow).

A more practical approach is to separately analyze the penetration dynamics and the projectile response. This can be done by first calculating the penetration of the projectile treated as a non-deforming (rigid) body, thus determining the histories of projectile acceleration, velocity, and depth, as well as the spatial and temporal distribution of forces acting on the body. These force distributions can then be used as boundary conditions in a separate analysis of the internal stress dynamics of the projectile.

In the second analysis, the projectile was treated as a rigid body, and its penetration to a depth of $22 \mathrm{ft}$ was calculated. The average deceleration was $390 \mathrm{~g}^{\prime} \mathrm{s}$ in the soil and $440 \mathrm{~g}$ 's in the shale. The final velocity was $1984 \mathrm{fps}$. This is a more efficient approach, but it will still be very time-. consuming to calculate an entire penetration event in this manner. Fortunately, because of the quasi-steady state nature of penetration processes within a nominally homogeneous geologic layer, it is not necessary to calculate the entire penetration. The penetration dynamics and critical force loading conditions on the projectile can be determined with reasonable accuracy by analyzing just the initial embedment and those periods where the projectile is entering different geologic layers. 


\section{PREFACE}

This report describes a research program to investigate the feasibility of the application of a two-dimensional finite-difference code for the prediction of projectile penetration into earth media. It was conducted for the U. S. Army Engineer Waterways Experiment Station (WES) by California Research and Technology, Inc. (CRT), under Contract DACA39-74-C-0007. This program was sponsored by the Defense Nuclear Agency (DNA) under Subtask SB209, Work Unit 13, "Contract Support Studies of Ground Shock Propagation through Soils and Rock".

The principal investigator at CRT was M. H. Wagner. Technical advice and guidance were contributed by $K$. N. Kreyenhagen. W. S. Goerke performed the computer programming and code development work. C. C. Fulton and G. E. Eggum provided valuable assistance in formulation of the material. models and data reduction, and in the computer production runs, respectively.

The penetrator specifications, site profile, and material properties were provided by WES.

The Contracting Officer's Representative was D. K. Butler of WES. The contract was monitored and coordinated with the overall DNA penetration program under DNA Subtask SB211, Work Unit 03, "Contract Support Studies of Projectile Penetration and Impact". A. J. Breithaupt was the Contracting Officer and Col. G. H. Hilt was the Director of WES during this contract investigation. 
SECTION I INTRODUCTION AND SUMMARY. . . . . . . 1

1.1 Objective .............. 1

1.2 Approach. . . . . . . . . . . . 2

1.3 Summary of Results. . . . . . . 3

SECTION II PROBLEM DESCRIPTION . . . . . . . 6

2.1 Penctrator. . . . . . . . 6

2.2 Sitc .............. 6

SECTION III COMPUTATIONAL METHOD. . . . . . . . 14

3.1 WAVE-L Code . . . . . . . . . 14

3.2 Grid Decoupling. . . . . . . . . 14

3.3 Computation of Stresses Acting

SECTION IV PENETRATION OF ELASTIC-PLASTIC

(DEFORMABLE) PROJECTILE • • • . . . . 18

4.1 Grid Design . . . . . . . . . . . . 18

4.2 Deformable Projectile Solution Results 20

SECTION V RIGID-BODY SOLUTION . . . . . . . 33

5.1 Grid Design . . . . . . . . . 34

5.2 Rigid Projectile Solution Results.. 36

SECTION VI COMPARISONS OF DEFORMABLE-BODY

AND RIGID-BODY PENETRATIONS . . . . . 53

SECTION VII CONCLUSIONS AND RECOMMENDATIONS . . . 62

7.1 Rigid-Body Penetrations . . . . . 62

7.2 Projectile Response . . . . . . . 63

7.3 Numerical 0scillations . . . . . 64

REFERENCES .................. 66

APPENDIX A MATERIAL MODELS. . . . . . . . 67

APPENDIX B DISTORTION, VELOCITY, AND PRINCIPAL

STRESS FIELD PLOTS - DEFORMABLE-BODY

SOLUTION . . . . . . . . . . . 82

APPENDIX C DISTORTION, VELOCITY, AND PRINCIPAL

STRESS FIELD PLOTS - RIGID-BODY

SOLUTION . . . . . . . . . . . .105 


\section{SECTION I}

\section{INTRODUCTION AND SUMMARY}

\subsection{BACKGROUND AND OBJECTIVES}

A number of analytical and semi-empirical relationships have evolved over the years to predict projectile penetration into earth media. These can provide useful information about certain aspects of penetration, but in general, they are restricted in their applicability (relative to types of target media and the basic properties of such media), and they yield incomplete information about the forces acting on the projectile, and about the distribution of stresses within the projectile.

Finite-difference numerical methods have the potential for overcoming the limitations of purely analytical or semiempirical approaches for the following reasons:

a. The dynamic mechanisms of target response and of projectile-target interactions can be explicitly incorporated into the analysis.

b. The basic properties of target media (at actual or representative sites) can be incorporated into the analysis.

c. The analysis can yield time histories of (1) the force distribution applied to the projectile surface and the consequent projectile deceleration, velocity, and position, and (2) the stress distribution and deformations within the projectile and its internal components.

In the related area of armor penetration, finite-difference numerical techniques have been used, beginning in 
1967, for analysis of penetration dynamics and interactions between shape factors, material properties, and impact parameters (e.g., Refs. 1 and 2). Thigpen ${ }^{3}$ made the first app1ication of these techniques to earth penetration analyses. Despite fairly gross zoning of both the projectile and target media, he was able to obtain penetration depths into tuff and limestone which were in reasonable agreement with experimental results. However, serious practical problems were evident, particularly with respect to the computer times required for solutions with adequate zoning to resolve stress gradients, deformation, and failure processes in the target medium, and to describe realistic, non-solid, projectile designs.

The objectives of the current research have,been to expose and explore some of the practical problems in applying 2-D finite-difference solutions to a broad class of earth penetration problems, and to examine the utility of this general approach by means of demonstration problems.

This work, which was primarily carried out during the first half of 1974, established some of the foundation for the subsequent penetration and projectile response analyses which are described in Refs. 4 and 5. To our knowledge, for example, the approach of treating the projectile as a rigid body in the numerical analysis of earth penetration dynamics was first utilized during this program. This is an efficient technique which makes it possible to first analyze the severe target distortions associated with penetration by the projectile, and then, if desired, to separately analyze the response of the projectile itself. 


\subsection{APPROACH}

A representative but hypothetical earth penetration problem was chosen for analysis. It consisted of the normalincidence impact of an 8-in. dia, 602-1b steel ogival projectile at $2000 \mathrm{fps}$ into a fairly soft target consisting of soil over shale.

An existing two-dimensionsal finite-difference Lagrangian code, WAVE-L, was used as the basic numerical technique. WAVE- $L$ is based on the Hemp method. ${ }^{6}$

Two types of analyses of the projectile penetration were performed. In the first, the projectile was treated as an elastic-plastic, or deformable body. The stress response of the projectile and the deformation of the target medium during penetration were computed as a single, unified problem. This solution was carried out for the initial phase of penetration; i.e., until the projectile nose was fully embedded into the earth.

In the second analysis, the soil response and consequent forces acting on the projectile were computed as before using the regular elastic-plastic formulation of the WAVE-L code, but the projectile itself was assumed to be a rigid body. In typical earth penetration problems of interest, the projectile suffers only elastic strains, and these would not be expected to significantly interact with the severely-distorting target media or with the penetration processes. For purposes of analyzing the penetration dynamics and the forces applied to the projectile surface, it is therefore reasonable to assume that the projectile is a rigid body. This approach bypasses the detailed computation of the internal projectile response, thereby allowing a more rapid and efficient calculation of the penetration. This rigid-body solution covered penetration through the soil layer and into the sahle, to a total depth of $22 \mathrm{ft}$. 


\subsection{SUMMARY OF RESULTS}

Analysis of the penetration of the elastic-plastic, or deformable-body projectile was carried out for $0.8 \mathrm{msec}$, or to a depth of 20 inches into the soil layer. The nominal cell size in the target for this solution was $1 \times 1$ inch. After penetrating about 6 inches, the average deceleration reached about $585 \mathrm{~g}$ 's. This level persisted for the balance of the solution, indicating that interactions between the target soil and the first few inches of the nose tip essentially determined the penetration dynamics. The maximum stresses in the steel projectile occurred near the nosetip, which experienced about $3.5 \mathrm{~kb}$, and in the connecting section between the nose and the body of the projectile, which experienced nearly $4 \mathrm{~kb}$.

Large oscillations occurred in the force history applied to the deformable projectile due apparently to amplifying, synchronous interactions between the finite nature of the computational grid and the strongly hysteretic load-unload behavior given by the soil model. (A method for alleviating this problem was found during the rigid-body solution.) Despite this oscillation problem, the deformable-body penetration solution demonstrates the feasibility of obtaining a unifed solution of projectile penetration and projectile response. However, this is a cumbersome and time-consuming approach. A more practical approach is to analyze the penetration dynamics and projectile response as separate problems. From an analysis of the penetration of a rigid projectile, the surface loading on the projectile surface can first be determined. This loading can then be used as a boundary condition for analysis of the response of the elastic-plastic projectile itself. This approach has been used in Ref. 5 .

The rigid-body penetration solution was carried out for $11.5 \mathrm{msec}$. During this time, the projectile penetrated 
through $162 / 3 \mathrm{ft}$ of soil and about $5 \mathrm{ft}$ of shale. The nominal cell size in the target was $2 \times 2$ inches. The average deceleration level was about $390 \mathrm{~g}$ 's in the soil and $440 \mathrm{~g}$ 's in the shale. The discrepancy between decelerations in the soil layer from the deformable-body and rigid-body penetration solutions was probably due to the coarser zoning in the rigid-body case.

Large oscillations in the force history applied to the projectile also occurred in the rigid-body solution, but it was found that these were substantially alleviated by using a geometrically "predeformed" grid in the soil ahead of the projectile. This technique eliminated synchronous interactions and reduced the distortion of cells sliding out and around the nose tip. In strongly hysteretic target media, considerable care needs to be taken to realistically model the unloading and reloading behavior.

The rigid-body penetration solution demonstrates that finite-difference code solutions of deep penetrations are possible, although the cost for analyzing the complete penetrations of a high-velocity projectile into a soft earth target is likely to be high. Fortunately, it is not necessary to analyze the complete penetration in order to determine critical design conditions. In deep penetrations, the target response and penetration processes generally change only gradually with increasing depth within a homogeneous geologic layer. Under these circumstances, the penetration dynamics and the critical conditions of force loading on a projectile can be determined with reasonable accuracy by analyzing just the initial nose embedment period and the periods where the projectile nose is entering different geologic layers. This approach has been used in Reference 4 . 


\section{SECTION II}

\section{PROBLEM DESCRIPTION}

The conditions for the penetration solutions are summarized in Figure 1.

\subsection{PENETRATOR}

The projectile is shown in detail in Figure 2. It consists of a hollow cylindrical shell behind an ogival - nose section. The projectile cavity contains a 293-1b steel ballast mass which is connected to the outer shell by concentric rings. The total weight is $602 \mathrm{lb}$, and the weight/area (W/A) ratio is 12 psi.

For the deformable-body calculation, the steel projectile was treated as an elastic-perfectly plastic material having the properties listed in Table 1 . The equation of state and other details of the model for steel are contained in Appendix A.

For the rigid-body calculation, the only information required to characterize the projectile was the specification of the outer contour and the total weight.

\subsection{SITE}

The hypothetical target site profile consisted of a 16 2/3-ft-thick layer of soil over shale. Sets of property curves for these media were provided by Waterways Experiment Station (WES)? These curves were fit by the hysteretic, elastic-ideally plastic material models which are 


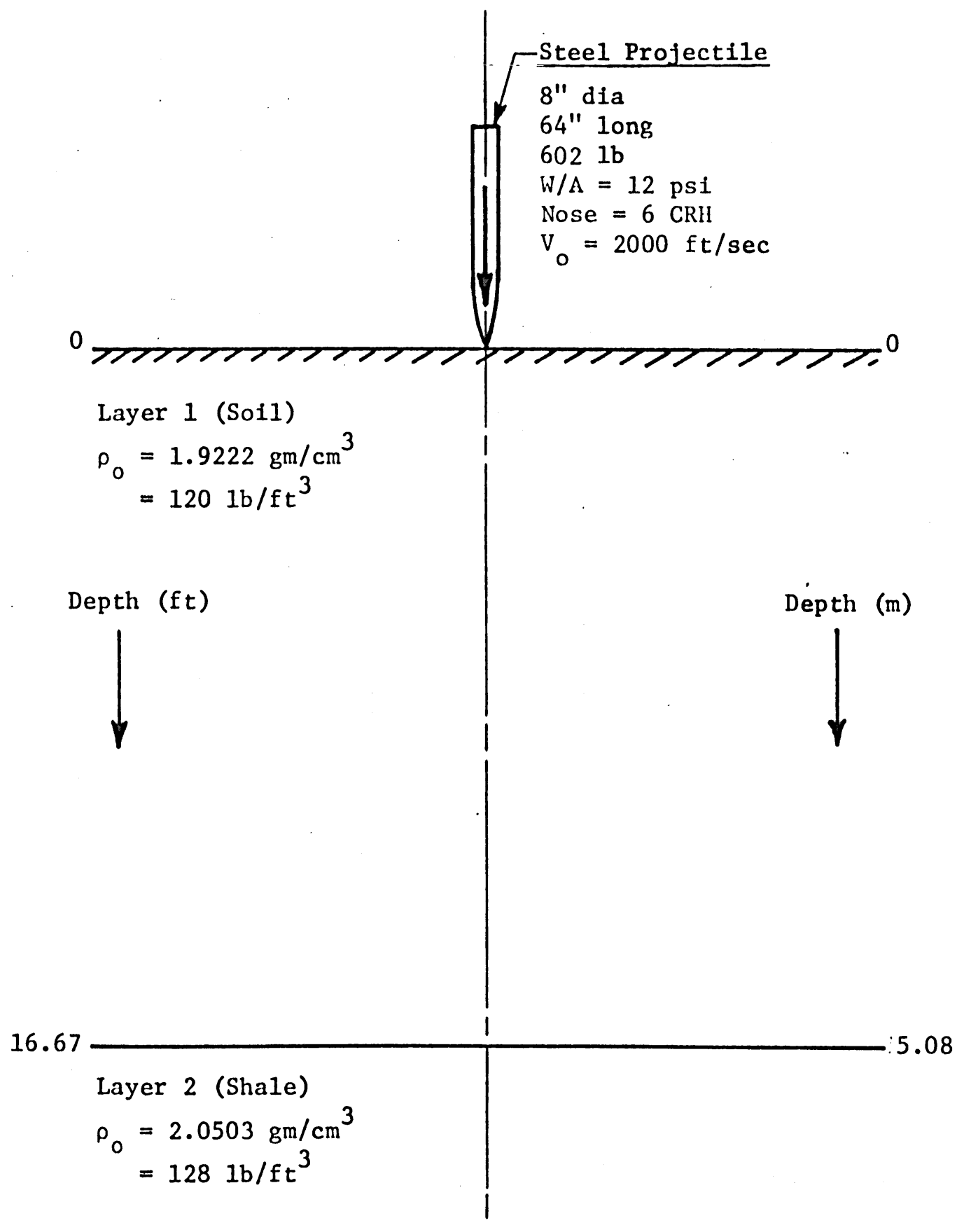

Figure 1. Overall Conditions for Numerical Solutions 


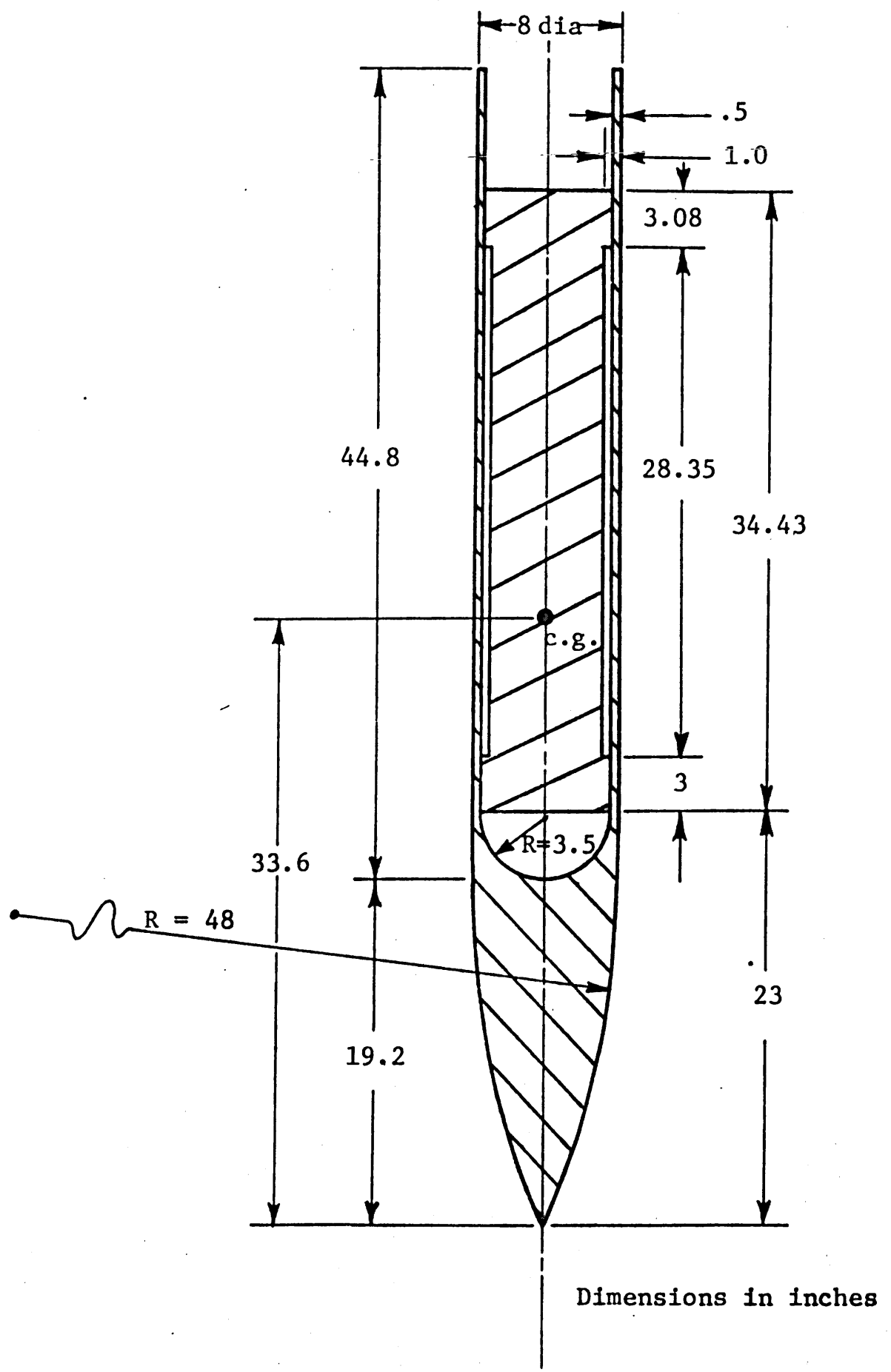

Figure 2. Penetrator Design 
TABLE 1. SUMMARY OF MATERIAL PROPERTIES

\begin{tabular}{lcccc} 
& & Layer 1 & Layer 2 \\
& & Projectile & $0-162 / 3 \mathrm{ft}$ & $>162 / 3 \mathrm{ft}$ \\
\hline Material & Steel & Soil & Shale \\
Density, $\rho_{0}, \mathrm{gm} / \mathrm{cm}^{3}$ & 7.84 & 1.9222 & 2.0503 \\
& $1 \mathrm{~b} / \mathrm{ft}^{3}$ & 489 & 120 & 128
\end{tabular}

Initial values of:

\begin{tabular}{|c|c|c|c|}
\hline Bulk modulus, $K_{0}$, psi & $2.445 \times 10^{7}$ & 4,237 & 83,180 \\
\hline Shear modulus, $G_{0}$, psi & $1.204 \times 10^{7}$ & 2,542 & 20,000 \\
\hline Poisson's ratio, $v_{0}$ & .289 & .25 & .389 \\
\hline $\begin{array}{l}\text { Dilatational wave velocity, } \\
c_{0} \text {, fps }\end{array}$ & 19,580 & 543 & 1,994 \\
\hline $\begin{array}{l}\text { loading wave velocity from } \\
\sigma_{z_{\max }}=15 ; 000 \text { psi, fps }\end{array}$ & & 6,656 & 6,846 \\
\hline confined compressive strength, psi & 50,000 & 59 & 564 \\
\hline $\begin{array}{l}\text { eld strength at } P=1000 \text { psi } \\
\text {, psi }\end{array}$ & 50,000 & 180 & 750 \\
\hline
\end{tabular}


described in Appendix A. Figures 3 and 4 show show the uniaxial strain load-unload paths provided by WES, together with the fits given by the models.

The models are seen to follow the WES curves quite we11, with the exception of the final portion of unloading in the strongly hysteretic Layer 1 . Figure 5 shows the shear failure surfaces. (The upper plot gives the low pressure region in detail.)

Table 1 summarizes the site media properties. 


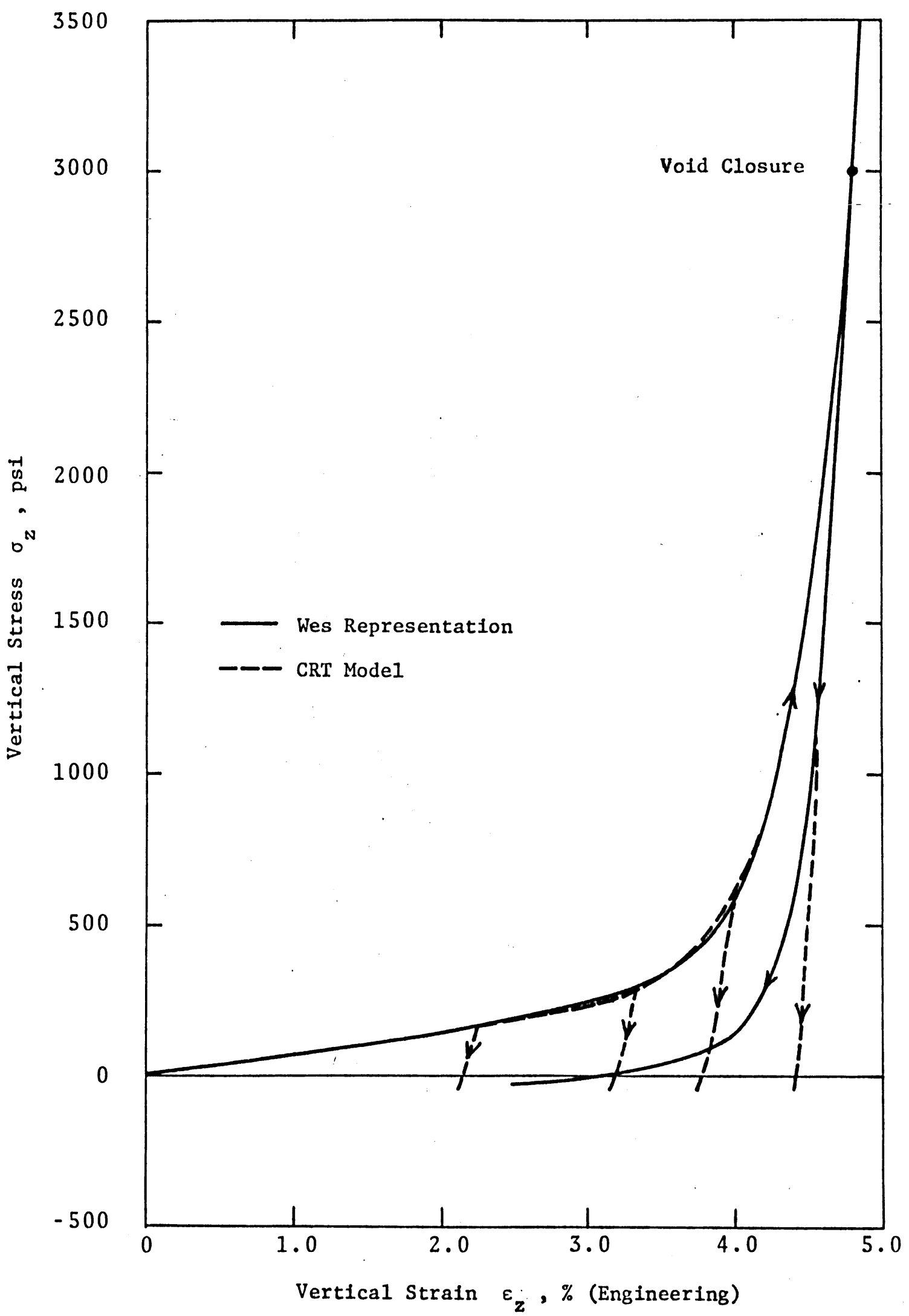

Figure 3. Uniaxial Strain Load-Unload Paths for Layer 1 (Sol1) 


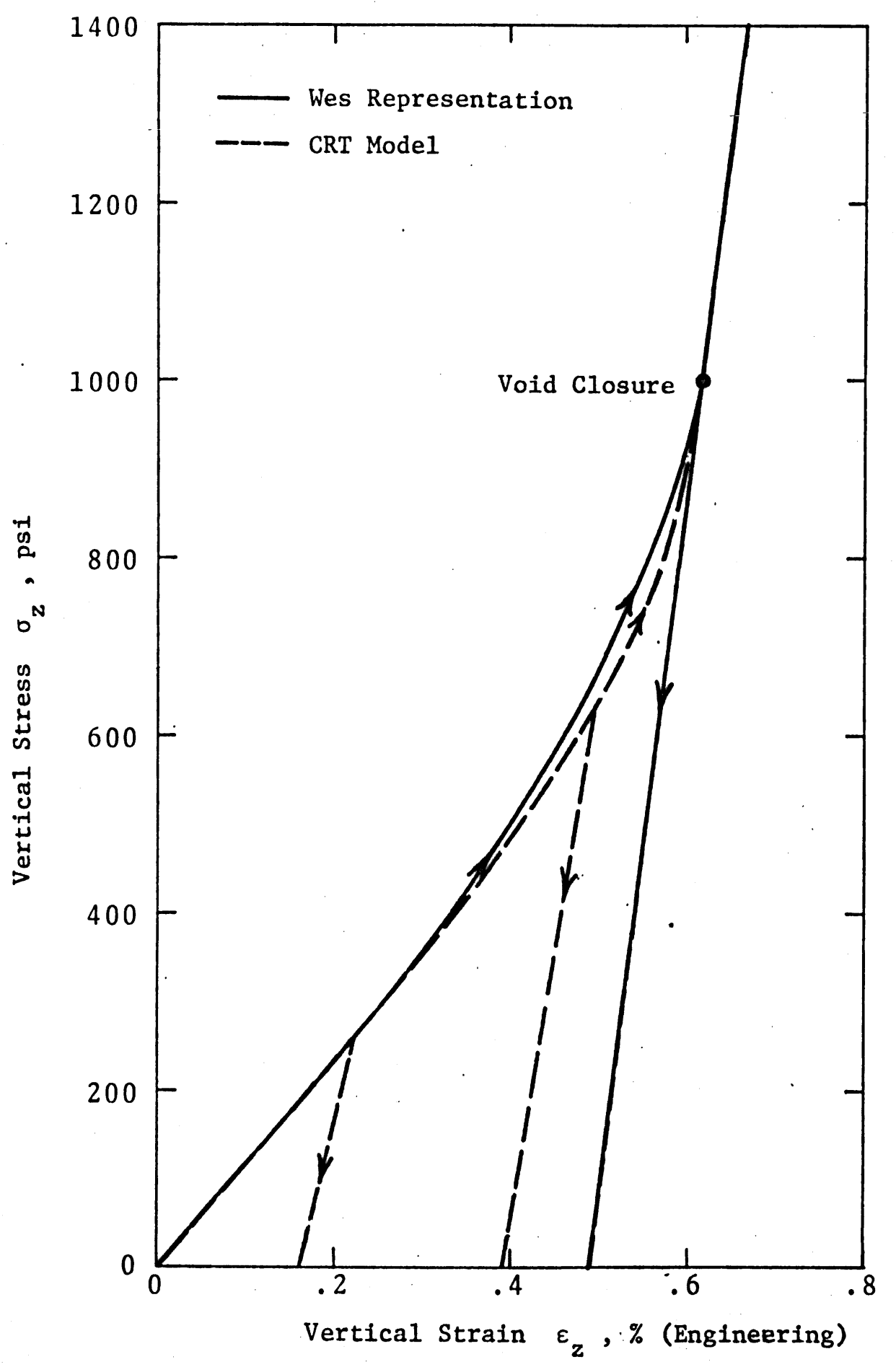

Figure 4. Uniaxial Strain Load-Unload Paths for Layer 2 (Shale) 

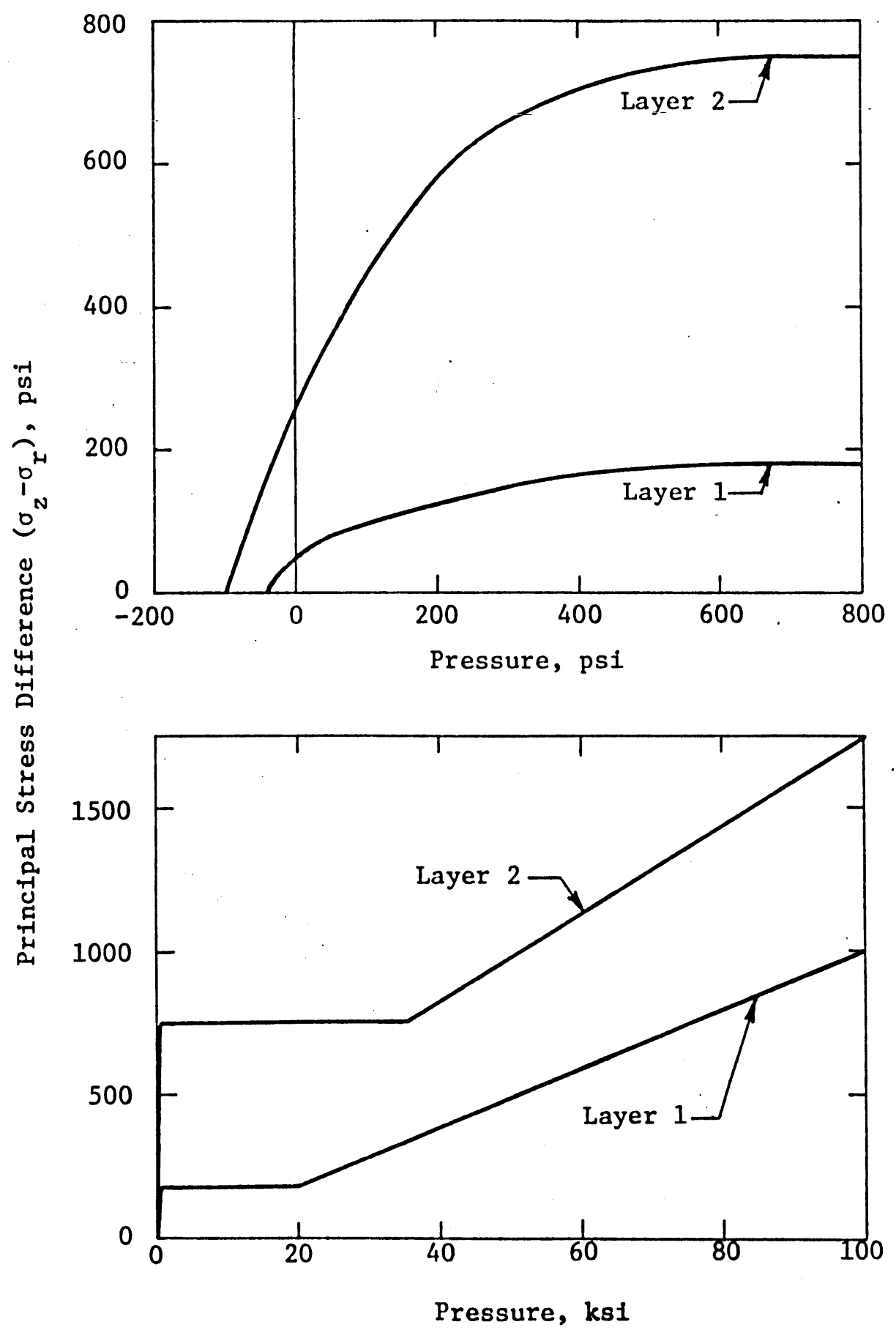

Figure 5. Shear Failure Surfaces for Layer 1 (Soil) and Layer 2 (Shale) 


\section{SECTION III}

COMPUTATIONAL METHOD

\subsection{WAVE-L CODE}

The WAVE-L code was employed for these calculations. WAVE-L is a two-dimensional code which solves the equations of motion for elastic-plastic bodies by means of a finitedifference Lagrangian-cell technique. The mathematical formulation is basically the same as that described by Wilkins. $\quad$ A sliding interface was used to allow penetration of the projectile through the computational grid. For these calculations, the projectile/target interface was assumed to be frictionless. A lithostatic field in the soil was generated by prescribing initially'compressed soil states.

\subsection{GRID DECOUPLING}

The sliding interface formulation in WAVE-L includes the capability for dynamically decoupling or unlocking the grid points when a prescribed decoupling or failure criterion is met. In a penetration problem, decoupling permits the cells initially attached to the axis to flow around the advancing nose shape, sliding along the interface. In these calculations, decoupling occurred when either the generalized plastic strain, $\bar{\varepsilon}$, in a cell adjacent to the axis, or the tensile stress, $-\sigma_{n}$, normal to the axis (slide line) exceeded critical values. Generalized plastic strain is defined ${ }^{8}$ as

$$
\bar{\varepsilon}^{p}=\int\left(\frac{2}{3} d e_{i j}^{p} d e_{i j}^{p}\right)^{\frac{1}{2}}
$$


and is a measure of the cumulative plastic deformation an element undergoes. $d \bar{\varepsilon}^{p}$ is always $\geq 0$, and thus $\bar{\varepsilon}^{p}$ monotonically increases as any type of plastic strain is experienced.

The critical generalized plastic strain and tensile stress values used for Layer 1 and Layer 2 were:

\begin{tabular}{|c|c|c|c|}
\hline & & $\bar{\varepsilon}_{\mathrm{c}}^{\mathrm{p}}$ & $-\sigma_{n_{c}}$ \\
\hline Layer & 1 (soil) & .07 & $40 \mathrm{psi}$ \\
\hline Layer & 2 (shale) & .013 & $120 \mathrm{psi}$ \\
\hline
\end{tabular}

During inigheiocity penetration, the soii fiowing arouna the nose often separates from the projectile before reaching the tangency point of the nose and cylindrical body. In these calculations, separation of a point could occur when the stress normal to the projectile was no longer compressive; i.e., $\sigma_{n}<0$. When this criterion is met, the point is moved as a free surface point and may subsequently collide with the penetrator, in which case it again becomes attached to the projectile. (Closing of the void would generally be expected during the final stages of deep penetration.)

\subsection{COMPUTATION OF STRESSES ACTING ON PROJECTILE}

The projectile contour is defined by a series of boundary points spaced along its periphery. (In an elasticplastic, or deformable projectile, these boundary points are corners of the cells used to describe the projectile.) The projectile surface line constitutes a slide line. 
Stresses are transmitted across the slide line in accordance with a friction rule. For both of the present calculations, the surface was assumed to be frictionless, so only normal stresses were transmitted across the slide 1ine. The normal stress applied to each surface segment of the projectile is determined as follows: Referring to the example shown in the sketch below, the stress components in a direction normal. to the projectile surface segment 2-3, are computed at the centroids $a$ and $b$ of the target cells which are in contact with the projectile surface segment. (In a Lagrangian code, stresses are cellcentered quantities.) By linear interpolation, the stress

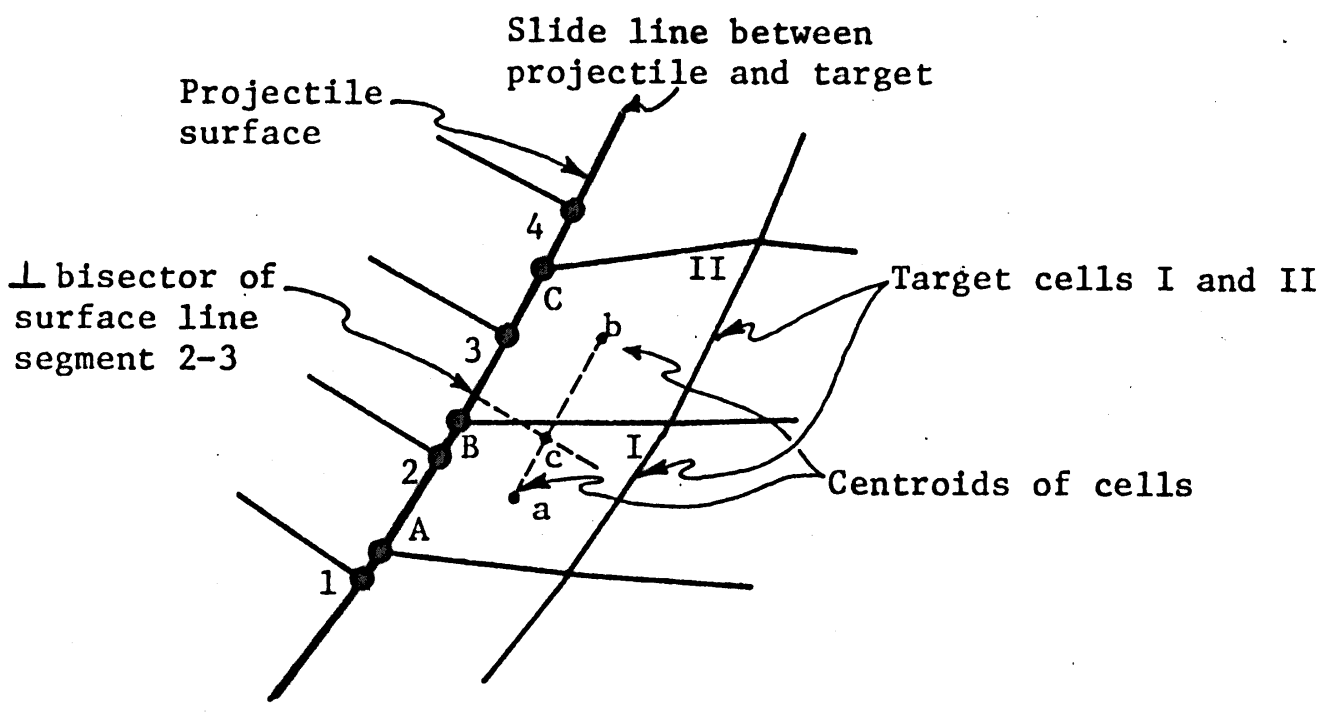


is determined at point $c$, which is the intersection of $a-b$ with the perpendicular bisector of the projectile surfacesegment 2-3. The component of stress at $c$ which is normal to $2-3$ is then applied all along 2-3.

An alternative method would be to apply to projectile surface segment $2-3$ the stress calculated for cell I over segment $2-B$ and the stress for cell II over segment B-3. This method becomes more inaccurate, however, when the target cells become severly distorted. 


\section{SECTION IV}

PENETRATION OF ELASTIC-PLASTIC (DEFORMABLE) PROJECTILE

In this solution, the penetration processes in the target soil and the response of the projectile were simultaneously analyzed for the interval from impact until the nose was fully embedded.

\subsection{GRID DESIGN}

The computational grid for analyzing the elasticplastic, or deformable-body penetration is shown in Figure 6. (The plot shows a complete cross-section of the axisymmetric problem. The actual grid contained only cells on one side of the axis.) The nominal zone size of the projectile was .5 inch in the radial direction (i.e., 8 cells across the radius) and 1.0 inch in the vertical direction. In the body of the projectile, the vertical zone dimension was gradually increased to a maximum of 1.7 in. at the rear of the projectile. There were about 300 cells in the projectile.

In the target medium, uniform $1 \times 1$ in. cells were used out to $16-$ in. radius, and down to 20-in. depth. Beyond this region, the radial and vertical cell dimensions gradually increased in a $2 \%$ geometric series. The overall grid extended to 26 -in. radius and 38 -in. depth, using about $900 \mathrm{cells}$ for the target. (Because of the high compressibility and low wave velocity in soil Layer 1 , the presence of the boundaries was not felt by the projectile during the 0.8 -msec duration of this calculation.) 


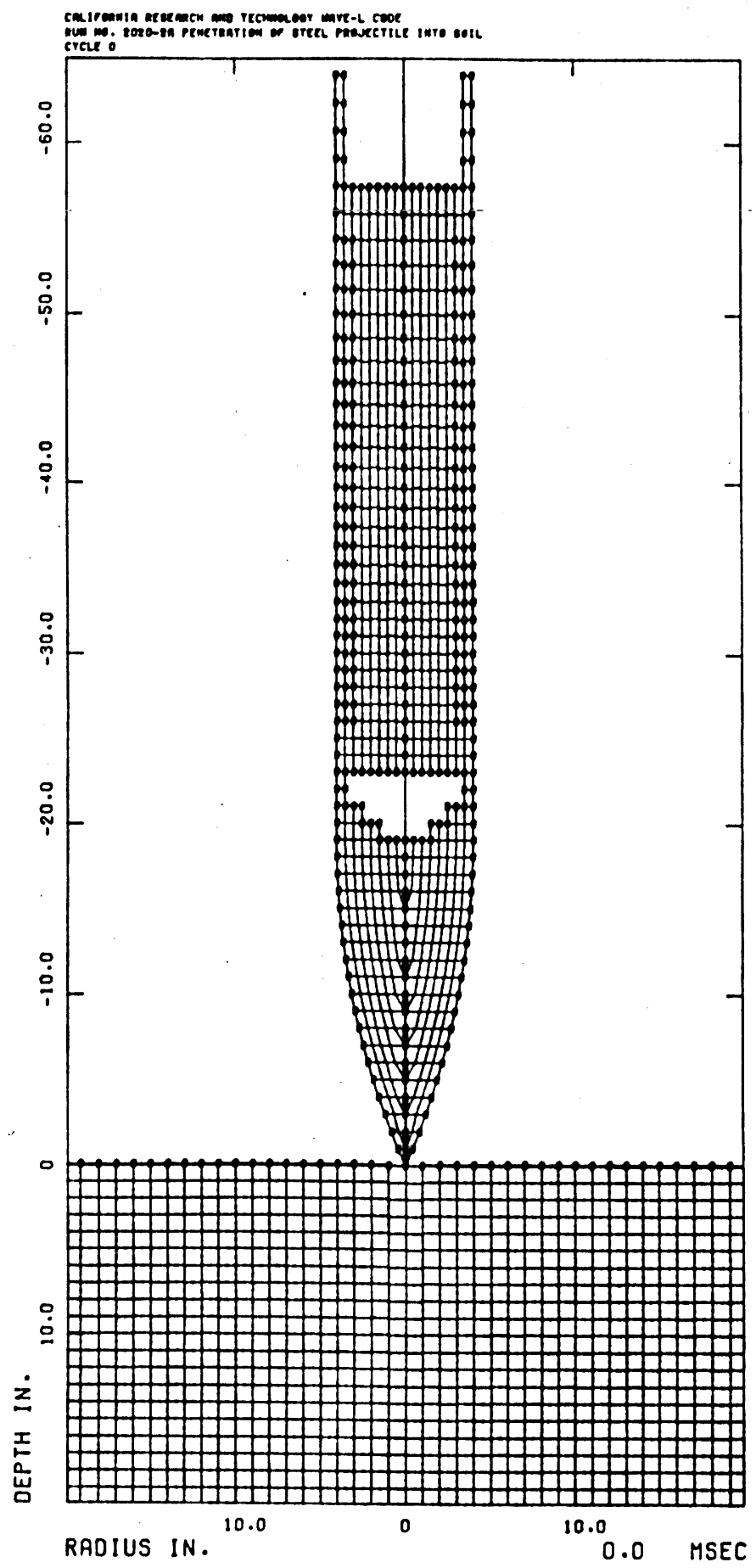

Figure 6. Initial Grid Configuration for Deformable Body Solution 
The $\mathrm{K}-1$ ine running along the penetrator contour and along the axis of the target was specified as a slide line. As the penetrator impinges into the target, this dual line defines the penetrator-soil interface and allows slippage and/or separation to occur.

The lattice points along the axis were initially coupled, and the projectile tip and the corresponding soil point were locked together. Thus, before the soil point at the surface could move out along the projectile nose surface, it had to decouple by having the associated soil cell fail according to the decoupling criterion described in Section III. Furthermore, since the points were initially locked together, the initial velocity of the soil point was equal to the projectile velocity. This produced an unrealistically high initial stress near the impact point. While the high stress decayed rapidly and probably did not significantly affect the overall solution, it was subsequently decided that it would be more realistic to have the nose and soil point at the origin initially decoupled and to assign zero initial velocity to the soil point. This procedure was used in the rigid-body penetration solution described in Section $V$.

\subsection{DEFORMABLE PROJECTILE SOLUTION RESULTS}

The deformable-projectile penetration solution was carried out until the nose was completely buried, with the tip at about 20 inches depth. This took $0.837 \mathrm{msec}$. The computational grid, particle velocity field, and principal stress field at this time are shown in Figures 7 to 9. 


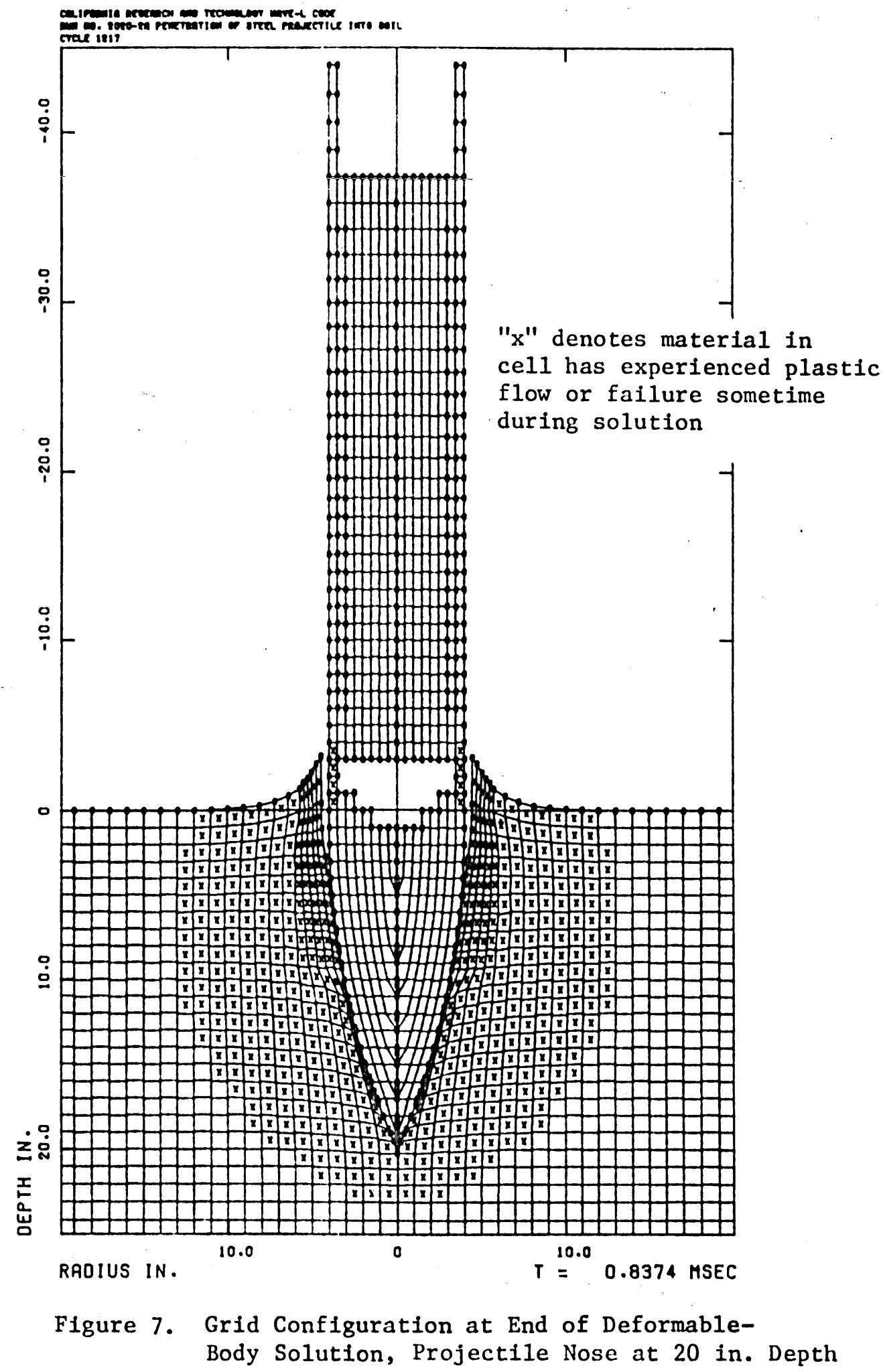




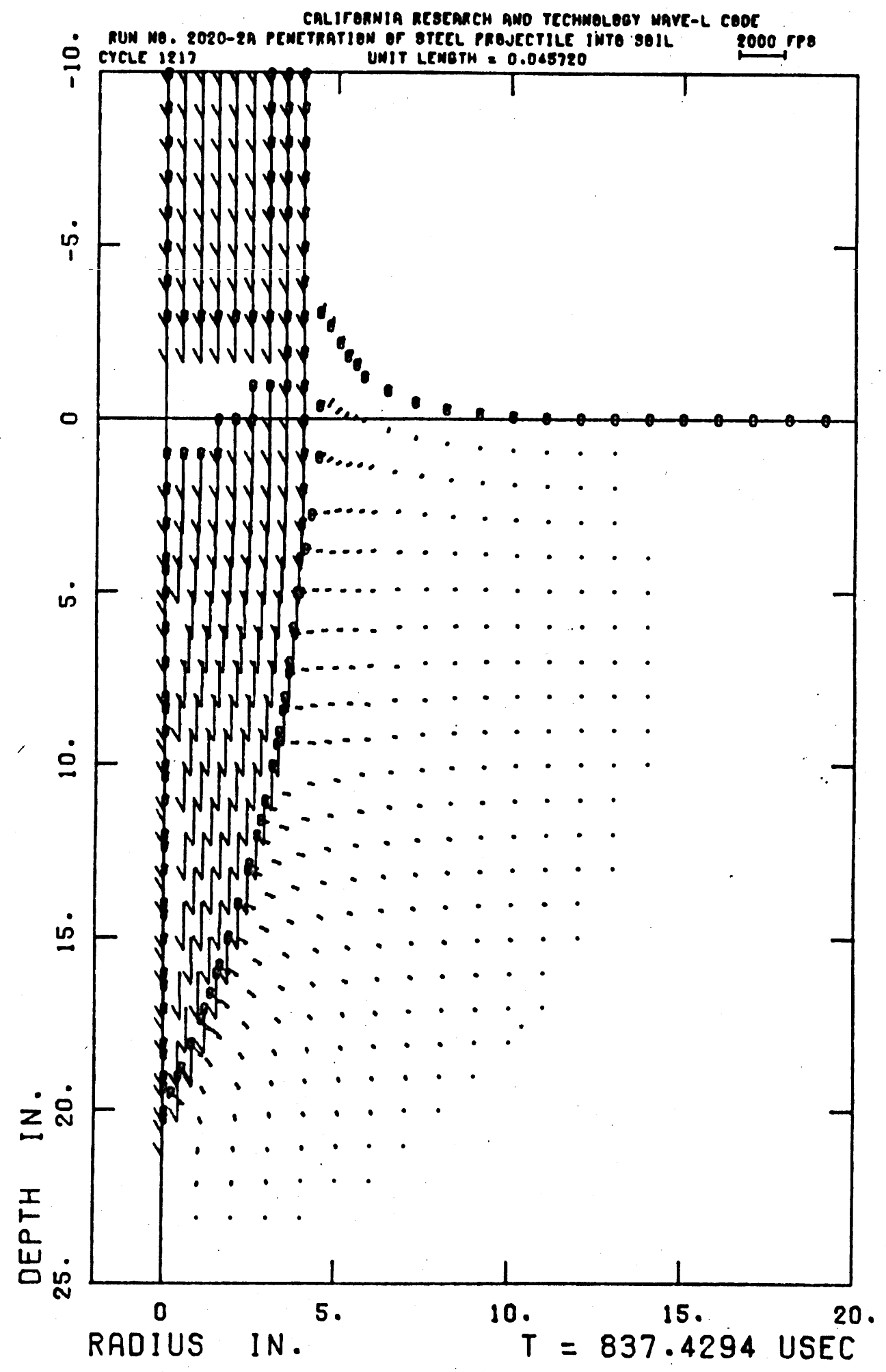

Figure 8. Particle Velocity Field at End of Deformable-Body Solution, Projectile Nose at 20 in. Depth 


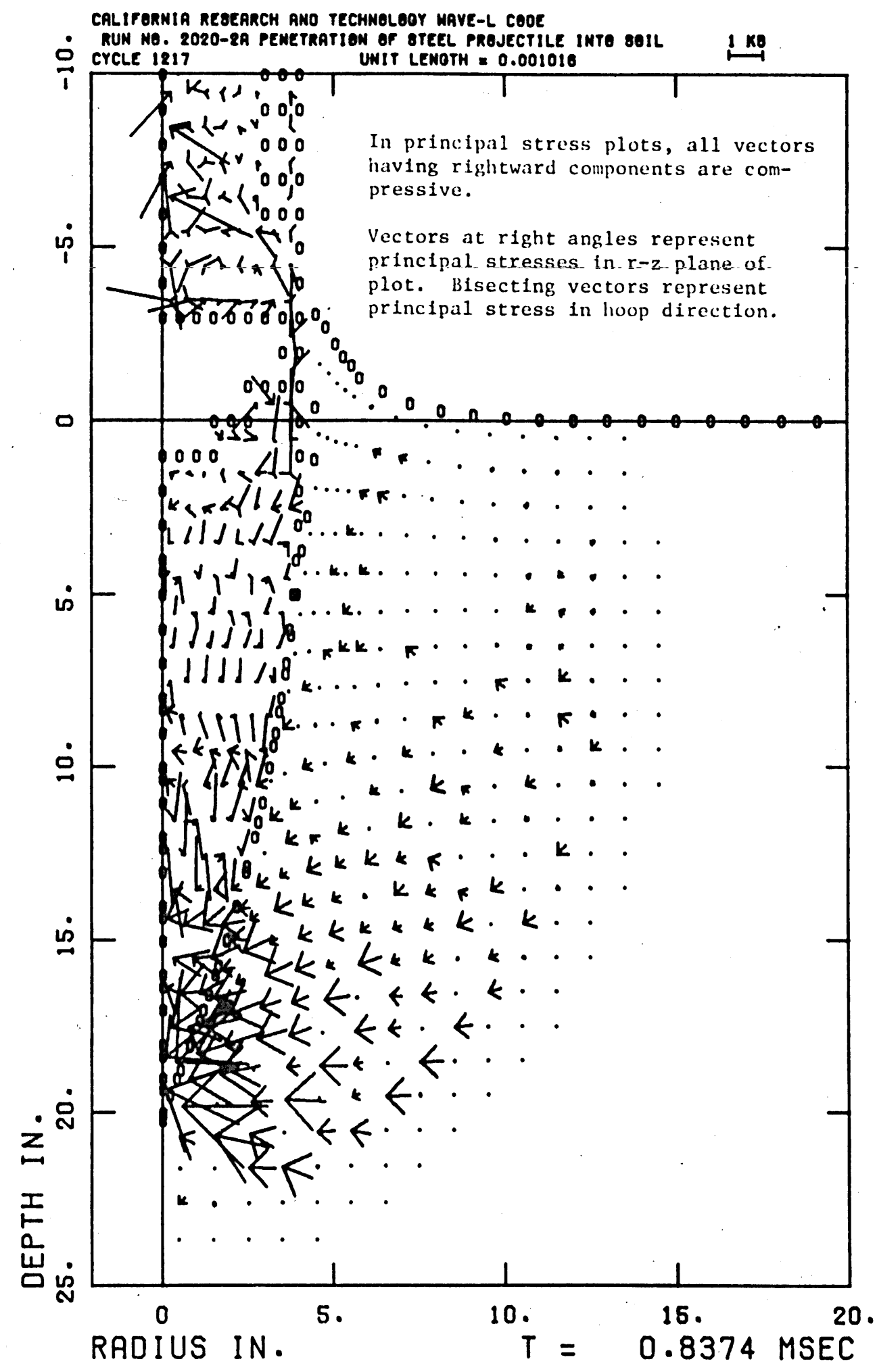

Figure 9. Principal Stress Field at End of Deformable-Body Solution, Projectile Nose at 20 in. Depth 
In the Lagrangian grid (Figure 7), the symbol " $x$ " in a cell indicates that material in that cell has experienced plastic flow or failure at some time during the solution. A volume of the soil extending outward to about 3 projectile radii and ahead of the nose tip about 1 radius has failed. The projectile response was entirely elastic, except for slight plastic deformation $(\bar{\varepsilon} \leq .35 \%)$ in the thin annular section connecting the nose with the body.

A series of the field plots obtained from this solution as the projectile entered the soil is given in Appen$\operatorname{dix}$ B.

- The dynamics of the overall projectile are summarized in Figures 10 to 12, which show time histories of the total axial force applied to the projectile, and resulting average deceleration and velocity, and depth of penetration. After about $.3 \mathrm{msec}$, corresponding to 6 inches of penetration; the average acceleration level had reached about $585 \mathrm{~g}^{\prime} \mathrm{s}$. This level persisted until the end of the solution, despite the fact that separation between the soil and projectile surface did not occur until about .56 msec when the nose tip was at about 11 inches depth. This indicates that axial forces applied by the soil to the first 6 inches of the nose tip were of predominate importance to the projectile dynamics of the problem.

The large oscillations which are apparent in the force and acceleration histories in Figure 10 are due to interactions between the finite nature of the computational zoning and the strongly hysteretic character of the unloading model used to describe the Layer 1 soil. This problem will be discussed further in connection with the rigid- 
Califonnia reseanch ano rechnoloor. InC.

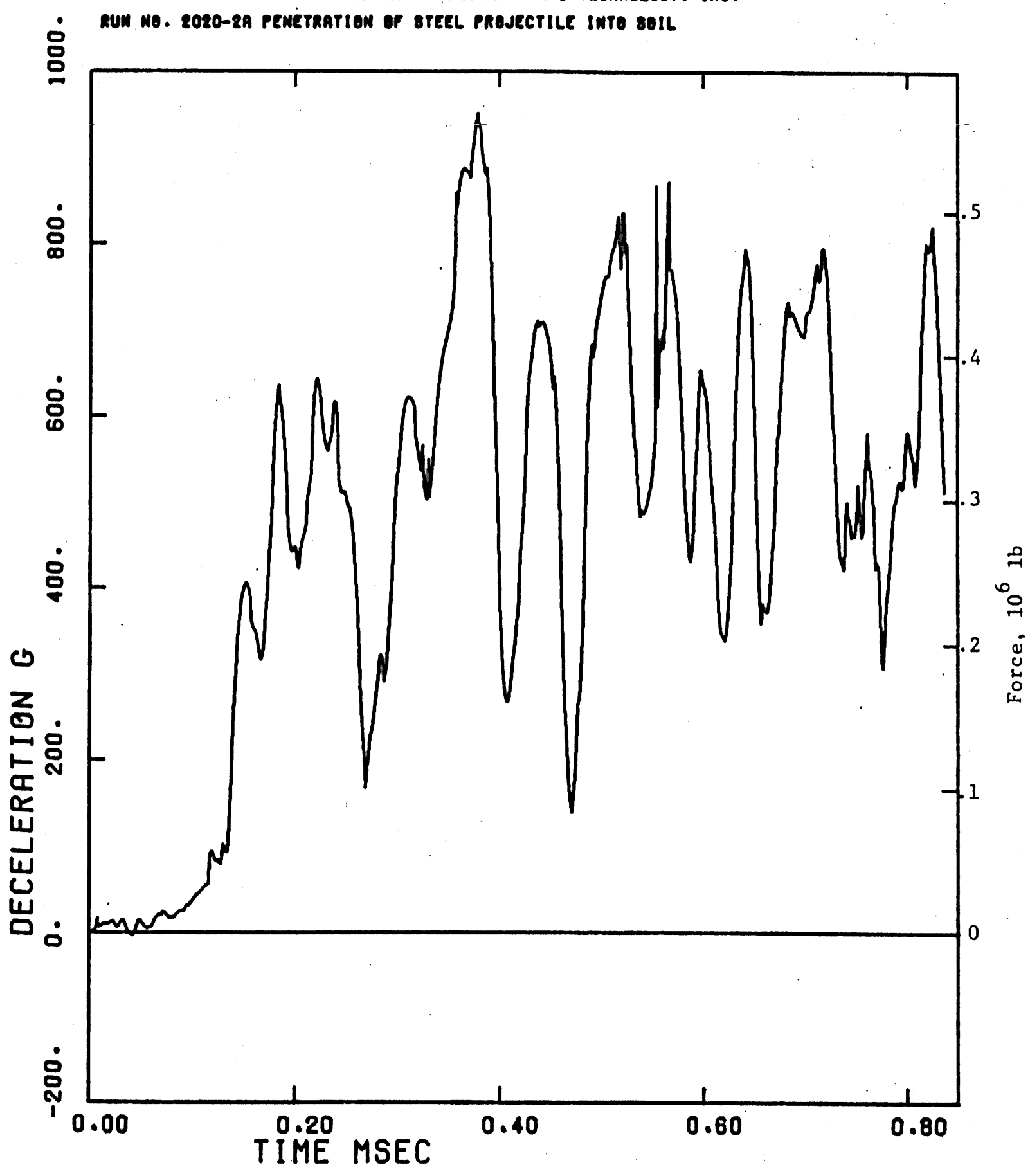

Figure 10. Axial Force on Projectile and Deceleration of Projectile vs Time, Deformable-Body Solution 
CALIFORMIA REOCARCH AMO TECHMOLOOY, INC.

RUN NO. 2020-8A PENETRATION OF BTELL PROJECTILE INTO.80IL

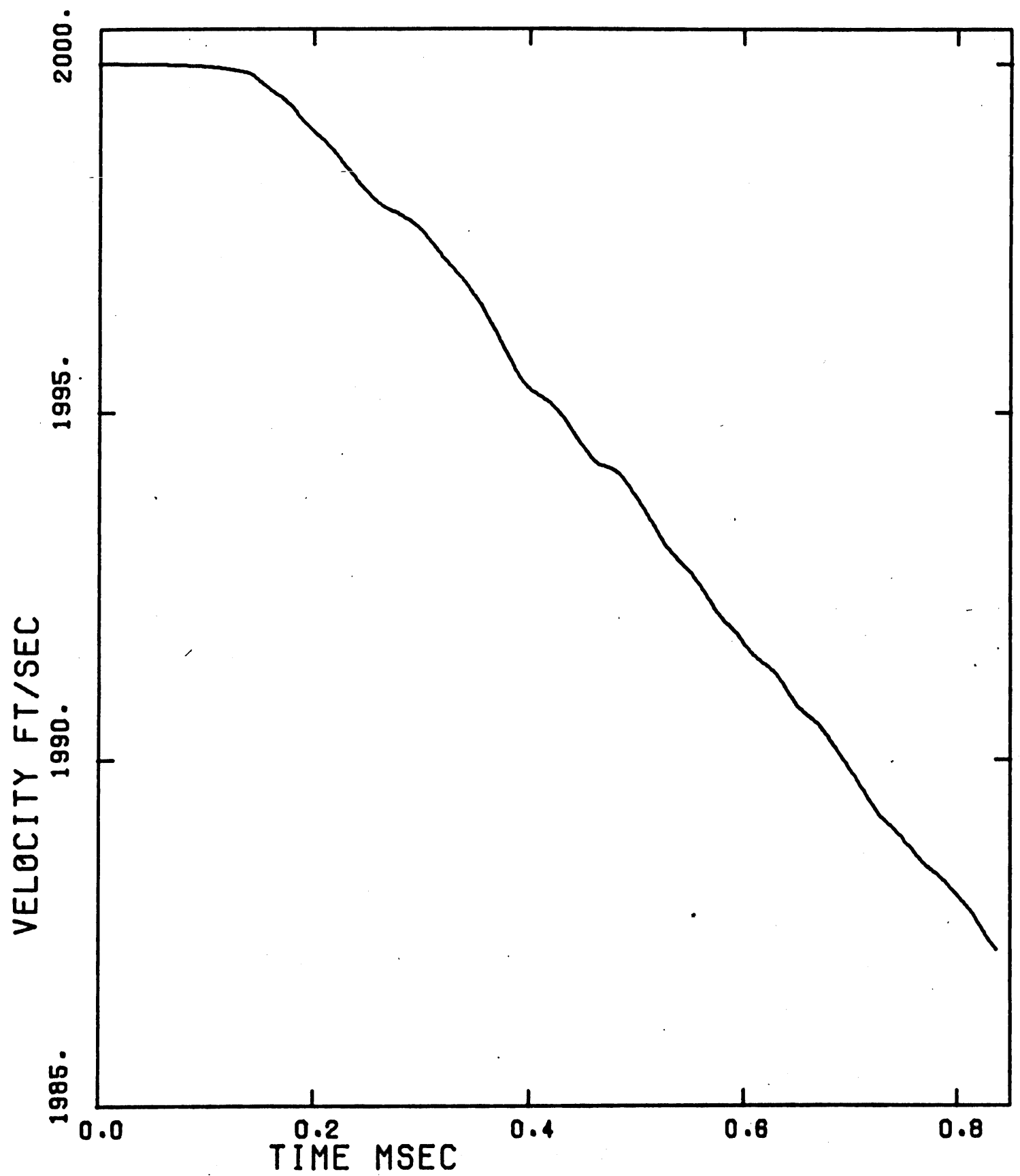

Figure 11. Project1le Velocity vs Time, Deformable-Body Solution 
I

CALIPORNIA REscaRCH ANO TEChNOLOOY. IMC.

RUN No. 2080-2a PENETRation of steel provectile InTO soll

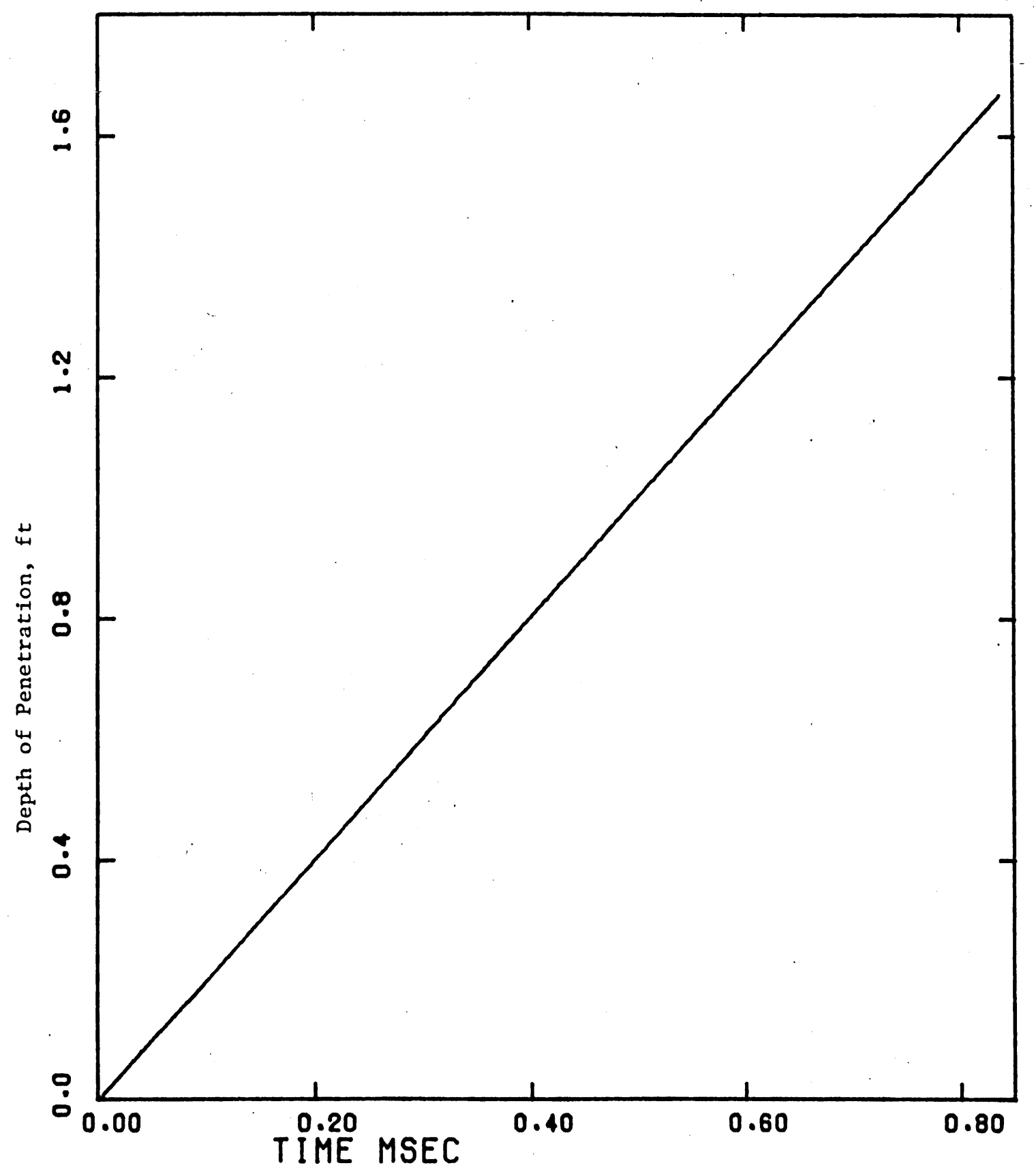

Figure 12. Depth of Penetration vs Time, Deformable-Body Solution

27 
body solution in Section VI.

Figure 13 summarizes the peak compressive stresses experienced in the projectile near its surface (solid curve) and along its axis (dashed curve). The peak values are probably overstated due to the numerical oscillations in the surface loading on the projectile, but they show the location of critical stress regions in the projectile. The highest stresses are experienced in the first 4 inches of the nose tip and in the thin annular region connecting the nose with the body. Relatively modest compressive stress levels are seen in the wall of the projectile. Some tension is experienced near the axis of the projectile, as is shown by the vectors having leftward components in Figure 9.

Figures 14 and 15 show mean normal stress vs distance profiles just inside the projectile surface at a sequence of times after impact, i.e. $\left(\sigma_{1}+\sigma_{2}+\sigma_{3}\right) / 3$ in the row of -steel cells along the periphery of the projectile. The progression of increasing stress along the projectile is seen. All of the profiles after . $1 \mathrm{msec}$ show a sharp drop about 5 in. back from the nose tip. At later times, the mean normal stress peaks again in the narrow connection between the nose and body (near 20 inches). Figure 16 shows mean normal stress vs distance profiles along the projectile axis. Tension occurs at the leading surface of the slug. The decelerating force on the cylindrical slug is being applied only around its periphery. This produces tension in the unsupported front surface.

Stress, velocity and displacement histories were obtained at several stations in the soil and within the projectile. These are available to interested readers in unpublished form at WES. ${ }^{9}$ 


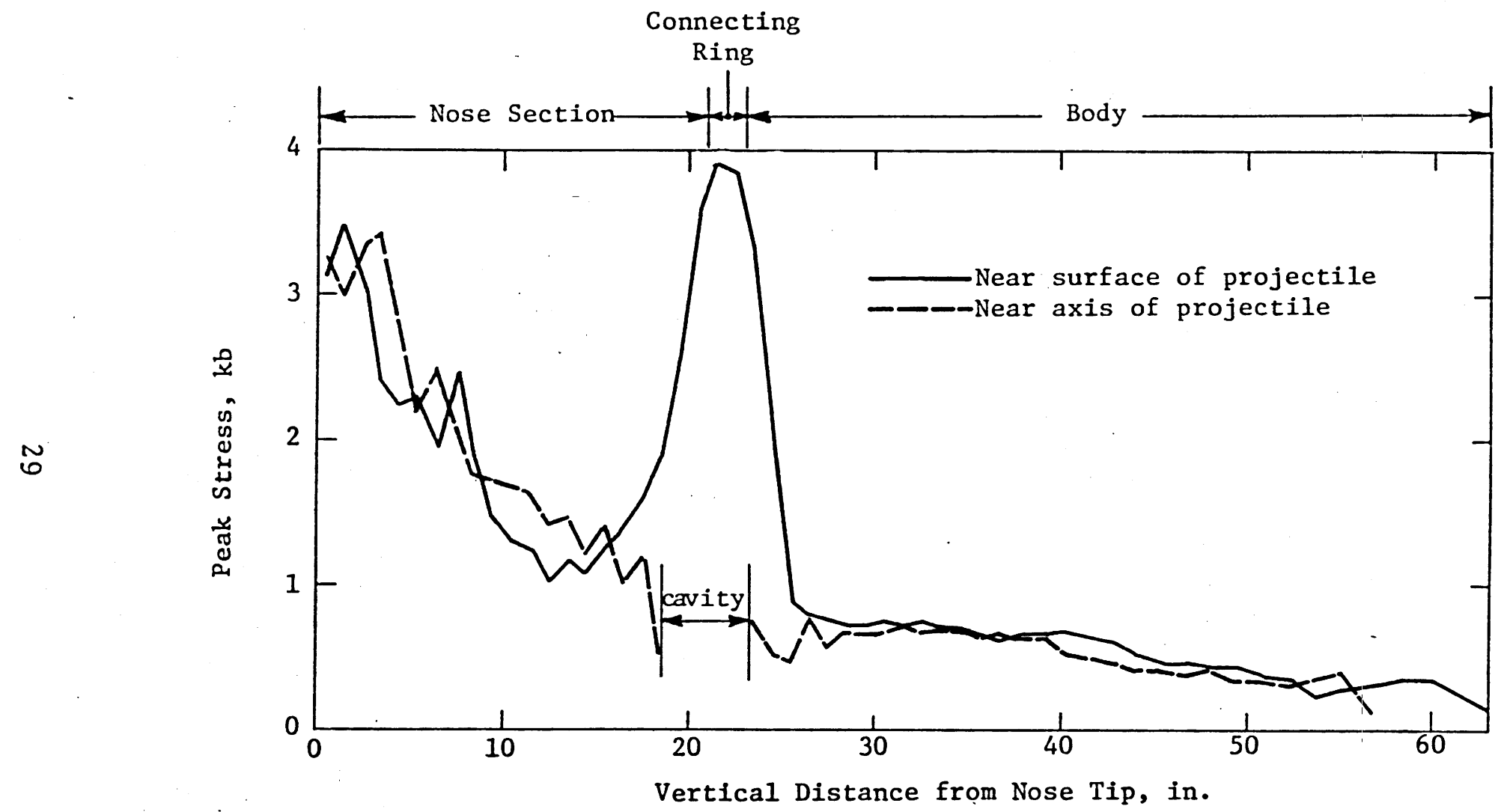

Figure 13. Peak Compressive Stresses Experienced in Projectile 


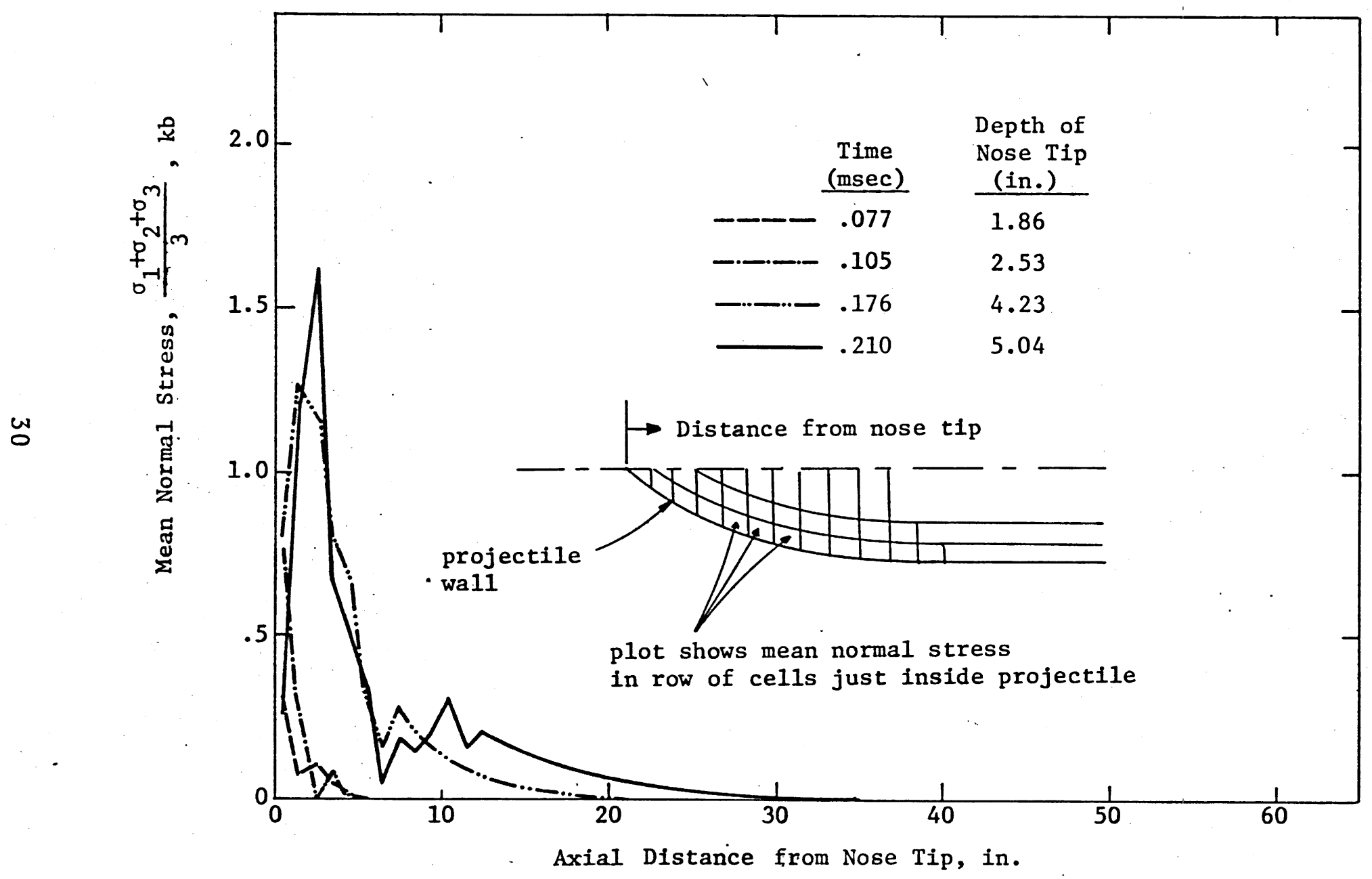

Figure 14. Early-Time Profiles of Mean Normal Stress Just Inside Projectile Wall 


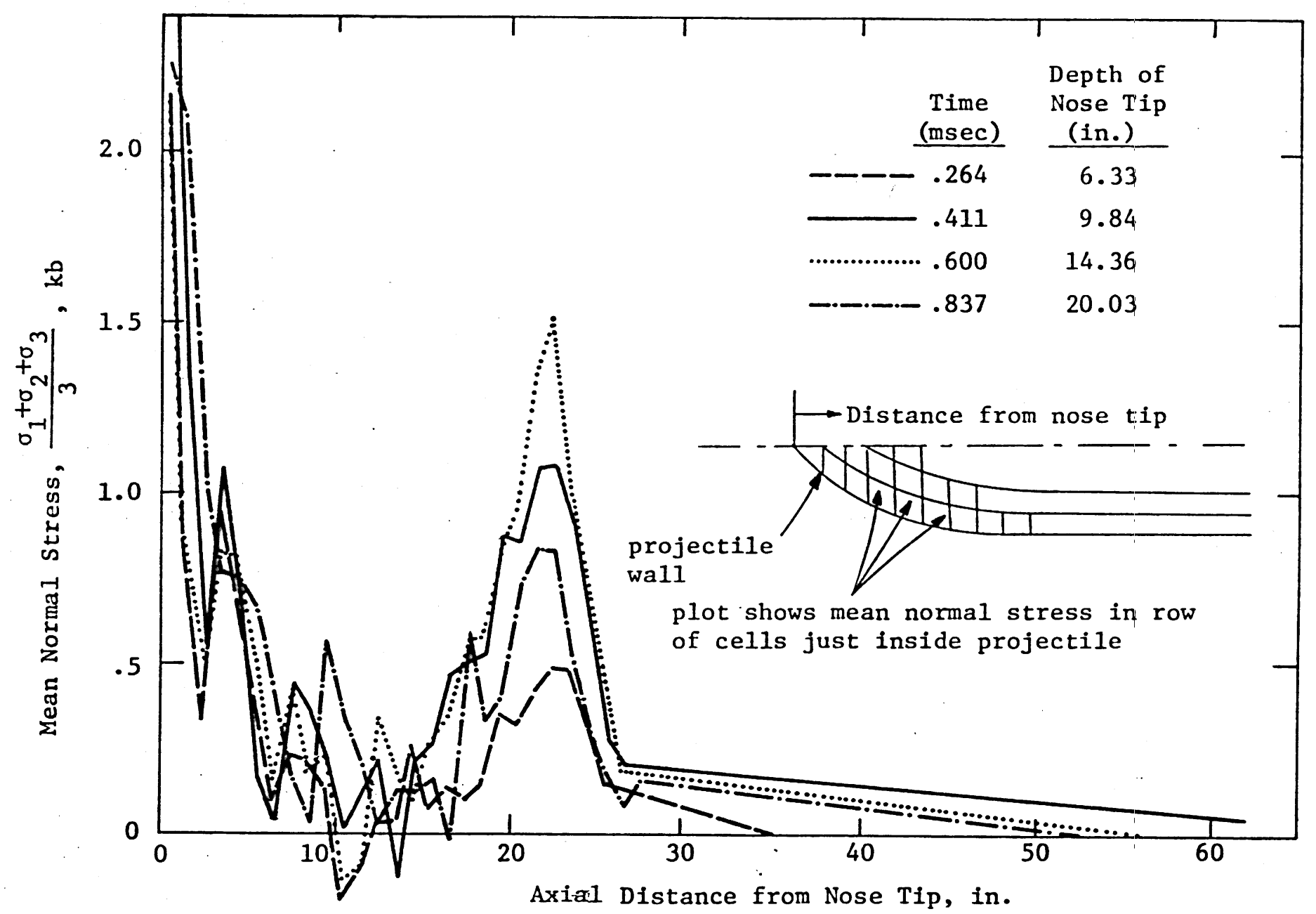

Figure 15. Later-Time Profiles of Mean Normal Stress Just Inside Projectile Wall 


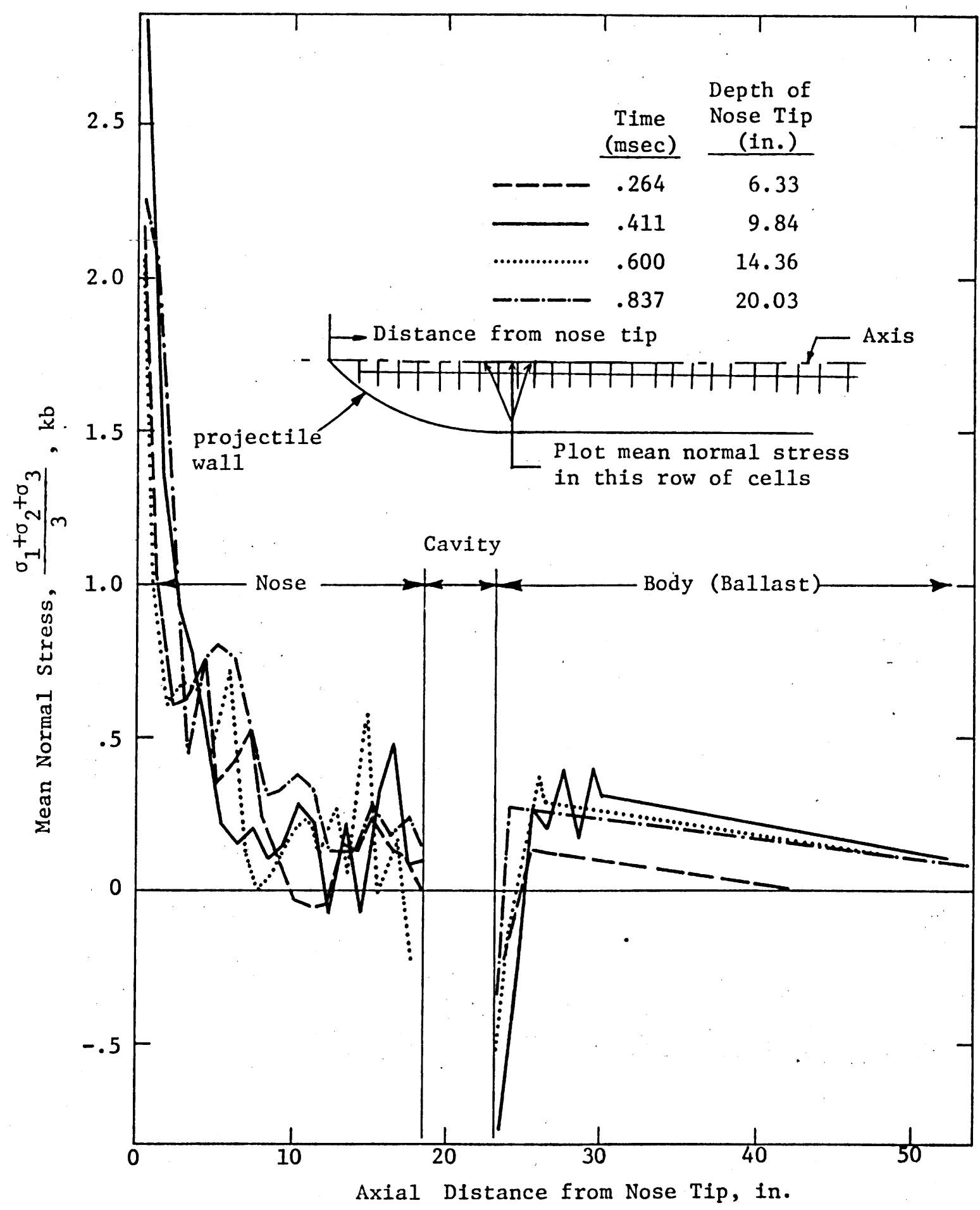

Figure 16. Mean Normal Stress Profiles Along Projectile Axis 


\section{SECTION V}

\section{RIGID-BODY SOLUTION}

In a deep penetration, the target material undergoes large distortions, while the projectile does not generally undergo any significant plastic deformation. To analyze the long-time processes of deep projectile penetration, including the projectile response, with a complete elasticplastic code solution would require an impractical amount of computer time. This situation can be alleviated by treating the projectile as a rigid body, while analyzing the soil response and consequent forces on the projectile surface using the regular elastic-plastic formulation of the code. The rigid-body assumption is justified so long as the projectile deformations are not large enough to significantly interact with the target response or penetration dynamics.

The advantage of this approach is seen in the foliowing considerations. Computational time is determined by the total number of cells and by the numer of integration cycles in a solution (i.e., the total number of cell-cycles). The number of cycles is proportional to the reciprocal of the time step, which in turn is set by the time it takes the fastest wave (generally a dilatational or sound wave) to cross the smallest cell dimension; $\Delta t_{\max } \propto\left(\frac{\Delta x}{c}\right)_{\min } \cdot$ By describing the projectile as a rigid body, the computational time can be reduced, since:

(1) Larger cells can be used (the small cells required to resolve details of the projectile response are no longer needed). 
(2) Longer time steps can be used (both because of the larger cells, and because of the lower sound speeds usually associated with soft earth materials - as contrasted to projectile materials).

Use of this approach does not preclude analysis of the interior response of the projectile. From the rigidbody solution, stress loading histories imposed on the projectile surface are determined. This information can then be used to "drive" a deformable-body analysis of the stress wave response in the penetrator itself. This coupled technique has been successfully employed on another program.

\subsection{GRID DESIGN}

The computational grid for the rigid-body solution is shown in Figure 17. The contour of the penetrator periphery was resolved with a total of 33 lattice points, spaced at 2 -in. intervals. The computational grid in the target-was divided into two principal regions, as shown in Figure 17. From the problem axis of symmetry out to a radius of 20 in., uniform zoning of $2 \times 2$-in. cells was used. Beyond 20-in. radius, the radial zone width was increased in $10 \%$ steps. The grid extended to a radius of 7 ft. In this outer region, the vertical zone width $\Delta z$. also increased (with increasing depth) in $10 \%$ steps until it reached a maximum value of $10 \Delta z_{0}$. This design for the outer region conserves computational cells, without significantly affecting the solution.

As in the deformable body case, the $\mathrm{K}$-1ine running along the penetrator contour and along the axis of the target was a slide line. Another slide line was used along 


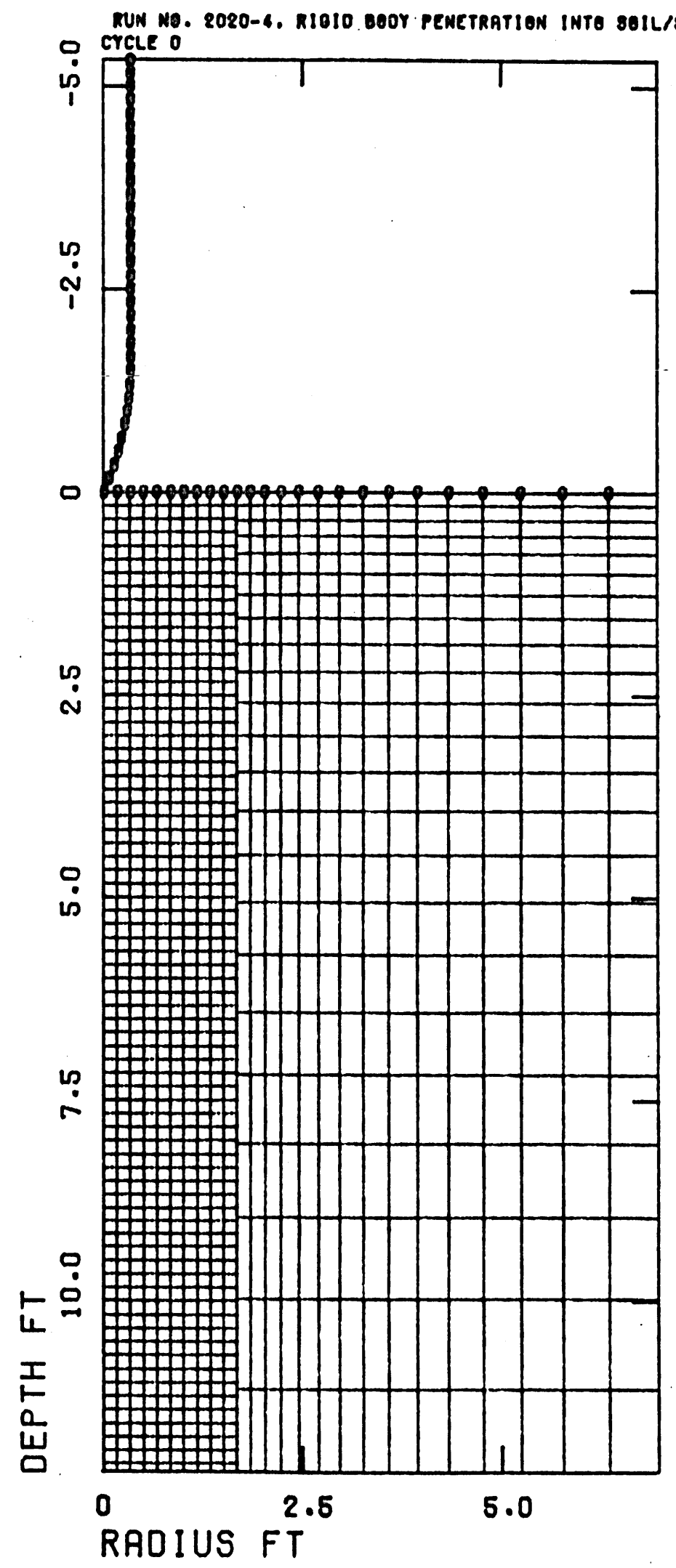

Figure 17. Inftial Grid Configuration for Rigld-Body Solution 
the boundary between the inner and outer grid regions in order to accommodate the differing alignment of the grids on both sides. No significant slippage occurs at this range. This type zoning has been used in Refs. 3 and 4 .

As discussed in Section 4.1, the lattice points at the origin, corresponding to the projectile tip and the soil point at ground zero, were initially decoupled for this rigid-body solution. All the soil points are thus initially at rest.

\subsection{RIGID PROJECTILE SOLUTION RESULTS}

Penetration of the rigid projectile was numerically analyzed through Layer 1 (soil) and for about one projectile length into Layer 2 (shale), to a total depth of 22.3 ft. The grid configuration at an intermediate penetration depth of $11.4 \mathrm{ft}$ is shown in Figure 18. "The "notches" in the open hole behind the projectile are due to periodic deletions of distorted cells after the projectile pasies. Cells in this region no longer have any significant effect on the penetration process, and their removal improves computational efficiency.

At the point in the solution shown in Figure 18 , the wave front in the ground had nearly reached the bottom of the initial computational grid at $12.2 \mathrm{ft}$. (Remember that the projectile velocity was supersonic relative to the dilatational wave velocity in the undisturbed soil.) To extend the grid without increasing the number of cells, a "rolling grid" process was used, wherein the material behind the projectile, from the surface down to $5.7 \mathrm{ft}$ was deleted, and material was added below the initial grid, 


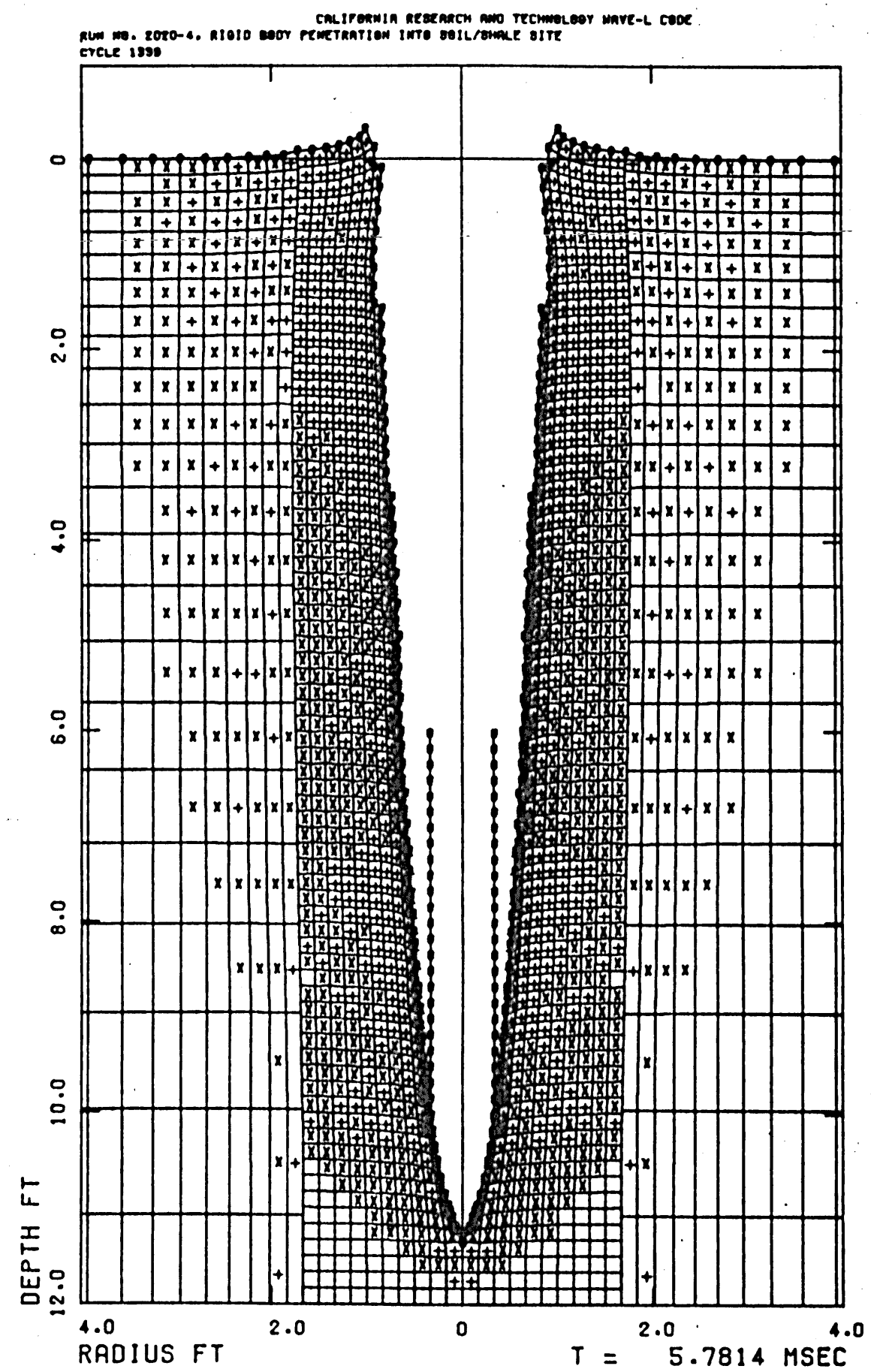

Figure 18. Grid Configuration with Projectile at $11.4 \mathrm{ft}$ Depth Before Rezone 
extending it to a depth of $23.2 \mathrm{ft}$. (Later, the grid was extended again, to $26.5 \mathrm{ft}$ depth.) Pre-deformation of the new grid, wherein the first two columns of cells next to the axis are canted slightly upward, was also introduced at this time. This predeformation improves the orthogonality of cells as they distort while flowing out and around the nose. The pre-deformation is geometric only. The initial physical state of material in the predeformed cells is the same as in normal cells. Figure 19 shows the grid at $11.4 \mathrm{ft}$ penetration after the aforementioned alterations. Note that the grid canting began gradually (starting at $12.2 \mathrm{ft}$ depth), so as to avoid a discontinuity.

Figures 20, 21 and 22 show the grid configuration, particle velocity field, and principal stress field at the end of the solution at $11.6 \mathrm{msec}$, with the projectile nose at $22.3 \mathrm{ft}$ depth. A series of field plots obtained at a sequence of times during the solution is contained in Appendix $C$.

Figure 23 shows the time histories of the total axial force applied to the projectile, and the resultant deceerations. Figure 24 shows axial force/deceleration vs depth of penetration. The discrete nature of the computational grid introduces oscillations in the force/ acceleration traces. As the projectile cuts through the grid, it feels the effects of the load-unload cycle in each cell as that cell slides around the nose surface. In the present problem, the frequency with which the nose encountered new cells was about $12 \mathrm{kHz}$. This frequency is apparent in the force acceleration histories in Figures 


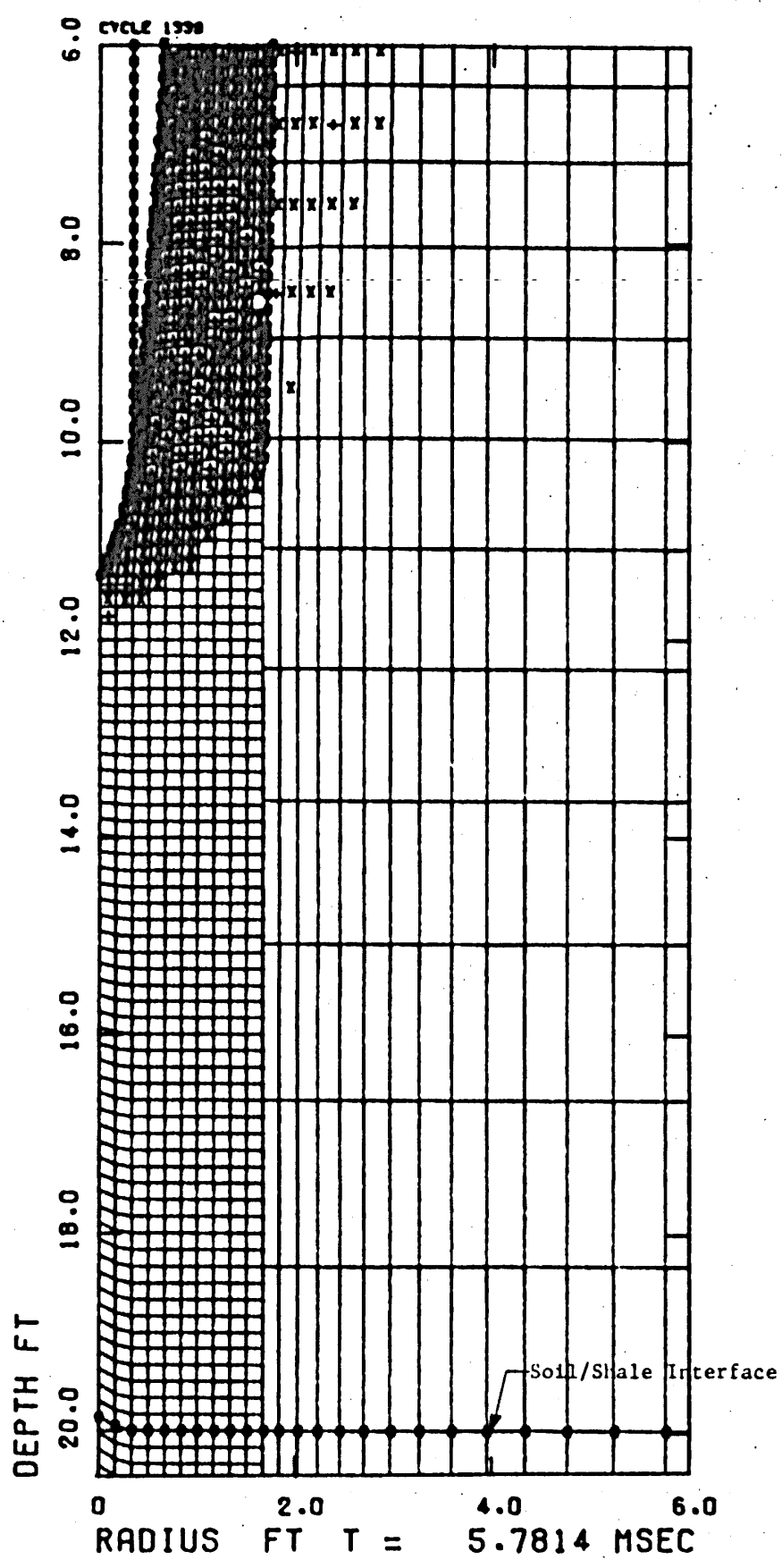

Figure 19. Grid Configuration with Projectile at $11.4 \mathrm{ft}$ Depth after Rezone 


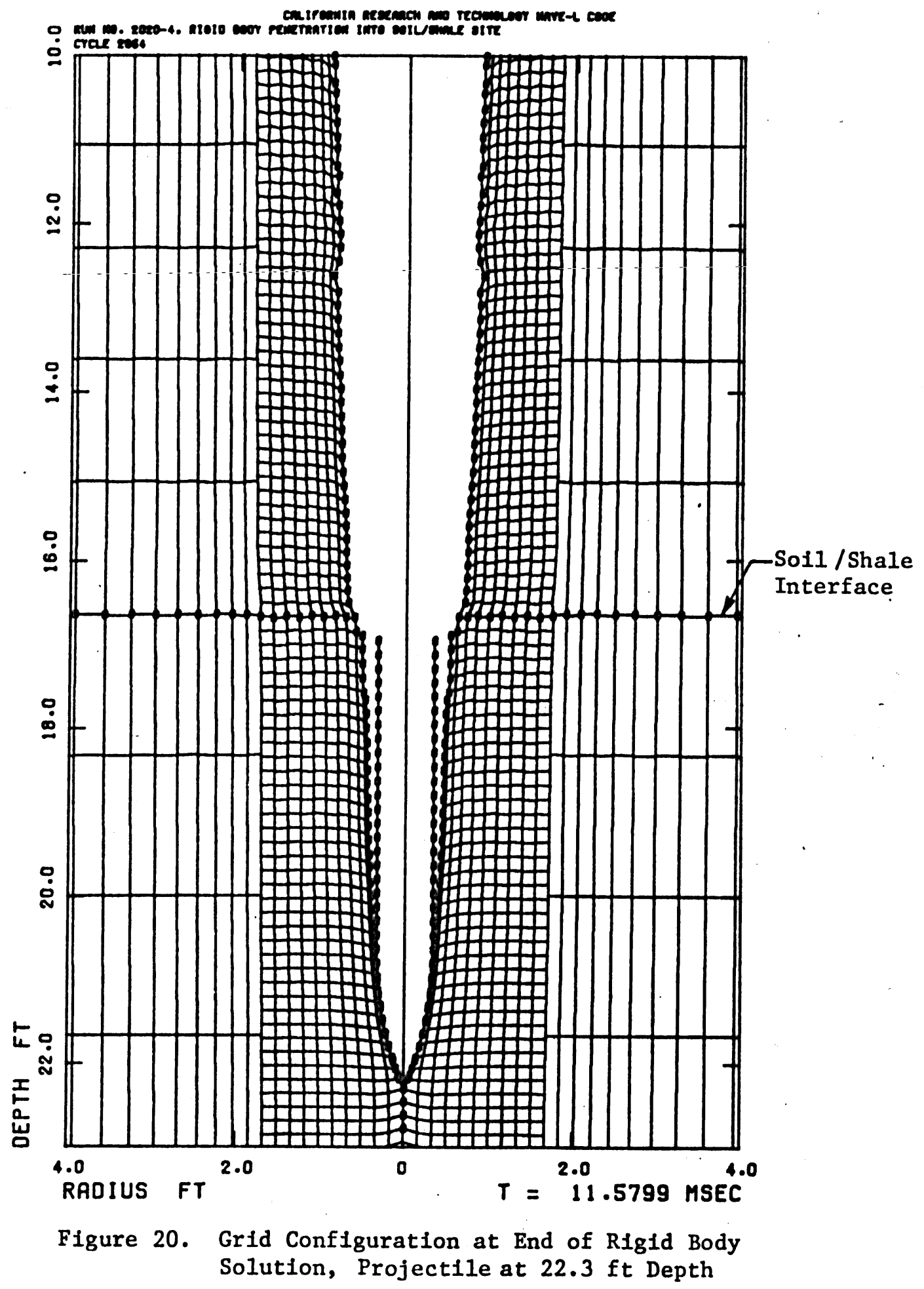




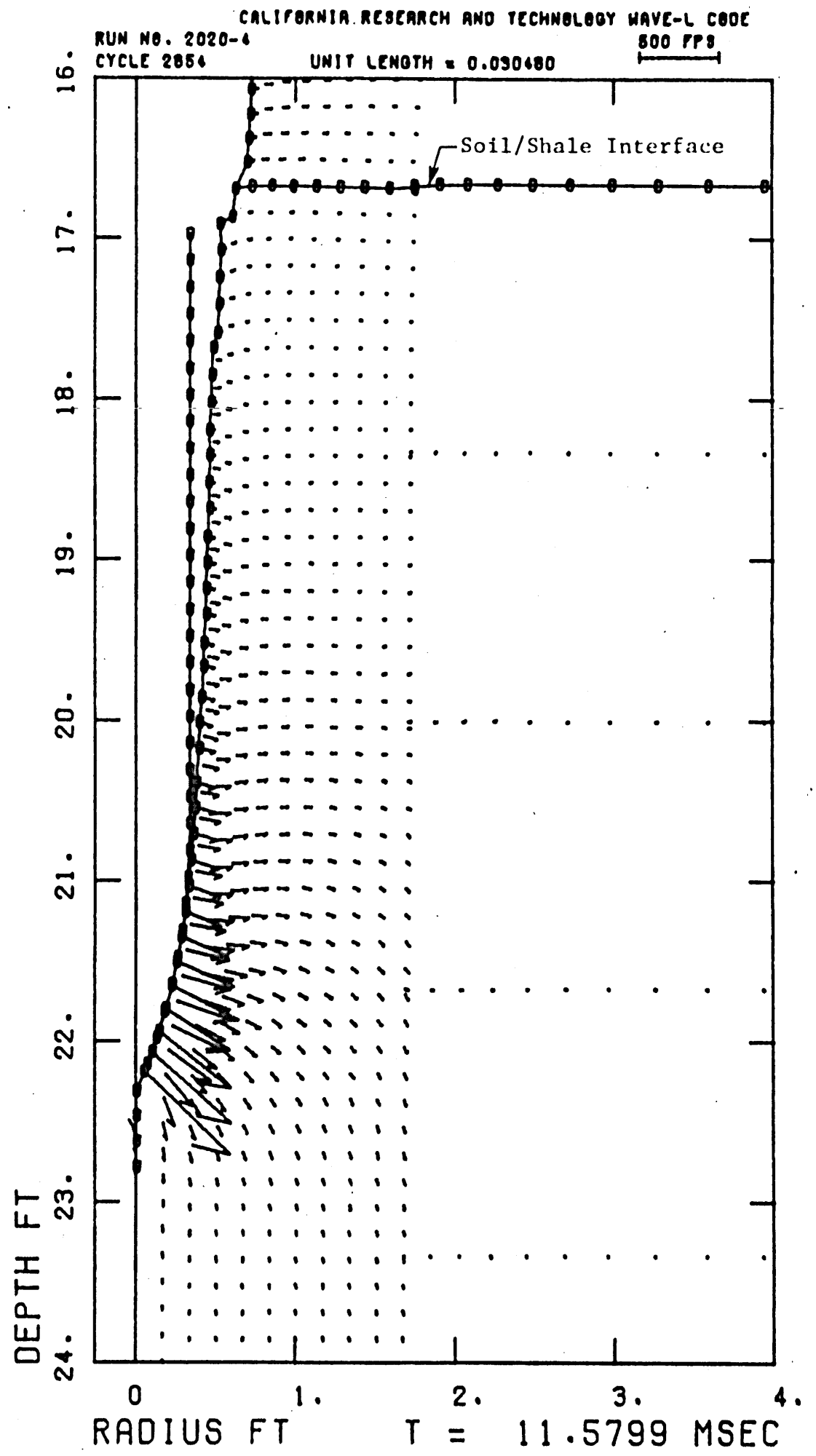

Figure 21. Particle Velocity Field at End of Rigid Body Solution, Projectile at $22.3 \mathrm{ft}$ Depth 


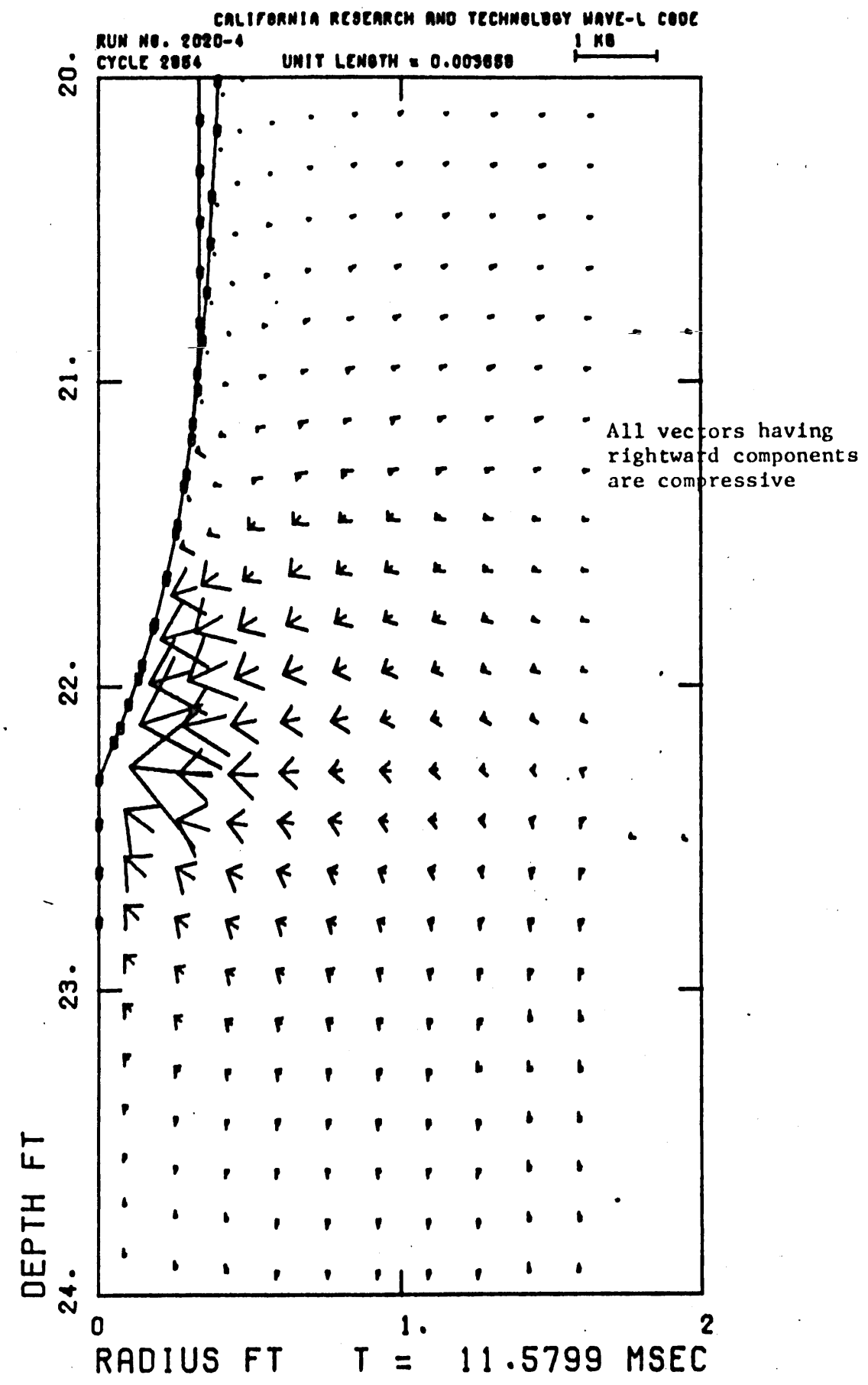

Figure 22. Principal Stress Field at End of Rigld Body Solution, Projectile at $22.3 \mathrm{ft}$ Depth 


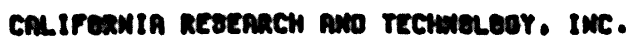

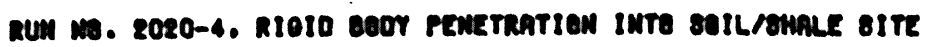

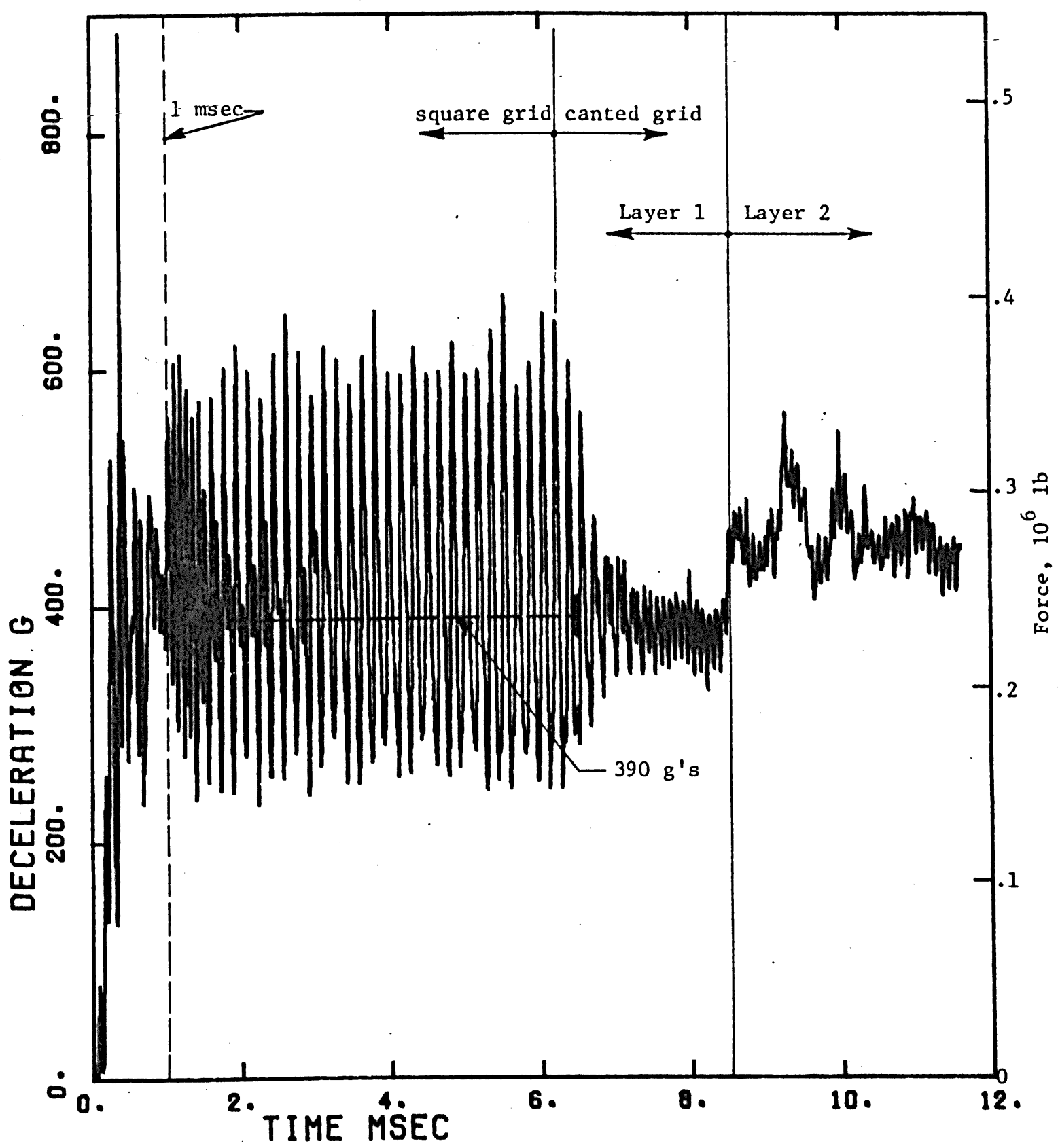

Figure 23 . Axial Force on Penetrator and Deceleration of Profectile vs Time, Rigid Body Solution 
CALIFORNIA REOEARCH ANO TECHNOLOOY, INC.

RUN NO. 2020-4. RIOIO BOOY PENETRATION INTO 8OIL/OHALE 8ITE

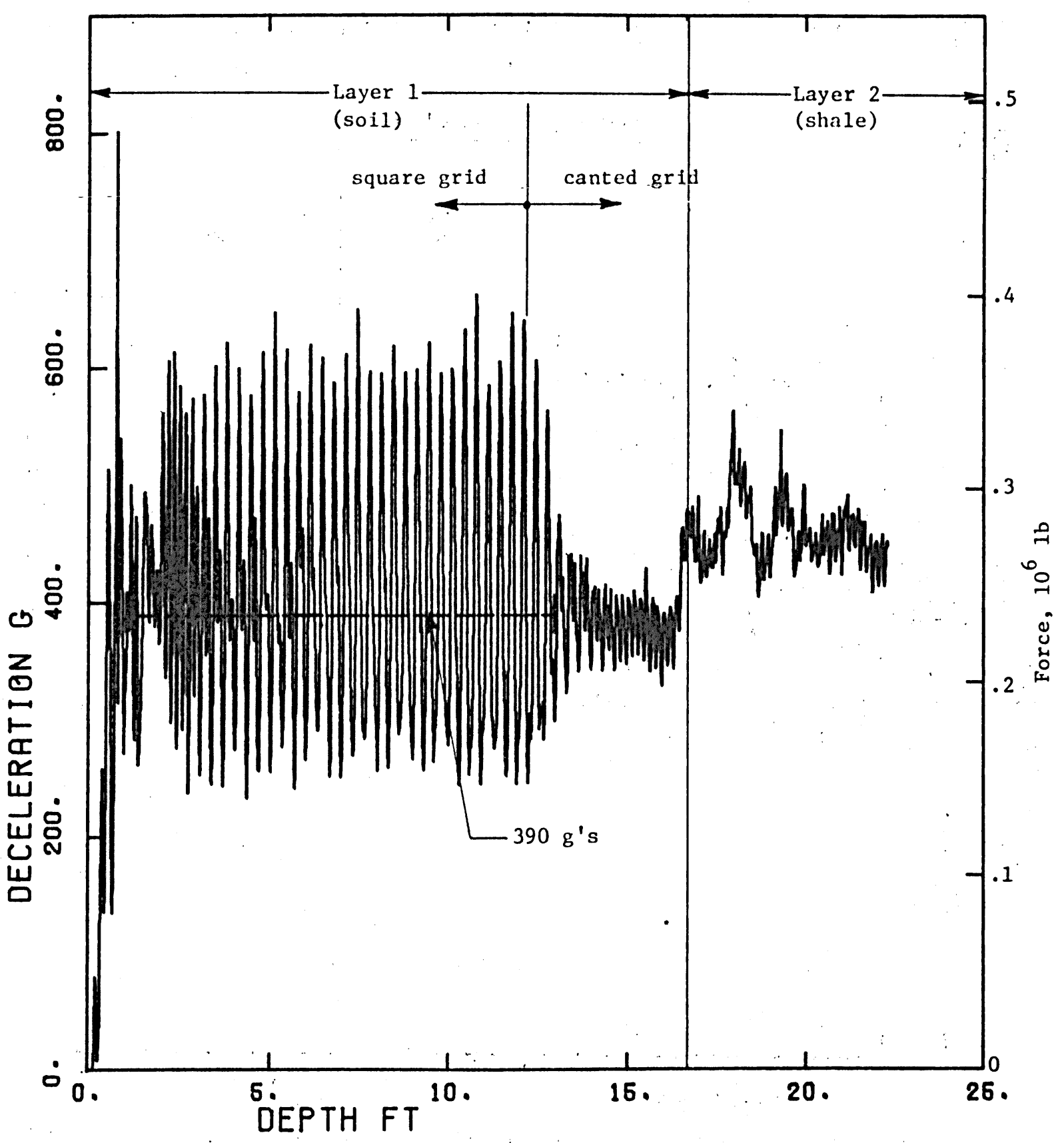

Figure 24. Axial Force on Penetrator and Deceleration of Penetrator vs Depth of Penetration 
23 and 24 at early times and at times after about $7 \mathrm{msec}$ (depths below about $13 \mathrm{ft}$ ).

In the region between about 1 and $6.5 \mathrm{msec}$ (about 2-12 ft depth), regular, much more severe oscillations at about $6 \mathrm{kHz}$ are seen. These were apparently due to synchronous, amplifying interactions between the discrete nature of the grid, the strongly hysteretic nature of the loading-unloading-reloading cycle in the material model, and the gross distortions of the cells moving up the sides of the projectile. The initial loading wave velocity in the Layer 1 model was about $540 \mathrm{fps}$. Unloading (and reloading) always occurred at a much higher velocity; i.e., of the order of 6000-7000 fps. The gross distortion of cells moving out and around the nose caused large loading-unloading oscillations in the few cells which were applying significant axial forces to the nose. The pressure profiles in Figure 25 illustrate such oscillations.

For the reasons cited above, the oscillations in the solution between about $1 \mathrm{msec}$ and $6.5 \mathrm{msec}$ ( $2 \mathrm{ft}$ and $12 \mathrm{ft}$ in depth) are greatly exaggerated and should be disregarded. However, the average deceleration in this region ( $\left.425 \mathrm{~g}^{\prime} \mathrm{s}\right)$ should still be fairly realistic. And indeed it is seen in Figures 23 and 24 that the average deceleration level drops only about $10 \%$ (to about $390 \mathrm{~g}^{\prime} \mathrm{s}$ ) when the severe oscillations go away with the introduction of the predeformed, or canted grid. Is this drop due to the grid geometry change as such, or to the elimination of exaggerated forces in the synchronous oscillations? Apparently the latter: the grid canting was introduced in a very gradual fashion ahead of the projectile, and it required only the very slight 


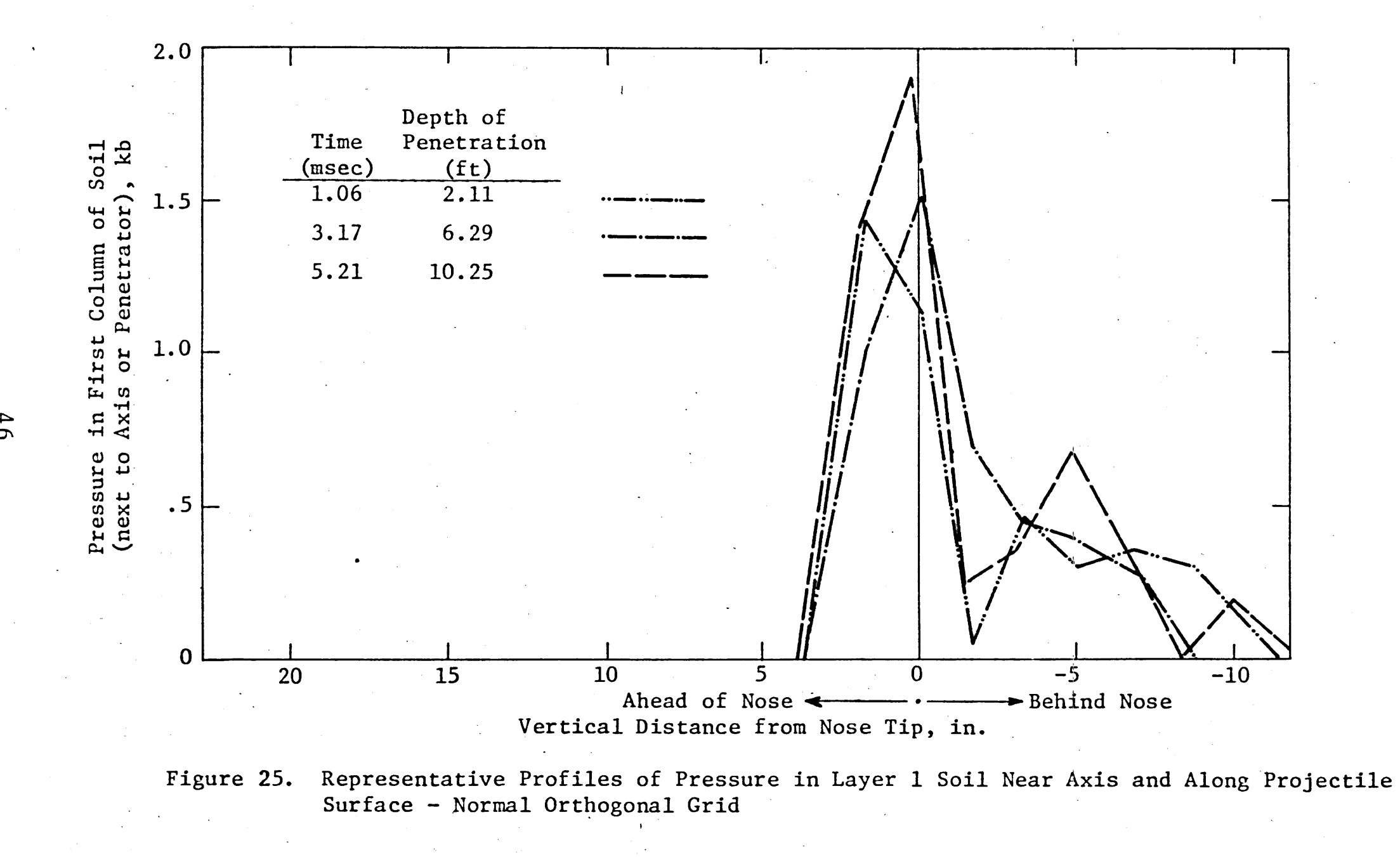


change in grid geometry which occurred in the first few inches below $12.2 \mathrm{ft}$ (see Figure 19) to eliminate the synchronous interactions. As soon as the severe oscillations were reduced, the average deceleration level dropped to $390 \mathrm{~g}^{\prime} \mathrm{s}$. We regard this as the more accurate indication of the deceleration level in Layer 1.

Figure 26 gives pressure profiles in Layer 1 (after introduction of the predeformed grid) and in Layer 2, and illustrates the smoother profiles which were obtained.

The average deceleration increased to about $440 \mathrm{~g}$ 's in the Layer 2 shale. Figures 27 and 28 show the velocity and depth histories. (A constant deceleration of $390 \mathrm{~g}$ 's was assumed between $2 \mathrm{ft}$ and $12 \mathrm{ft}$ depth.) Figúre 29 shows the velocity vs depth. Energy partitioning between the projectile and target during the course of this solution is shown in Figure 30.

Stress, velocity, and displacement histories were obtained at several stations within the target media. These are available to interested readers in unpublished form at WES. ${ }^{9}$ 


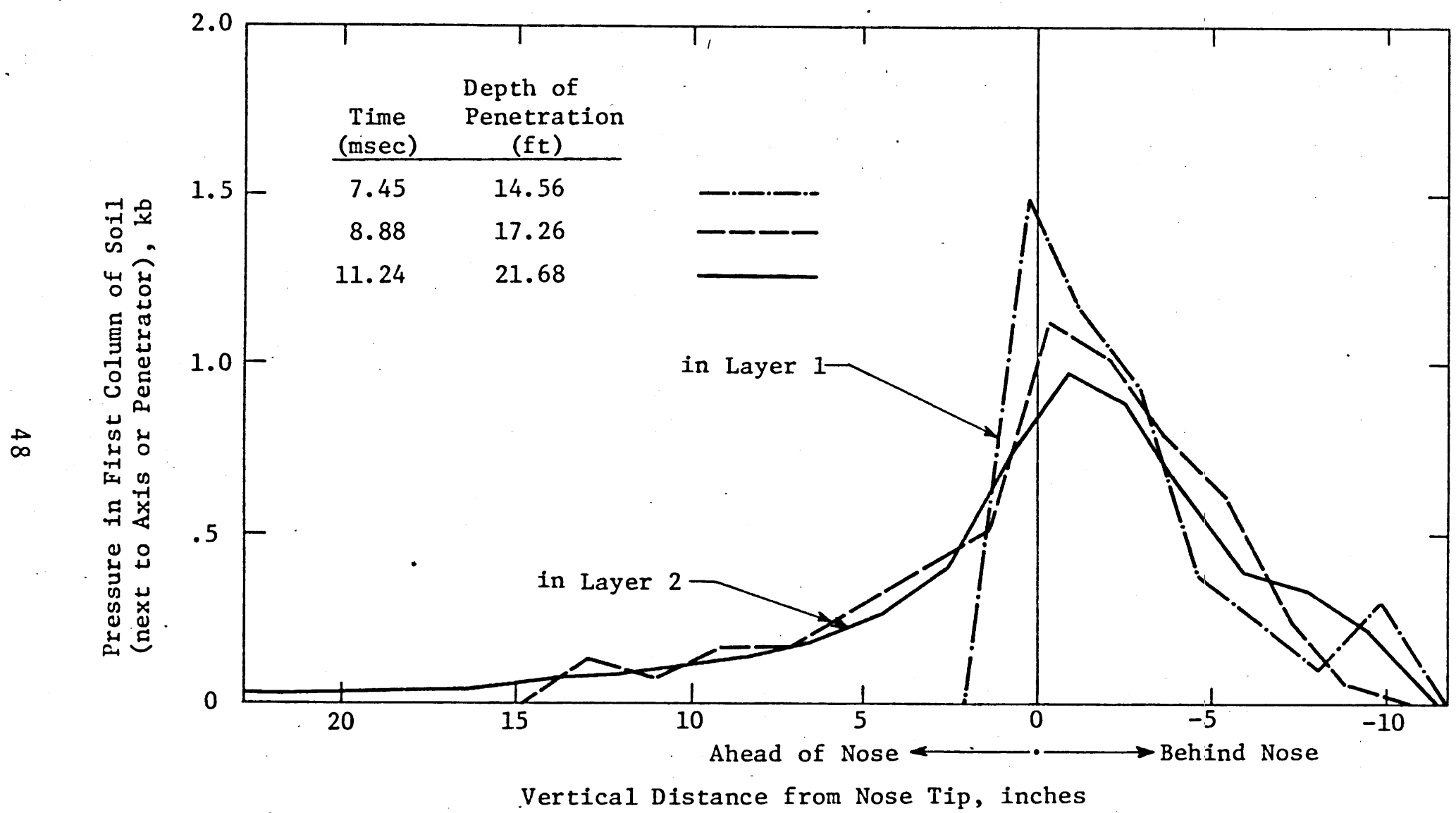

Figure 26. Representative Profiles of Pressure in Layer 1 Soil and in Layer 2 Shale Near Axis and Along Projectile Surface - Canted Grid 


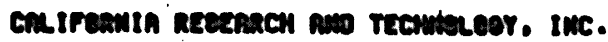

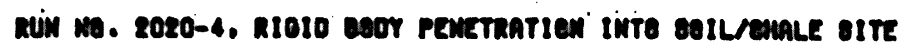

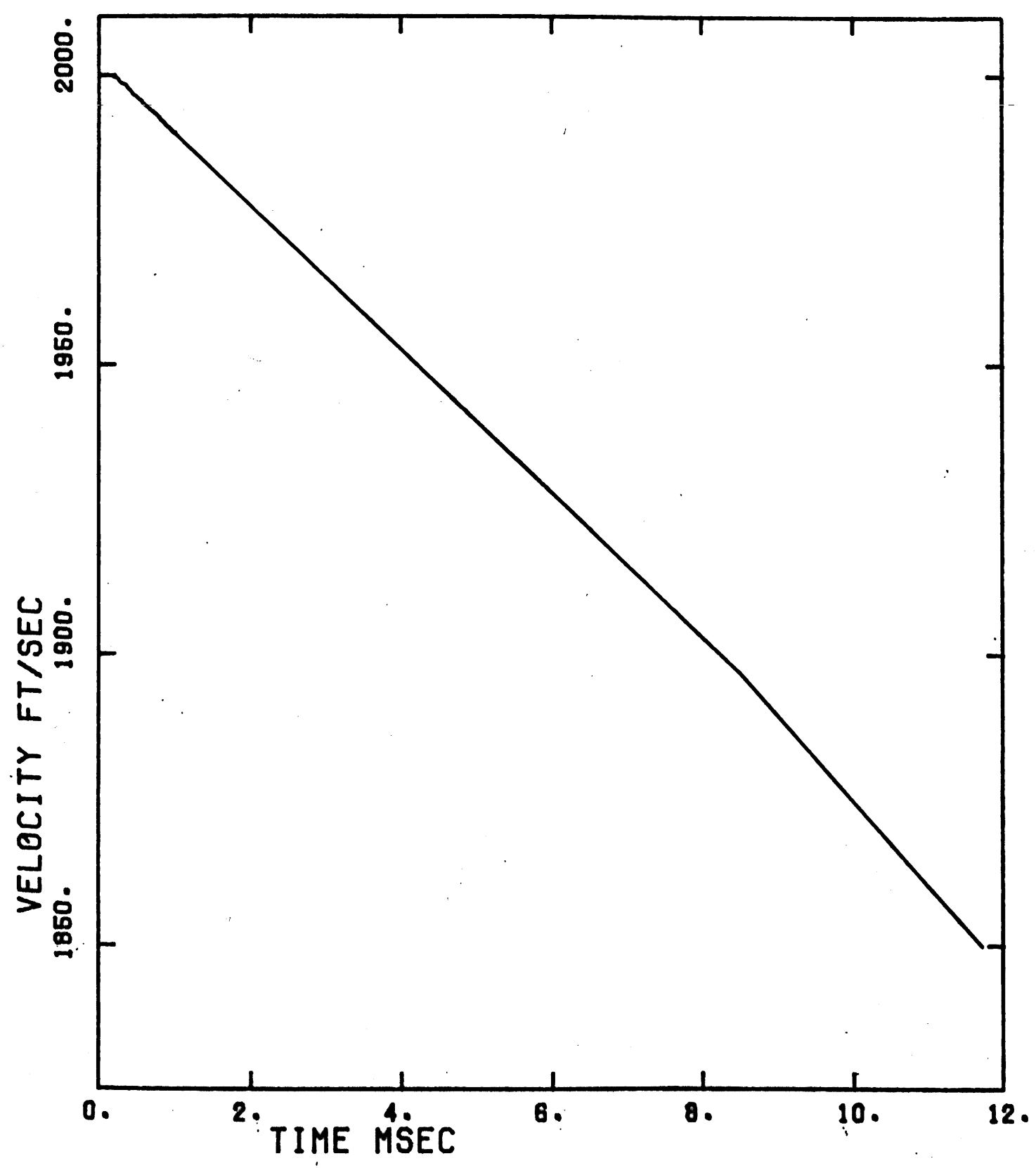

Figure 27. Penetrator Velocity vs Time, Rigid Body Solution 
CaLIFORNIA REOERRCH AMO TECHMOLOOY. INC.

RUN WO. 2020-4. RIOIO BeOY PENETRATION INTO 80IL/OHALE OITE

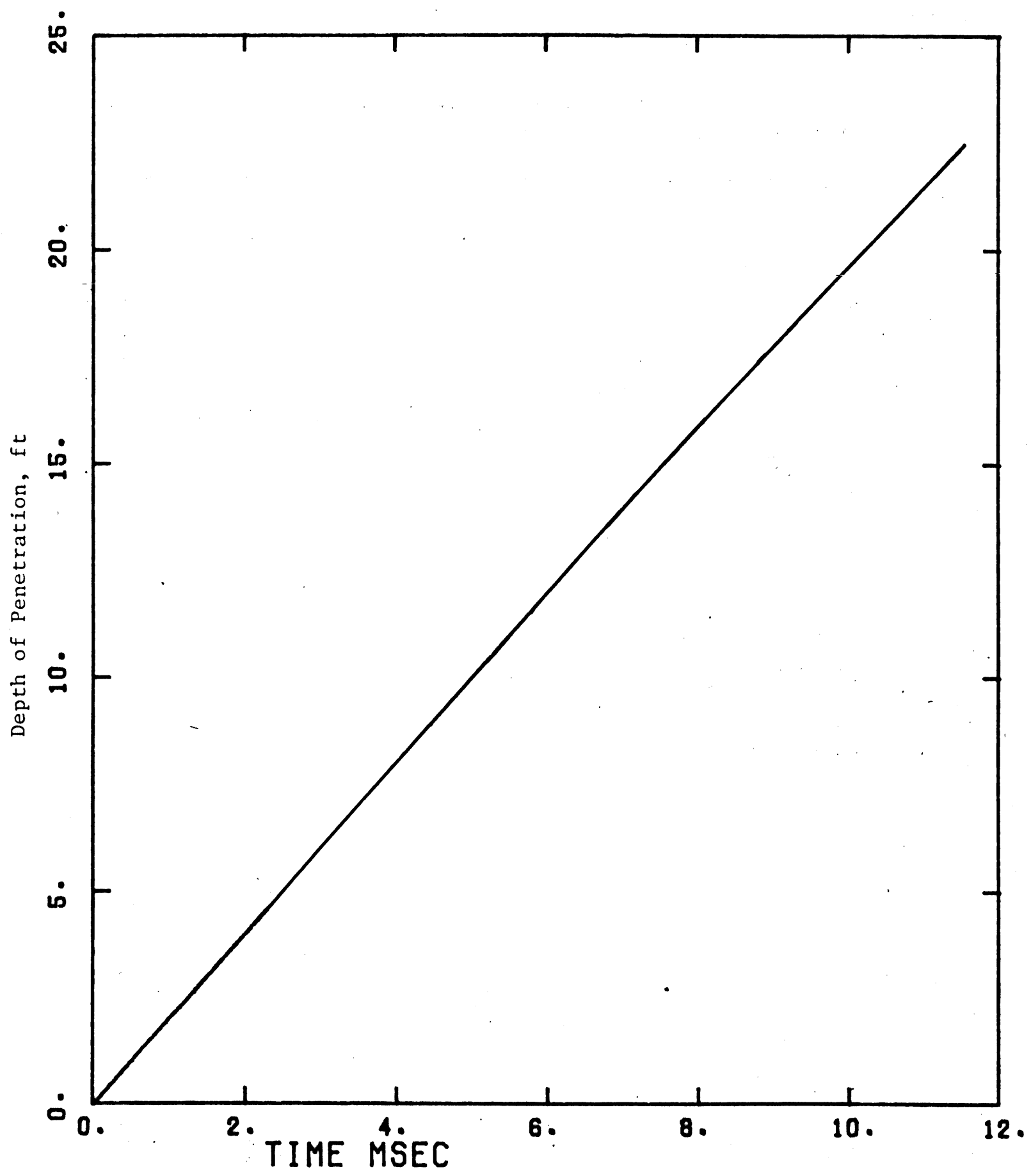

Figure 28. Depth of Penetration vs Time, Rigid-Body Solution 
CALIFORNIA REBEARCH ANO TECHNOLOOY. INC.

RUN NO. 2020-4. RIOIO BOOY PENETRATION INTO 80IL/8HALE SITE

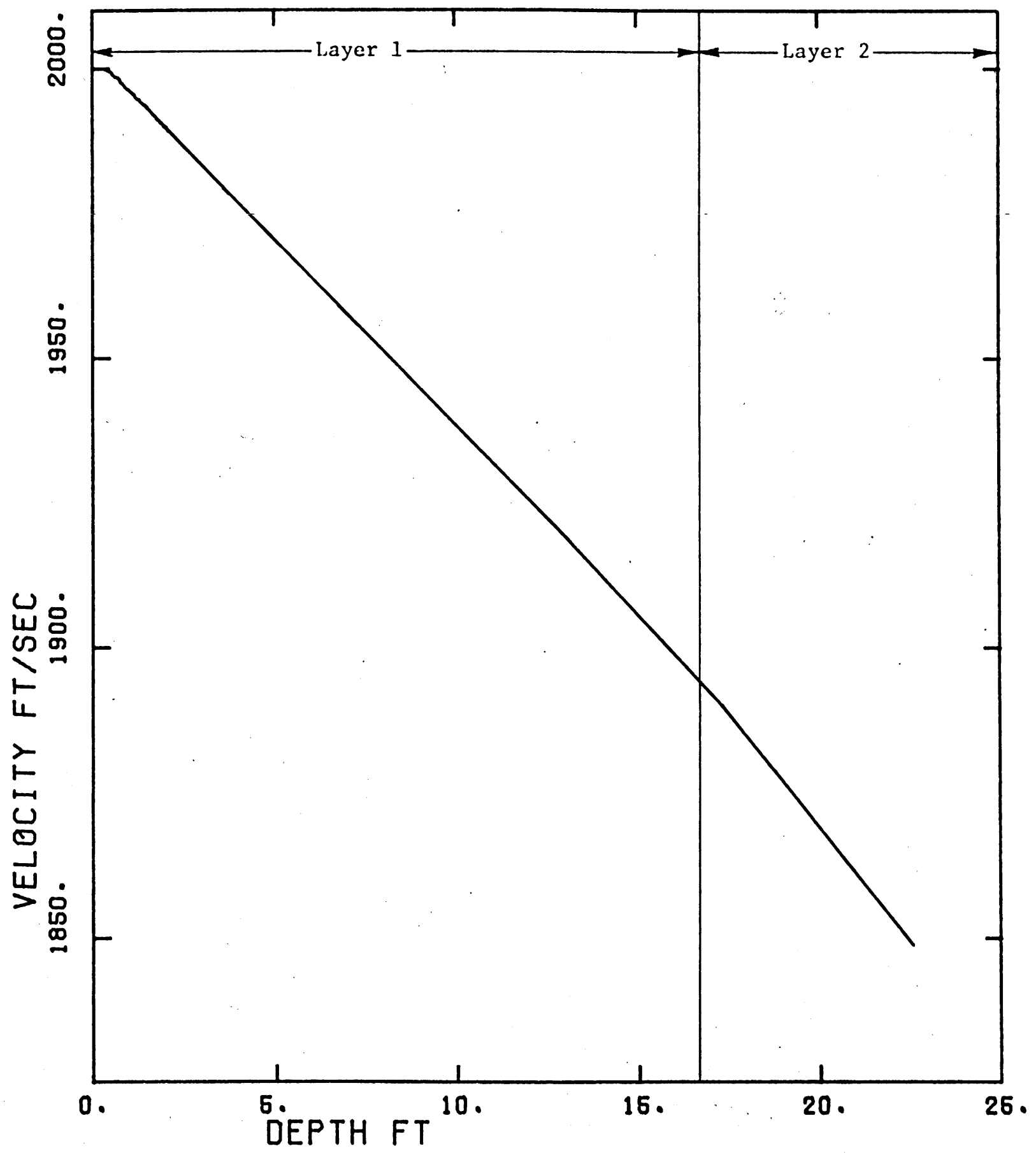

Figure 29. Penetrator Velocity vs Depth of Penetration 


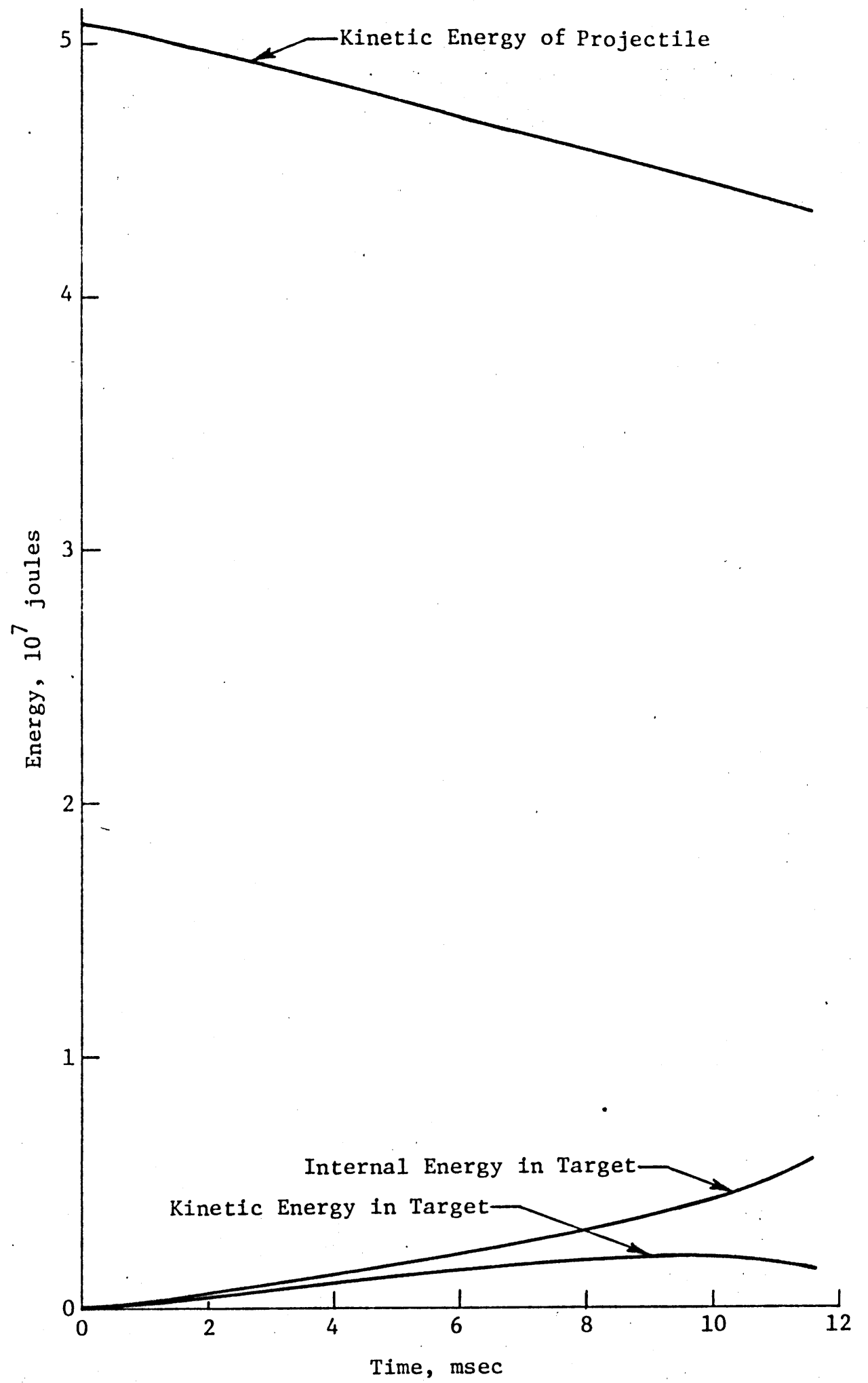

Figure 30. Energy Partition During Rigid Body Projectile Calculation 


\section{SECTION VI}

COMPARISONS OF DEFORMABLE-BODY

AND RIGID-BODY PENETRATIONS

During the time interval covered by both solutions $(t<0.8 \mathrm{msec})$ the solutions for the deformable-body and rigid-body penetrations can be compared. It should be kept in mind that different zoning was used in the two solutions. The basic zoning in the target in the deformable-body analysis was $1 \times 1$ inch, while $2 \times 2$-inch cells were used in the rigid-body solution.

Figure 31 compares the deceleration histories from the deformable-body and rigid-body solutions. Both of these solutions suffered from the excessive distortion of cells moving up the penetrator nose, so the oscillations are large. The frequency of the oscillations in the deformable-body case is about twice that of the rigid-body case. This is consistent with the difference in basic cell sizes in the solutions.

The average level of acceleration is about $585 \mathrm{~g}$ 's in the deformable case, as contrasted to about $400 \mathrm{~g}^{\prime} \mathrm{s}$ in the rigid-body case. Again, this can be attributed to zoning. Stress gradients in the soil near the nose were high. The increased resolution in the deformable case thereby led to higher stresses being applied to the penetrator nose. Figure 32 compares typical radial stress gradients from the two solutions.

The penetrator velocity time histories from the two solutions are shown in Figure 33. At the end of the 

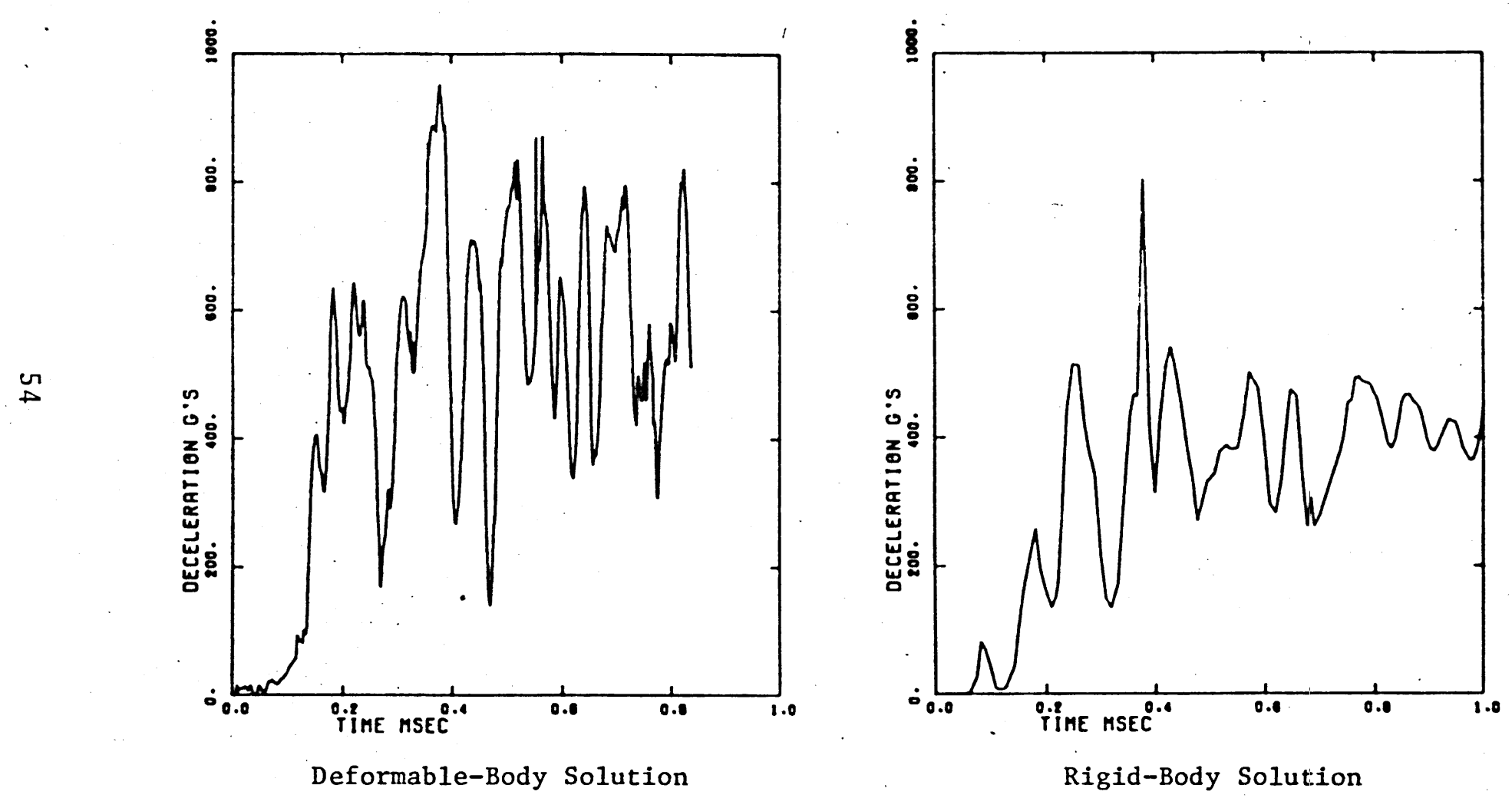

Figure 31. Comparison of. Projectile Deceleration from Deformable-Body and Rigid-Body Solutions 


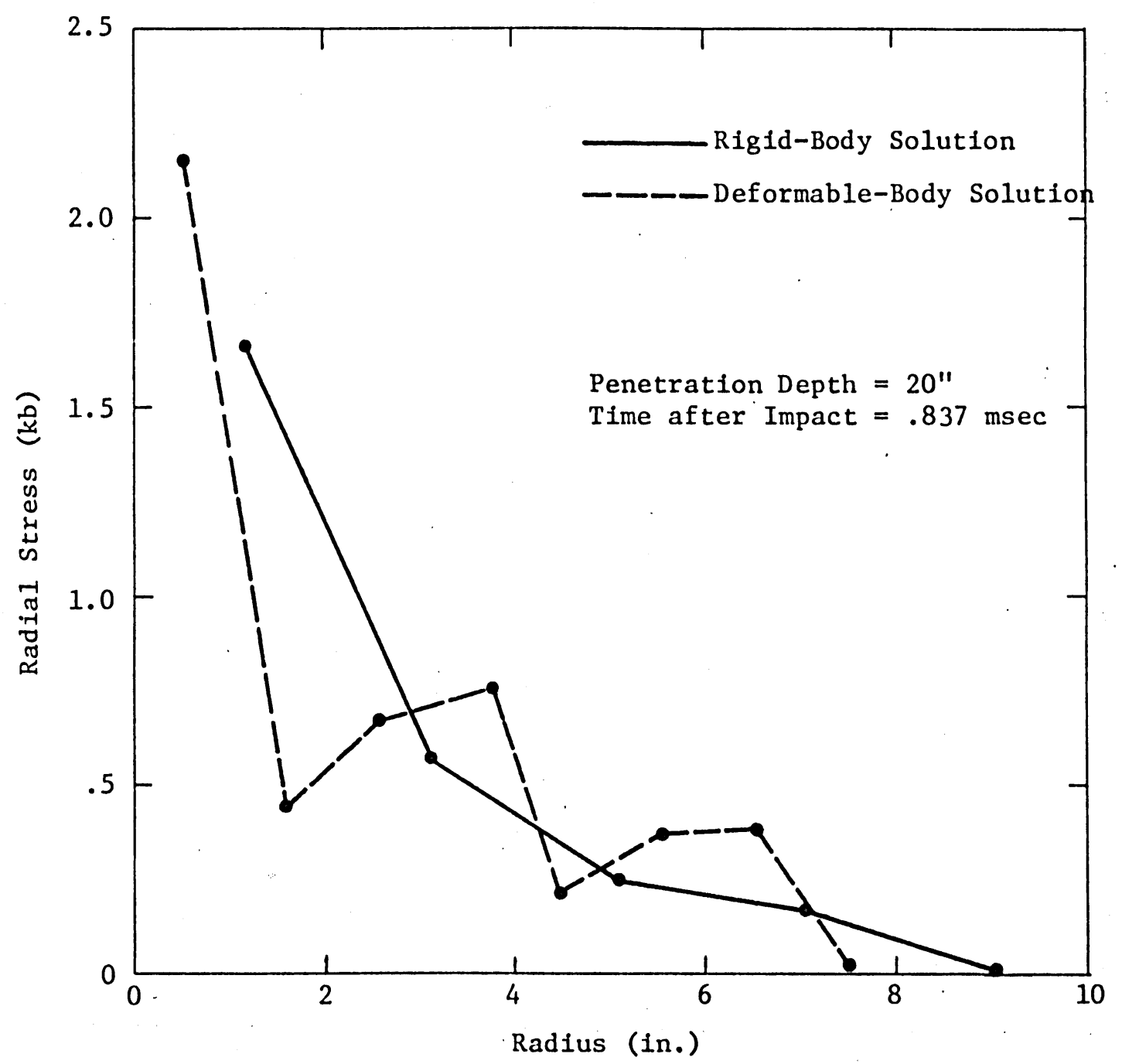

Figure 32. Comparison of Radial Stress Gradient at 20" Depth in Soil from Deformable-Body and Rigid-Body Solutions 


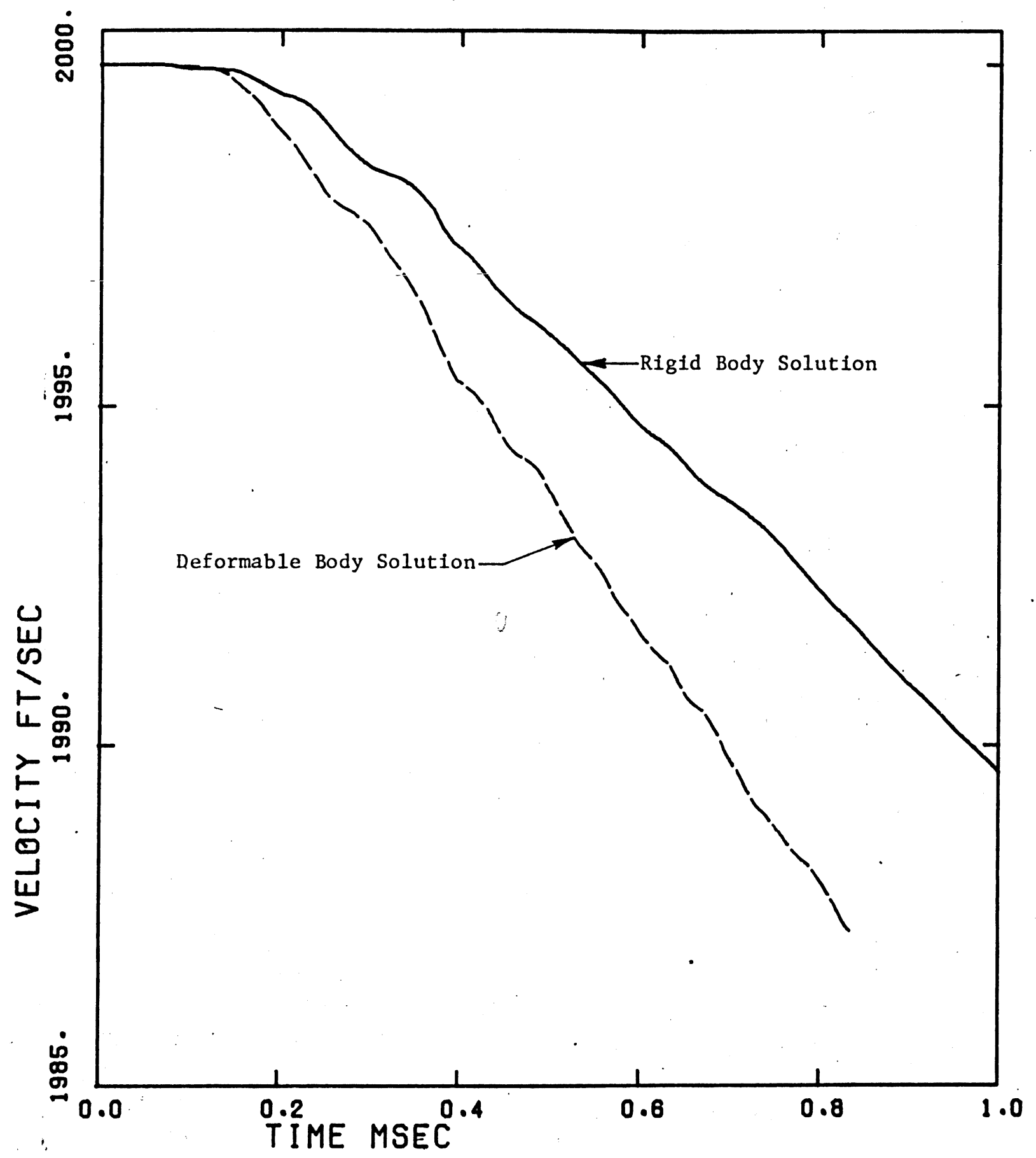

Figure 33. Comparison of Penetrator Velocity from Deformable Body and Rigid Body Solutions 
deformable-body solution $(.84 \mathrm{msec})$, the difference in velocity was about $4.5 \mathrm{fps}$.

To compare the soil response, there were four time history stations positioned at the same locations in the two solutions. These were on the axis at depths of 10 and 20 in. and at $4-$ in. radius at the same depths. Figures 34 and 35 show comparisons of the velocity component traces for the stations at 10 in. depth. These show generally good agreement. Only a very limited comparison could be made for the stations at 20-in. depth, due to the cutoff of the deformable-body solution. These are shown in Figures 36 and 37 . 


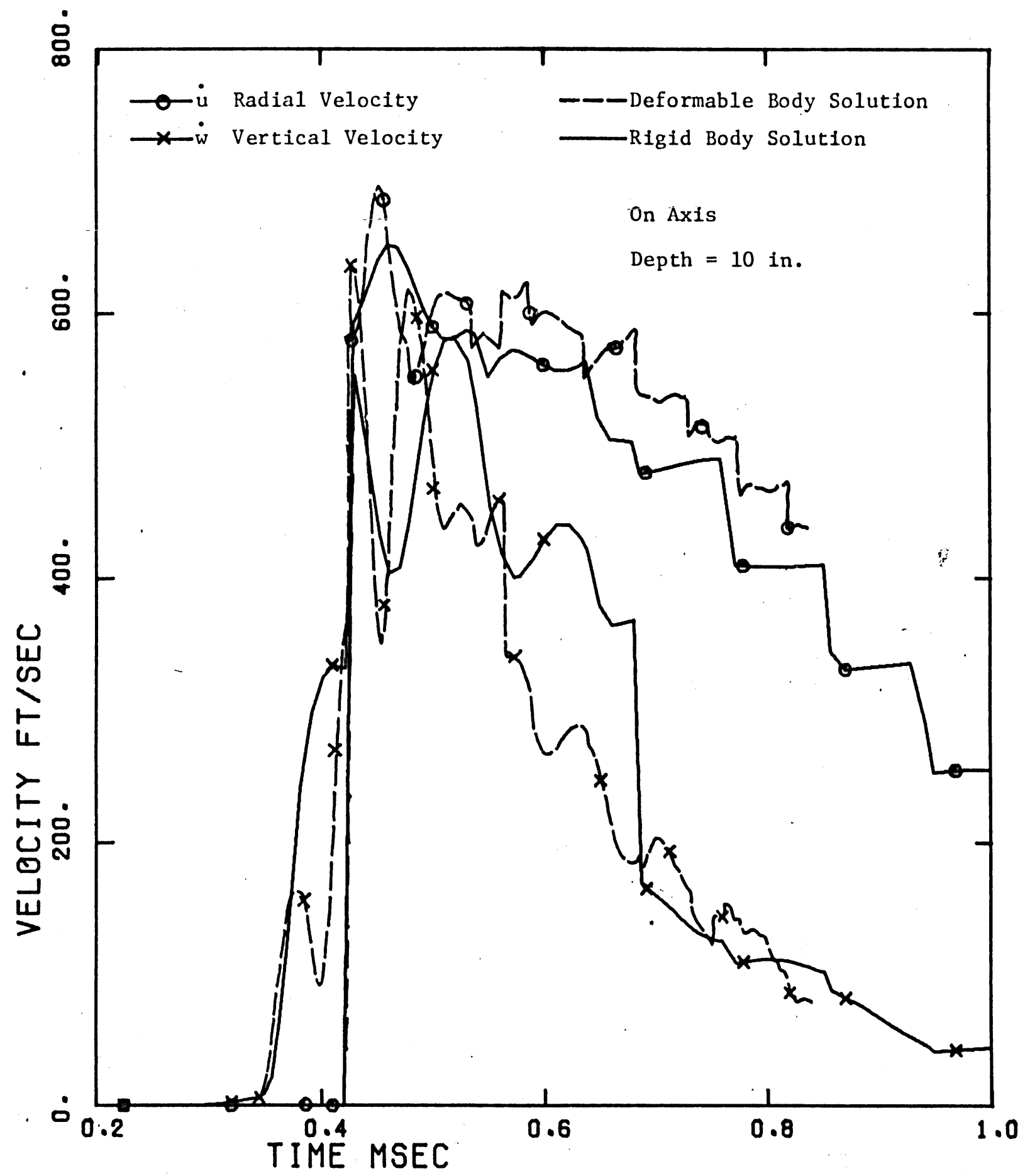

Figure 3.4. Comparison of Velocity Time Histories in Soil from Deformable Body and Rigid Body Solutions 


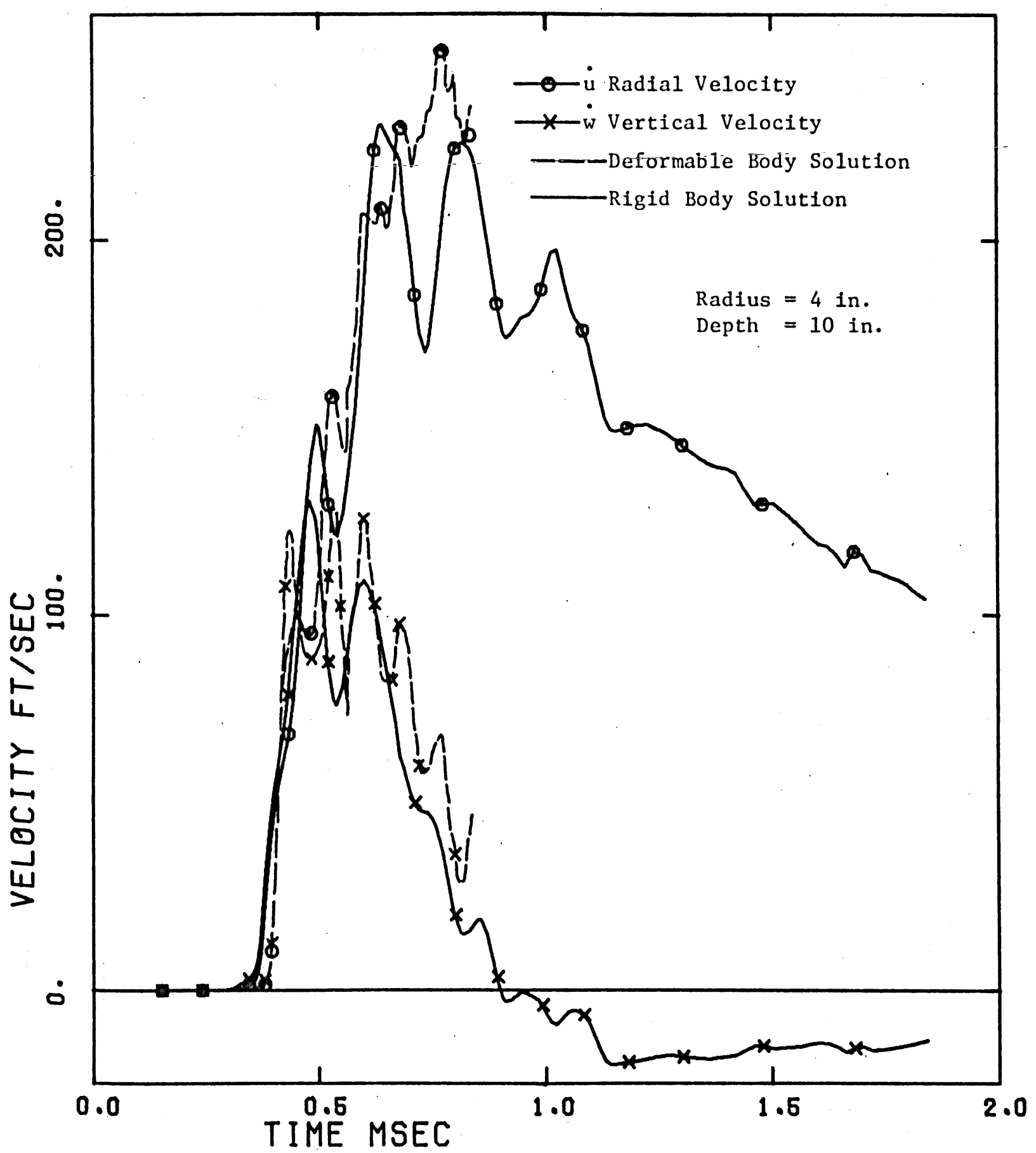

Figure 35. Comparison of Velocity Time Histories in Soil from Deformable Body and Rigid Body Solutions 


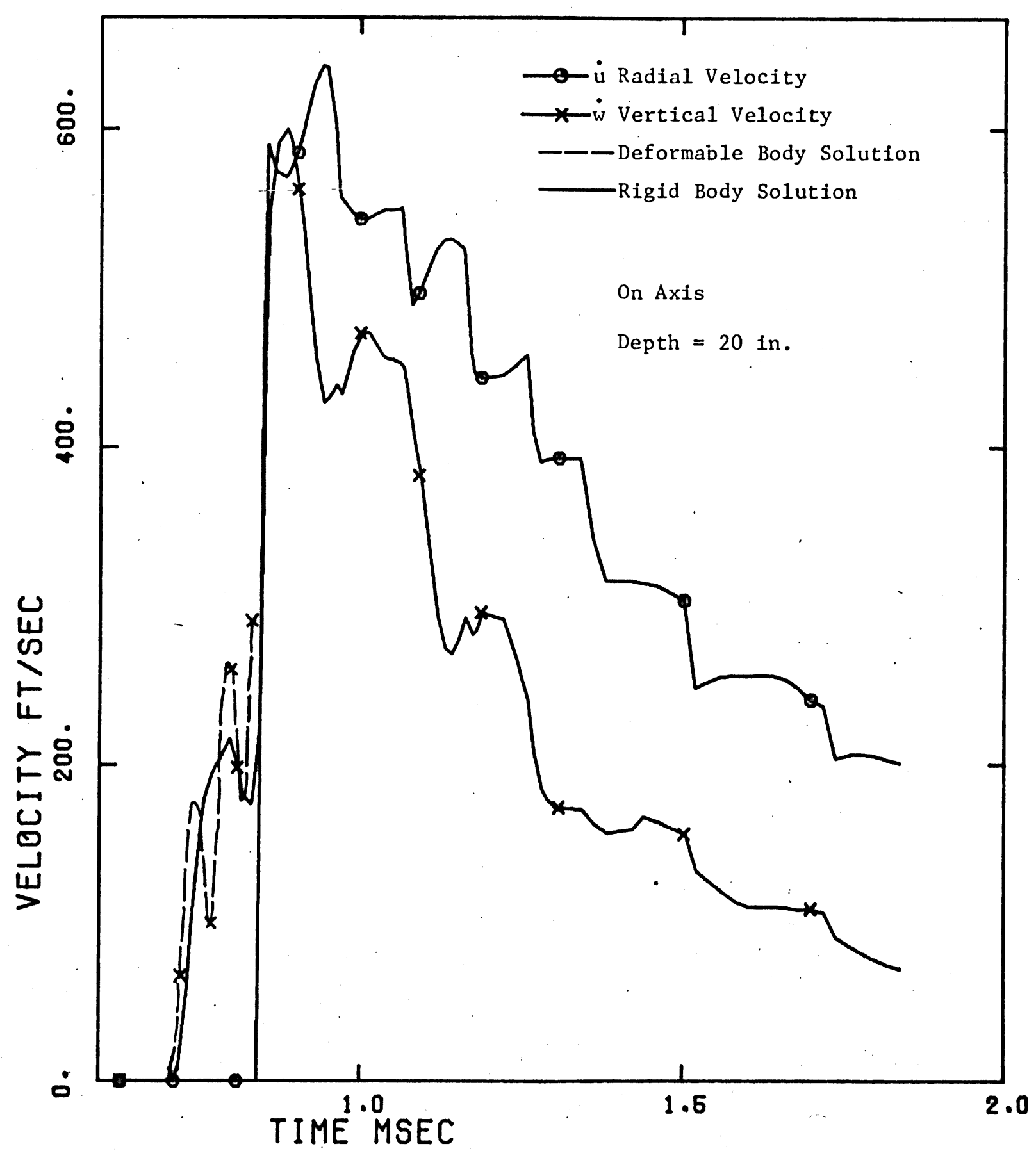

Figure 36. Comparison of Velocity Time Histories from Deformable Body and Rigld Body Solutions 


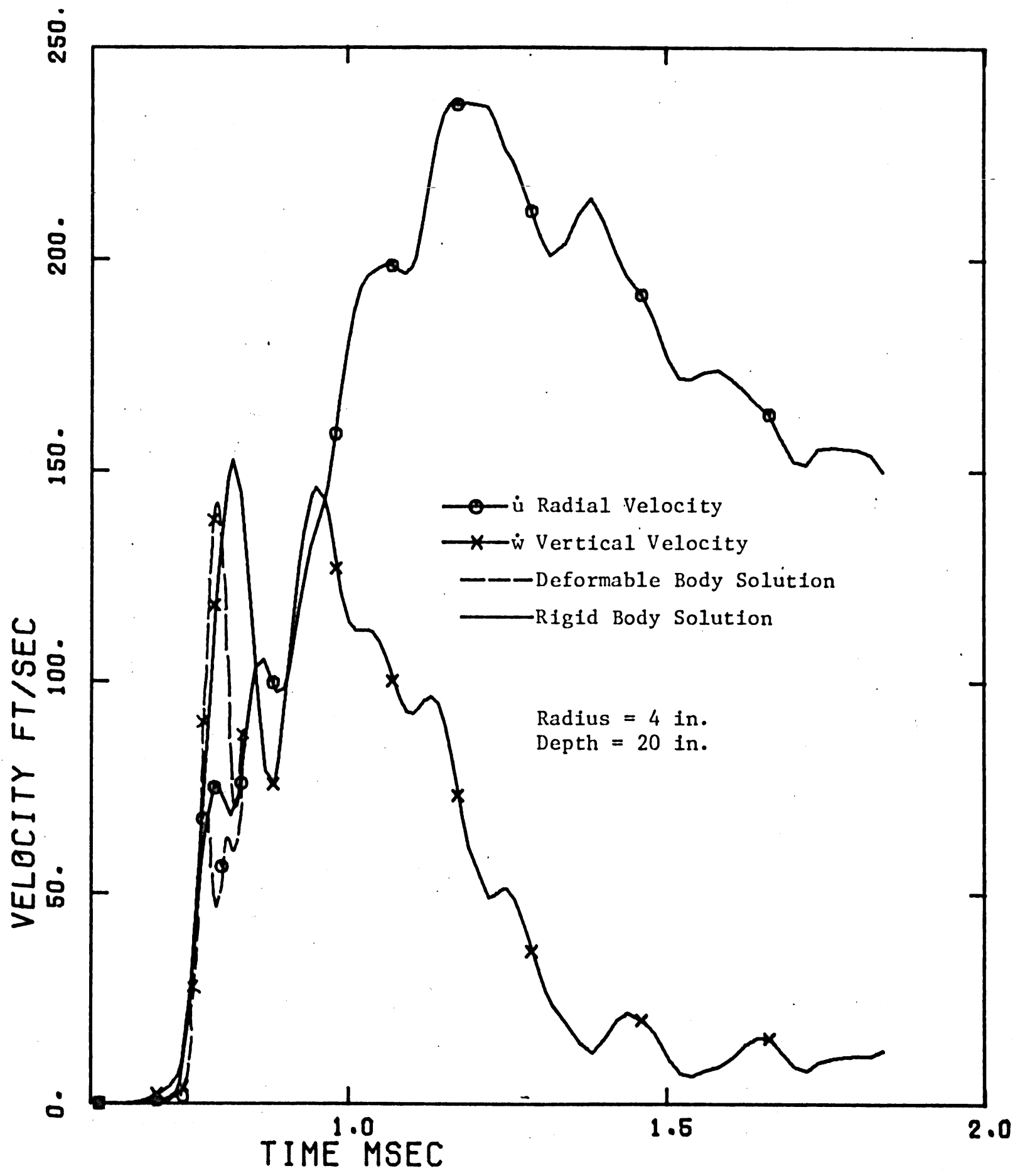

Figure 37. Comparison of Velocity Time Histories from Deformable Body and Rigid Body Solutions 


\section{SECTION VII}

\section{CONCLUSIONS AND RECOMMENDATIONS}

The results of this study provide additional information with which to evaluate the role of finite-difference code calculations of earth penetration problems. The finite-difference approach appears to be very useful for analysis of certain aspects of these problems. It is unsuitable, or at least inefficient, for others.

\subsection{RIGID-BODY PENETRATIONS}

Successful penetrator designs will generally experience only elastic deformations. (An exception might be a design with a sacrificial nose section.) It is therefore reasonable, and efficient, to analyze penetration by treating the projectile as a rigid body. Such analyses provide a practical method for:

o Examining the interactions between projectile shape, basic target media properties, and impact velocity, (thereby providing analytical guidance for designing and evaluating improved projectile designs), and

o Determining the external loading distributions on the projectile (thereby providing bases for analyzing the projectile response and internal design environment).

These types of analyses do not require computer solutions of complete deep penetration problems. They require only that the projectile travel far enough in a given 
target medium to reach quasi-steady-state conditions. Such analyses should therefore be confined to those portions of a penetration event where the loading on the projectile is most severe, or where the loading changes significantly (e.g., during initial impact and embedment of the nose into the surface layer, and during passage between different geologic layers).

There are a number of improvements. which should be made in the rigid-body analysis technique. These include efficient rezoning procedures to correct grid distortion in the target medium near the penetrator surface, and the establishment of minimum zoning criteria to ensure reasonably accurate solutions. Both of these steps are being undertaken in a current program.

Because of the long computing times required, it is probably inefficient to use a finite-difference code to analyze complete deep penetration problems (i.e., from. impact until the projectile comes to rest).

\subsection{PROJECTILE RESPONSE}

To analyze the response of the projectile, a solution of the penetration may be performed in which the projectile is treated as a deformable-body (such as was done in this study). However, finite-difference solutions of this type, in which the projectile deformation and the target deformation are treated together, are time consuming due to the markedly different character of the projectile and target responses. Good spatial resolution is needed in the projectile in order to resolve structural details, and the wave speeds in typical projectile materials are relatively 
high. These factors dictate small integration times steps. On the other hand, coarser spatial resolution and lower wave speeds in the taget media will normally permit much longer time steps.

Because of these differences in the integration time step and in the magnitudes of the distortions involved, it is more efficient to perform separate but coupled analyses of target penetration and of penetrator response. Thus, a rigid-body analysis can first be performed of the penetration in the target media. From this rigid-body solution, the penetration history and force-loading history imposed on the projectile surface is determined. This information can then be used to drive a deformable-body analysis of the stress wave response in the projectile itself.

Performing separate computations also allows the choice of making either a finite-difference or a finite-element code analysis of the projectile response. So long as the strains are small and the internal structure can be acceptably modeled, the finite-element method may be more efficient.

\subsection{NUMERICAL OSCILLATIONS}

Severe numerical oscillations were experienced in the force applied to the projectile during the deformable-body solution and during part of the rigid-body solution. These are attributed to reinforcing synchronous interactions between the deformed finite computational grid and the strongly hysteretic nature of the soil model. This problem (which has been far less severe in other penetration analyses we have performed in 1 ess hysteretic media) ${ }^{4,5}$ was alleviated by 
using a slightly canted, or pre-deformed grid. In strongly hysteretic media, considerable care needs to be taken in modeling the collapse of the porosity and the unloading behavior experienced in material moving around a projectile nose. 


\section{REFERENCES}

1. M. L. Wilkins et al, "Progress Report on Light Armor Program", UCRL 50284, 1967

2a. M. H. Wagner, "Analytical Study of Penetration Mechanics", Rpt. 3030-2020 FR, Shock Hydrodynamics, Inc., May 1969

2b. M. H. Wagner, "Analytical studies of Projectile Design and Performance", Rpt. 7584-06, Shock Hydrodynamics, Inc., August 1971

3. L. Thigpen, "Penetration of Projectiles into Continuous Earth Media", SC-RR-72 0204, Sandia Laboratories, May 1972

4. M. H. Wagner, K. N. Kreyenhagen, and W. S. Goerke, "Numerical Ana1ysis of DNA Earth Penetrator Experiment at DRES", DNA 3537F (CRT Report 2050-2), October 1974

5. Y. M. Ito, K. N. Kreyenhagen, G. E. Eggum, ánd W. S. Goerke, "Analysis of Dynamic Stresses Within a Terminal Delivery Vehicle During Penetration of a Hard Earth Target":, CRT Report 2060-1 (in publication by WES)

6. M.'L. Wilkins, "Calculation of Elastic-Plastic Flow", Lawrence Livermore Laboratory, UCRL-7322, Rev. 1, January 1969

7. D. K. Butler, U. S. Army Waterways Experiment Station, Vicksburg, Mississippi, personal communication

8. R. Hill, Mathematical Theory of Plasticity, Oxford, 1950

9. "Time Histories of Stresses, Velocities, and Displacements", (unpublished) Contract DACA39-74-C-0007, California Research \& Technology, Inc., May 1975 
APPENDIX A

MATERIAL MODELS

Material models for the two site layers were developed, based on the set of representative soil properties furnished by WES. Hysteretic elastic-ideally plastic models using a prandt-Reuss (non-associated) flow rule were employed.

A non-hysteretic elastic-perfectly plastic model was used for the steel projectile.

\section{A. 1 LAYER 1}

\section{A.1.1. Equation of State}

The pressure is given by a Mie-Grüneisen equation:

$$
P=F(\mu)+\gamma \rho e
$$

where

$$
\begin{aligned}
& \mathrm{e}=\text { specific internal energy } \\
& \mathrm{P}=\text { pressure } \\
& \rho=\text { density } \\
& \mu=\frac{\rho}{\rho_{0}}-1 \\
& \gamma=\text { Grüneisen constant }
\end{aligned}
$$

The hydrostat, $F(\mu)$, is specified through a hysteretic model.

\section{A.1.2 Loading Hydrostat}

The loading hydrostat up to the point of void closure, $\mu_{c}$, was fit from $P-\mu$ data deduced from the loading curves of stress vs strain and stress difference vs 
pressure. Beyond void closure, a well-behaved asymptoticform is employed.

$$
\begin{array}{rlrl}
F=A \mu & \mu \leq 0 \\
F=A \mu+B\left[\exp \left(\alpha \mu^{\beta}\right)-1 \cdot\right] & & 0<\mu \leq \mu_{c} \\
F= & F_{c}+K_{\max }\left(\mu-\mu_{c}\right) & \\
& -\left(K_{\max }-K_{c}\right) \mu *\left[1-\exp \frac{\mu_{c}-\mu}{\mu^{*}}\right] & \mu>\mu_{c}
\end{array}
$$

The values of the constants are:

$$
\begin{aligned}
\mathrm{A} & =2.9211 \times 10^{-4} \mathrm{Mb} \\
\mathrm{B} & =2.3003 \times 10^{-9} \mathrm{Mb} \\
\mathrm{F}_{\mathrm{C}} & =2.0059 \times 10^{-4} \mathrm{Mb} \\
\gamma & =1 . \\
\mathrm{K}_{\mathrm{C}} & =.046131 \mathrm{Mb}
\end{aligned}
$$

$$
\begin{aligned}
\mathrm{K}_{\max }= & .68946 \mathrm{Mb}^{\circ} \\
\alpha= & 302.27 \\
\beta= & 1.1 \\
\mu_{c}= & .0504 \\
\mu^{*}= & .25 \\
\rho_{0}= & 1.9222 \mathrm{gm} / \mathrm{cm}^{3} \\
& \left(1201 \mathrm{~b} / \mathrm{ft}^{3}\right)
\end{aligned}
$$

\section{A.1.3 Shear Modulus - Loading}

The shear modulus function for loading was determined from a graphical assessment of the variation of Poisson's ratio along the unloading stress path (stress difference vs pressure) and the bulk modulus (as derived from the hydrostat equations). A maximum value equal to the unloading shear modulus was imposed to prevent energy generation. 


$$
G_{\text {load }}=\operatorname{Min}\left[\frac{3 B(1-2 v)}{2(1+v)}, G_{\text {unload }}\right]
$$

where

$$
\begin{aligned}
& B=(\mu+1) \frac{\mathrm{dF}_{10 \mathrm{~d}}}{\mathrm{d \mu}}(\mu) \\
& \nu=.5-.25 \exp \left(\frac{-\mu}{.033}\right)
\end{aligned}
$$

Initial values of the bulk modulus, the shear modulus, the constrained modulus, Poisson's ratio, and the dilatational sound speed from the model are:

$$
\begin{array}{ll}
B_{0}=4,237 \text { psi } & \nu_{0}=.25 \\
G_{0}=2,542 \text { psi } & c_{0}=542.6 \mathrm{ft} / \mathrm{sec} \\
M_{0}=7,626 \mathrm{psi} &
\end{array}
$$

\section{A.1.4 Unloading Mode1}

In the hysteretic region, $\mu<\mu_{c}$, a model giving a fan of constant slope $\mathrm{P}-\mu$ unloading paths was used (slopes are a function of $\mu_{\max }$ ):

$$
\begin{array}{ll}
F=F_{\max }+K\left(\mu-\mu_{\max }\right) & \mu_{\max }<\mu_{c} \\
F=F_{c}+K_{c}\left(\mu-\mu_{c}\right) & \mu_{\max } \geq \mu_{c}
\end{array}
$$

The unloading bulk modulus varied from a minimum of $100 \mathrm{ksi}$ to a maximum of $702.8 \mathrm{ksi}$. (The maximum corresponds to the bulk modulus for loading at void closure.) The unloading bulk 
modulus was made a function of the maximum compression, $\mu_{\max }$. A constant value for the unloading shear modulus was assumed. The initial Poisson's ratio for unloading was the same as for loading, $\nu_{0}=.25$, giving $G_{\text {unload }}$ $=60 \mathrm{ksi}$. In the first of the above equations, $\mathrm{F}_{\max }$ is the hydrostat loading pressure corresponding to $\mu_{\max }$ and $K$ is a function given by:

$$
K=\frac{B_{1}+B_{2}\left[\exp \left(b \mu_{\max }\right)-1\right]}{\mu_{\max }+1} \quad \mu_{\max }<\mu_{c}
$$

The constants, as determined from the given unload paths, are:

$$
\begin{aligned}
\mathrm{B}_{1} & =6.8946 \times 10^{-3} \mathrm{Mb} \\
\mathrm{B}_{2} & =6.9416 \times 10^{-7} \mathrm{Mb} \\
\mathrm{b} & =218.25
\end{aligned}
$$

For $\mu>\mu_{c}$, unloading is assumed to be reversible (i.e., it follows the load path).

Hydrostatic tension is limited by imposing a minimum value of pressure: $P_{\min }=-40 \mathrm{psi}$.

\section{A.1.5 Failure Surface}

A yield function $Y(P)$ was fit to the failure envelope supplied, where $Y=\sqrt{3 J_{2}^{\prime}}$ at failure. The functions derived are:

$$
\mathrm{Y}=3.4473 \times 10^{-6}+.48564 \mathrm{P}-2.7715 \times 10^{5} \mathrm{P}^{2} \quad \mathrm{P}<0
$$




$$
\begin{array}{r}
Y=1.241 \times 10^{-5}-1.737 \times 10^{6}\left(4.8263 \times 10^{-5}-\mathrm{P}\right)^{2.615} \\
0 \leq \mathrm{P}<4.8263 \times 10^{-5} \\
Y=1.241 \times 10^{-5} 4.8263 \times 10^{-5} \leq \mathrm{P} \leq 1.37 .89 \times 10^{-3} \\
Y=1.241 \times 10^{-5}+.01025\left(\mathrm{P}-1.3789 \times 10^{-3}\right) \\
P>1.3789 \times 10^{-3}
\end{array}
$$

Here the units for $Y$ and $P$ are $M b$. Plots of the failure surface are included in the following set of figures.

\section{A.1.6 Comparative Results}

Plots of stress vs strain, stress-difference vs pressure, and pressure vs volumetric strain for uniaxial strain load-unload paths computed with the model, along with the WES curves, are shown in Figure 3 in the text, and in Figures A-1 to A-3 in this appendix. Plots of the Hugoniot and hydrostat up to high pressures $(\sim 50 \mathrm{~kb})$ are shown in Figure A-4.

\section{A. 2 LAYER 2}

Due to the anticipated low stress environment, the pressures for Layer 2 were taken directly from the hydrostat, with no energy contribution.

\section{A.2.1 Loading Mode1}

The following equations were deduced for the loading hydrostat: 


$$
\begin{array}{lr}
P=a \mu & \mu \leq 0 \\
P=a \mu+\frac{b}{c-\mu}+\frac{b}{c} & 0<\mu \leq \mu_{c} \\
P=P_{c}+K_{\max }\left(\mu-\mu_{c}\right)=\left(K_{\max }-K_{c}\right) \mu *\left[1-\exp \frac{\mu_{c}-\mu}{\mu^{*}}\right] & \mu>\mu_{c}
\end{array}
$$

The values of the constants are:

$$
\begin{array}{rlrl}
\mathrm{a} & =5.7348 \times 10^{-3} \mathrm{Mb} & \mathrm{K}_{\mathrm{c}} & =.048263 \mathrm{Mb} \\
\mathrm{b} & =1.37095 \times 10^{-8} \mathrm{Mb} & \mathrm{K}_{\max } & =.689465 \mathrm{Mb} \\
\mathrm{c} & =6.75577 \times 10^{-3} \mathrm{Mb} & \mathrm{P}_{\mathrm{c}}= & 5.7604 \times 10^{-5} \mathrm{Mb} \\
\mu^{*}= & .25 & \rho_{\mathrm{o}}=2.0503 \mathrm{gm} / \mathrm{cm}^{3} \\
\mu_{c}=.006188 & & \left(1281 \mathrm{~b} / \mathrm{ft}^{3}\right)
\end{array}
$$

The shear modulus for loading was specified to be constant at a value of $20 \mathrm{ksi}$.

Initial values of the bulk modulus, the constrained modulus, Poisson's ratio, and the dilatational sound speed from the model are:

$$
\begin{array}{ll}
B_{0}=83.18 \mathrm{ksi} & \nu_{0}=.389 \\
M_{0}=109.8 \mathrm{ksi} & c_{0}=1,994 \mathrm{ft} / \mathrm{sec}
\end{array}
$$

\section{A. 2.2 Unloading Mode1}

In the hysteretic region, $\mu<\mu_{c}$, a model giving a fan of constant slope $\mathrm{P}-\mu$ unloading paths was used (slopes are a function of $\mu_{\max }$ ): 


$$
\begin{array}{ll}
\mathrm{P}=\mathrm{P}_{\max }+K\left(\mu-\mu_{\max }\right) & \mu_{\max }<\mu_{c} \\
\mathrm{P}=\mathrm{P}_{\mathrm{c}}+K_{\mathrm{c}}\left(\mu-\mu_{\mathrm{c}}\right) & \mu_{\max } \geq \mu_{\mathrm{c}}
\end{array}
$$

In this region the unloading bulk modulus varies from a minimum of $200 \mathrm{ksi}$ to a maximum of $700 \mathrm{ksi}$, equal to the bulk modulus for unloading at void closure. A constant value of $60 \mathrm{ksi}$ was used for the unloading shear modulus. $K$ is a function given by:

$$
K=K_{0}+K_{1} P_{\max } \quad \mu_{\max }<\mu_{c}
$$

where $P_{\max }$ is obtained from the loading hydrostat equations evaluated at $\mu_{\max }$. The constants, as determined from the given unload paths, are:

$$
\begin{aligned}
& \mathrm{K}_{0}=.013789 \mathrm{Mb} \\
& \mathrm{K}_{1}=.048263 \mathrm{Mb}
\end{aligned}
$$

For $\mu>\mu_{c}$, unloading is assumed to be reversible (it follows the load path).

Hydrostatic tension is limited by imposing a minimum value of pressure: $P_{\min }=-100 \mathrm{psi}$.

\section{A.2.3 Failure Surface}

A yield function $Y(P)$ was fit to the failure envelope suggested, where $Y=\sqrt{3 J_{2}^{\prime}}$ at failure. The functions derived are: 


$$
\begin{array}{rl}
Y= & 1.7237 \times 10^{-5}+2.2569 \mathrm{P}-3.5270 \times 10^{4} \mathrm{P}^{2} \\
& -6.8946 \times 10^{-6} \leq \mathrm{P} \leq 0 \\
Y=5.171 \times 10^{-5}-1.4996 \times 10^{9}\left(4.8263 \times 10^{-5}-\mathrm{P}\right)^{3.1597} & 0<\mathrm{P} \leq 4.8263 \times 10^{-5} \\
Y=5.171 \times 10^{-5} & 4.8263 \times 10^{-5}<\mathrm{P} \leq 2.4131 \times 10^{-3} \\
Y=5.171 \times 10^{-5}+.015385\left(\mathrm{P}-2.4131 \times 10^{-3}\right) \quad \mathrm{P}>2.4131 \times 10^{-3}
\end{array}
$$

Here the units for $Y$ and $P$ are $M b$.

\section{A.2.4 Comparative Results}

Plots of stress vs strain, stress-difference vs pressure, and pressure vs volumetric strain for uniaxial strain load-unload paths computed with the model, along with the WES curves, are shown in Figure 4 in the text, and in Figures A-5 and A-6 in this appendix.

\section{A. 3 STEEL}

An existing equation of state for iron was employed.* Appropriate mechanical and strength properties for the steel alloy of the penetrator were then added to the model.

*M. H. Wagner, Analytical Studies of Projectile Design and Performance, Shock Hydrodynamics Report 7584-06, August 1971. 
The following properties were assumed:

$\begin{array}{lcl}\text { Normal density, } \rho_{\mathrm{O}}: & 7.84 \mathrm{gm} / \mathrm{cm}^{3} & \left(489 \mathrm{lb} / \mathrm{ft}^{3}\right) \\ \text { Bulk modulus, } \mathrm{K}_{\mathrm{O}}: & 1.686 \mathrm{Mb} & \left(2.445 \times 10^{7} \mathrm{psi}\right) \\ \text { Shear modulus, } \mathrm{G}: & .83 \mathrm{Mb} & \left(1.204 \times 10^{7} \mathrm{psi}\right) \\ \text { Yield strength, } \mathrm{Y}: & .0034473 \mathrm{Mb} & (50,000 \mathrm{psi})\end{array}$

The shear modulus was assumed to be constant. The bulk modulus varies through the equation of state. A conventional von Mises yield model was employed; i.e., states are elastic for $\sqrt{3 J_{2}^{\prime}}<Y=$ constant. Hydrostatic tension was limited by imposing a minimum value of pressure:

$$
P_{\text {min }}=-\frac{1}{3} Y
$$

With this condition, the tensile stress is limited to a value $=Y$.

The low-pressure (sub-transition) portion of the previously-formulated equation of state of iron covers the range of interest and is given by:

$$
\begin{aligned}
& P=a_{1} \mu\left(1-\frac{\gamma}{2} \mu\right)+\gamma \rho e \\
& P=\left(a_{1} \mu+a_{2} \mu^{2}+a_{3} \mu^{3}\right)\left(1-\frac{\gamma}{2} \mu\right)+\gamma \rho e
\end{aligned}
$$

The values of the constants are:

$$
\begin{array}{llrl}
\mathrm{a}_{1}=1.686 \mathrm{Mb} & \gamma=1.81 \\
\mathrm{a}_{2}=7.1889 \mathrm{Mb} & \mu_{1}=.06717 \\
\mathrm{a}_{3}=-70.354 \mathrm{Mb} &
\end{array}
$$




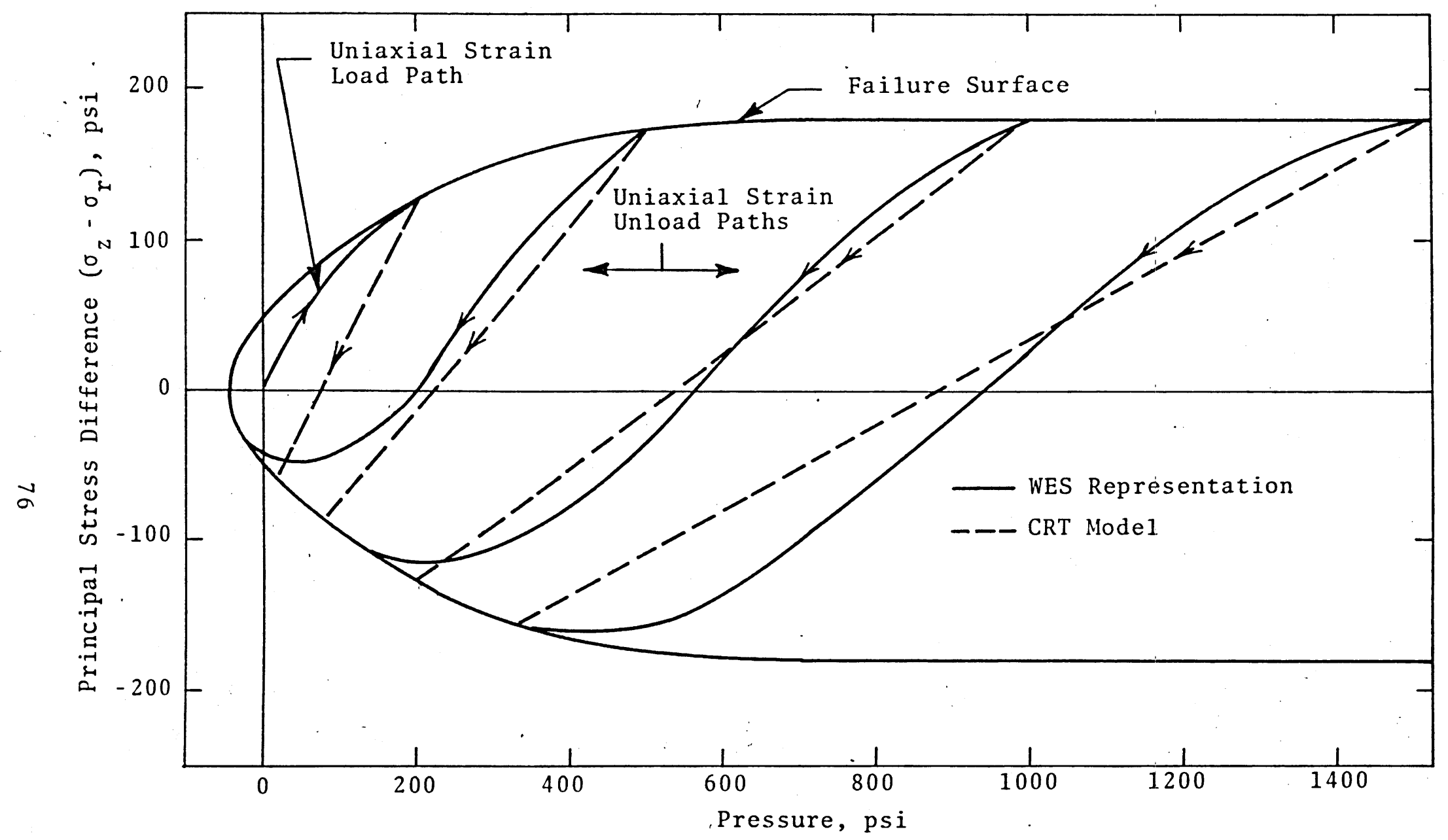

Figure A-1. Uniaxial Strain Stress Paths and Failure Surface for Layer 1 


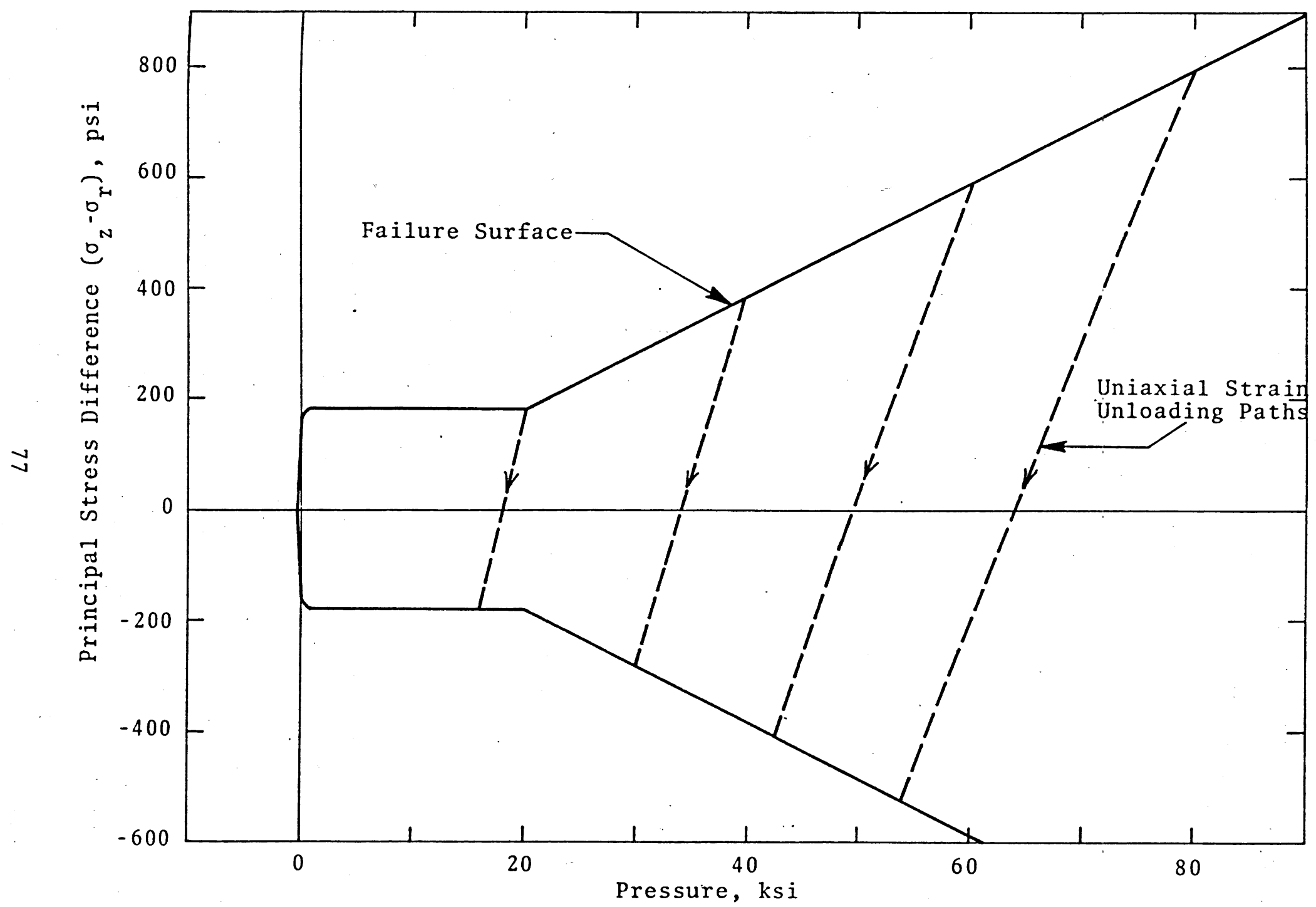

Figure A-2. Uniaxial Strain Unloading Paths and Failure Surface in High-Pressure Region for Layer 1 


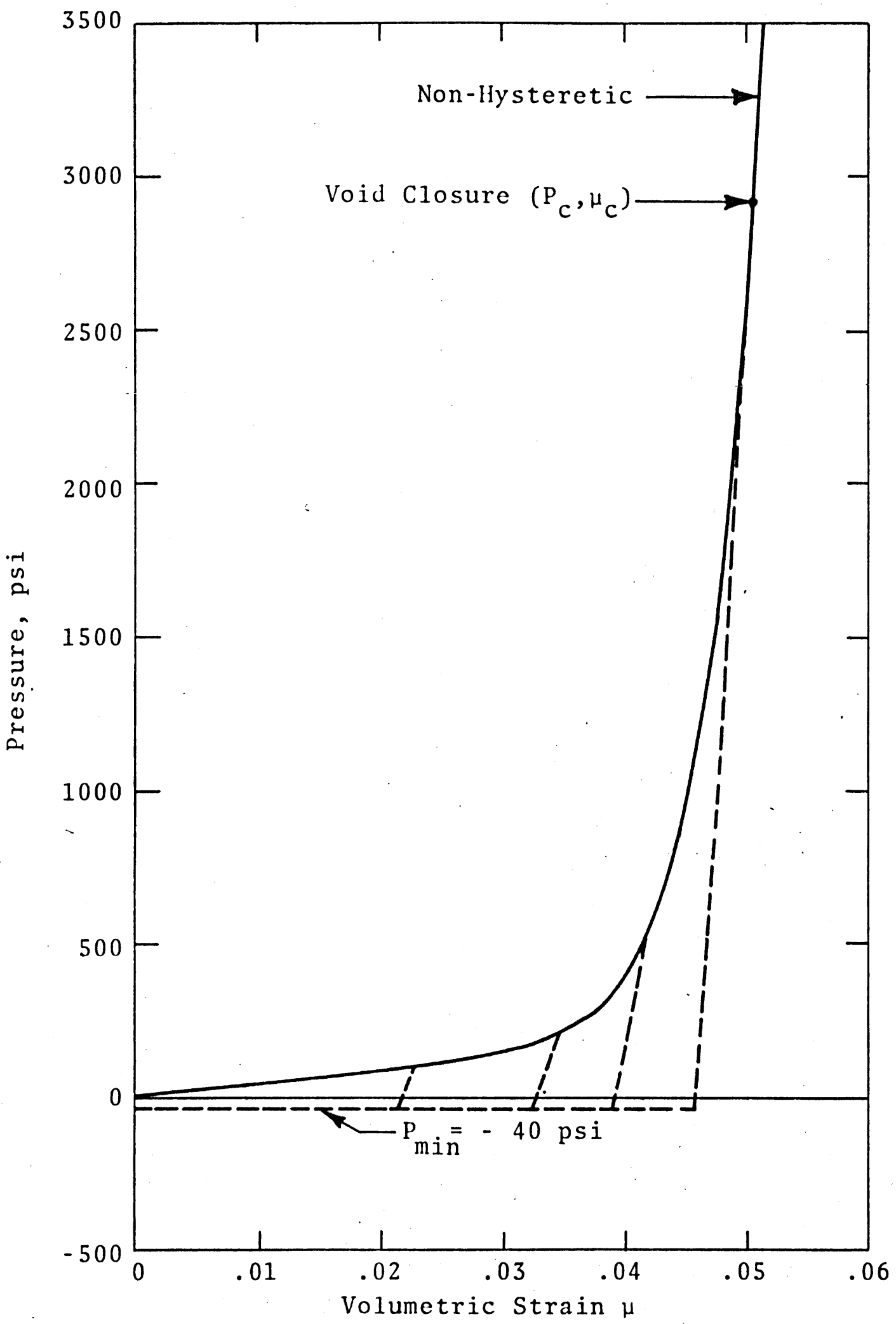

Figure A-3. Hydrostatic Load-Unload Curves for Layer 1 


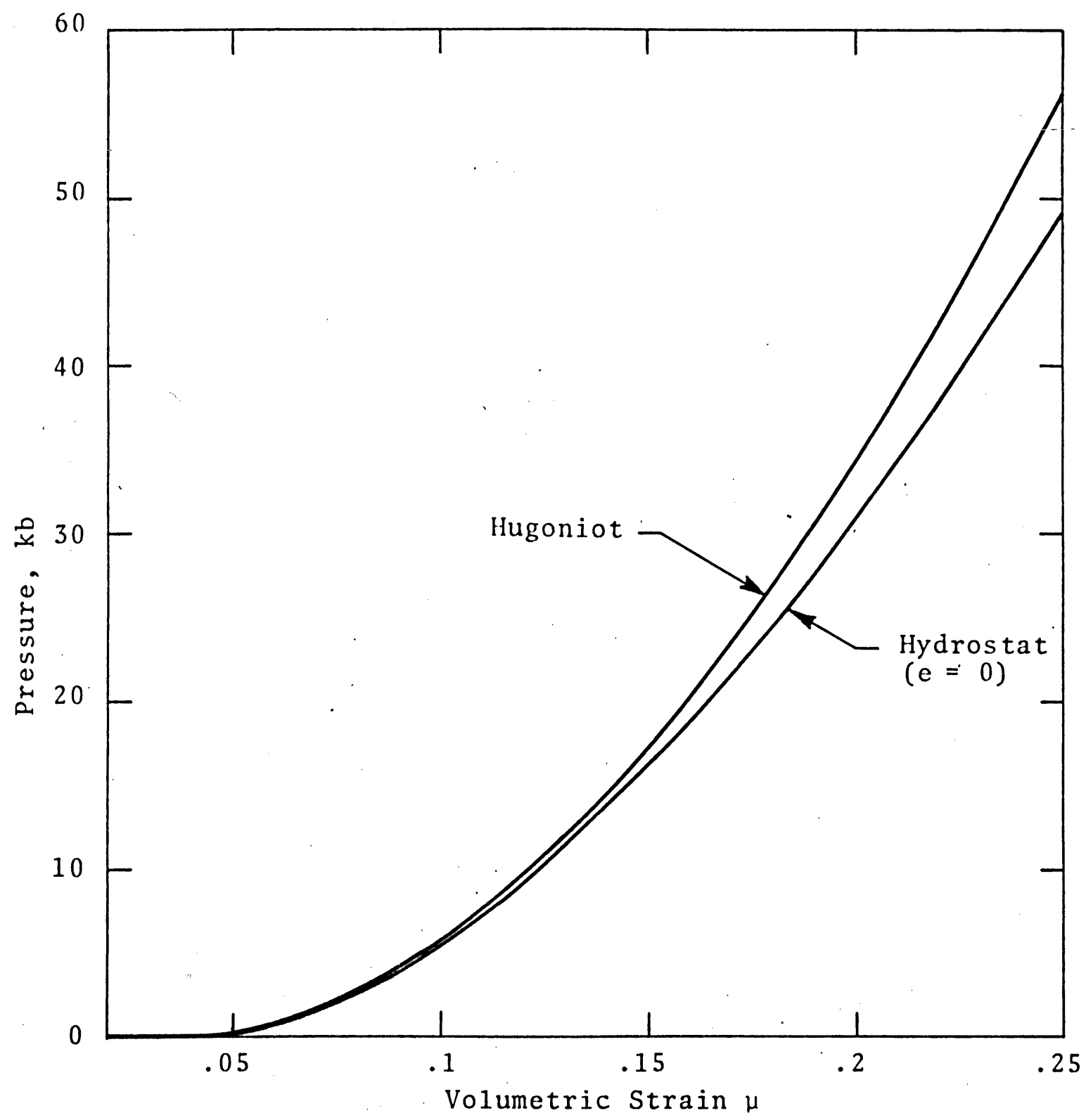

Figure A-4. Hugoniot and Loading Hydrostat for Layer 1 


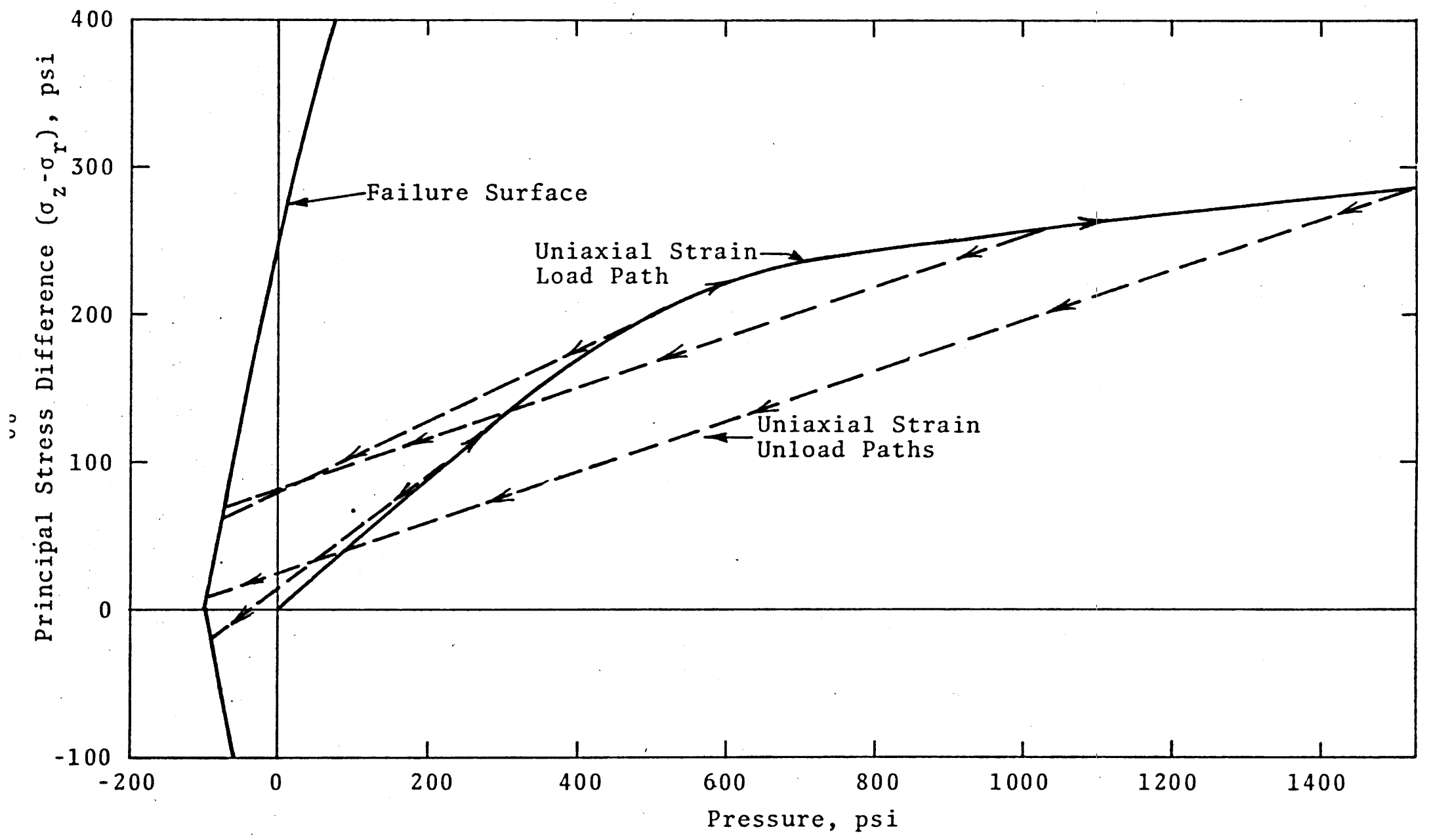

Figure A-5. Uniaxial Strain Stress Paths for Layer 2 


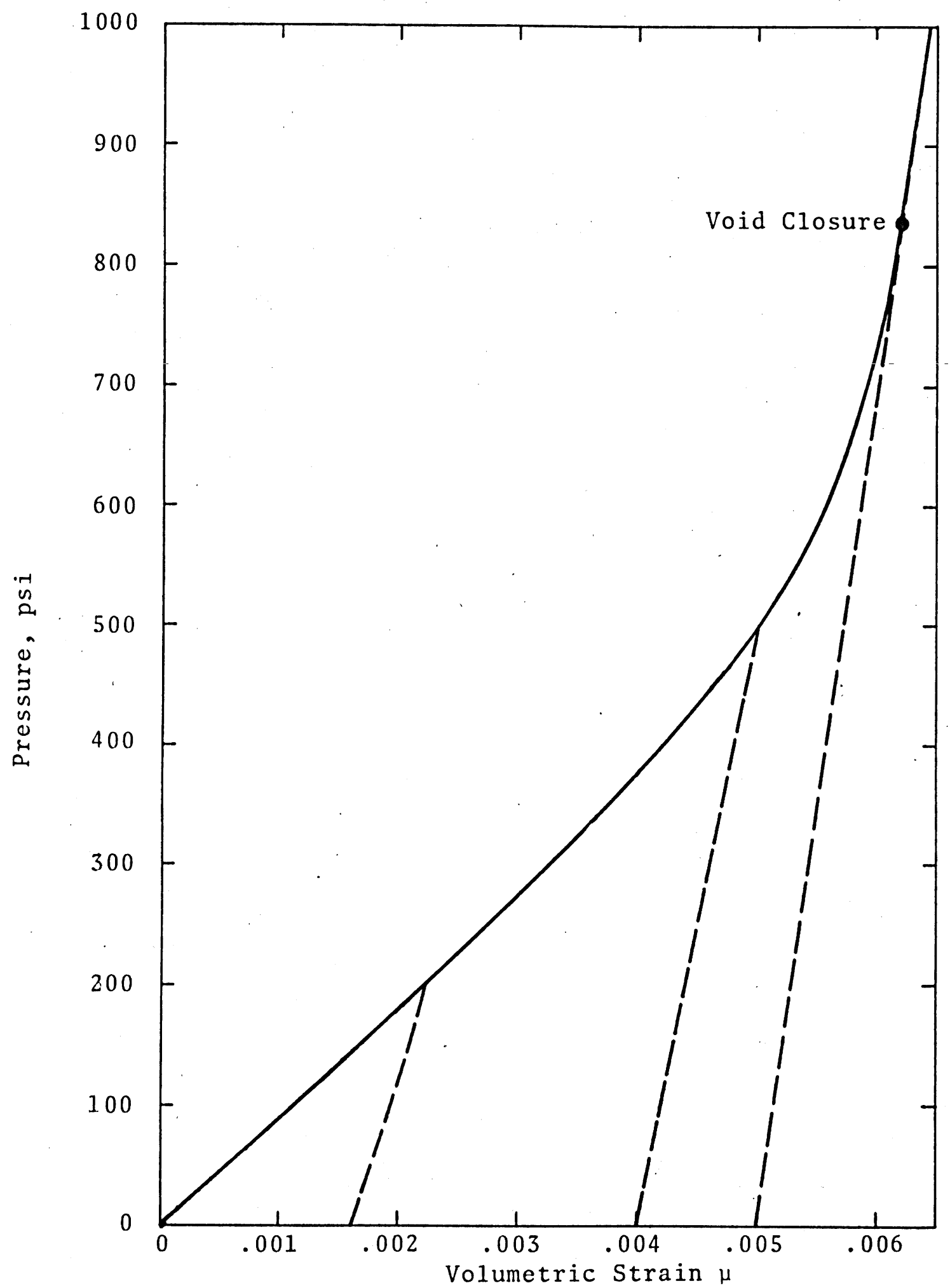

Figure A-6. Hydrostatic Load-Unload Curves for Layer 2 


\section{APPENDIX B}

\section{DISTORTION, VELOCITY, AND PRINCIPAL STRESS}

FIELD PLOTS - DEFORMABLE-BODY SOLUTION

A series of field plots of the computational grid, particle velocities, and principal stresses which illustrate the projectile and soil response during the deformablebody solution were prepared. These are shown for the following penetration depths and times.

\begin{tabular}{|c|c|c|c|c|}
\hline $\begin{array}{l}\text { Depth } \\
\text { (in.) }\end{array}$ & $\begin{array}{c}\text { Time } \\
\text { ( } \mu \text { sec) }\end{array}$ & $\begin{array}{l}\text { Figure No. } \\
\text { Distortion } \\
\text { (Grid) }\end{array}$ & $\begin{array}{l}\text { of Plot f } \\
\text { Velocity }\end{array}$ & Stress \\
\hline .56 & 23.3 & B - 1 & B - 2 & $B-3$ \\
\hline 1.86 & 77.4 & B -4 & & \\
\hline 3.07 & 128.1 & B -5 & & \\
\hline & & B-6 (Rezone) & & · \\
\hline 5.04 & 210.1 & & & B - 7 \\
\hline 6.33 & 263.9 & B - 8 & B - 9 & $B-10$ \\
\hline & & B-11 (Rezone) & & \\
\hline 9.84 & 411.0 & $B-12$ & $B-13$ & $B-14$ \\
\hline 15.29 & 638.8 & $B-15$ & $B-16$ & \\
\hline 18.06 & 754.7 & $\mathrm{~B}-17$ & & \\
\hline 20.03 & 837.4 & $B-18$ & B - 19 & B -20 \\
\hline
\end{tabular}

The velocity vector field plots show the direction and magnitude of the particle velocity at each lattice point in the computing grid.

In the stress field plots, the principal components of the stress tensor for each cell use these conventions: 
The magnitude of the two principal stresses in the $r-z$ plane are plotted in their corresponding principal directions. The third principal stress (in the azimuthal direction) is plotted along the line bisecting the other two principal directions. Vectors pointing to the right are compressive, to the left, tensile. An example of how a stress tensor is plotted is sketched below:

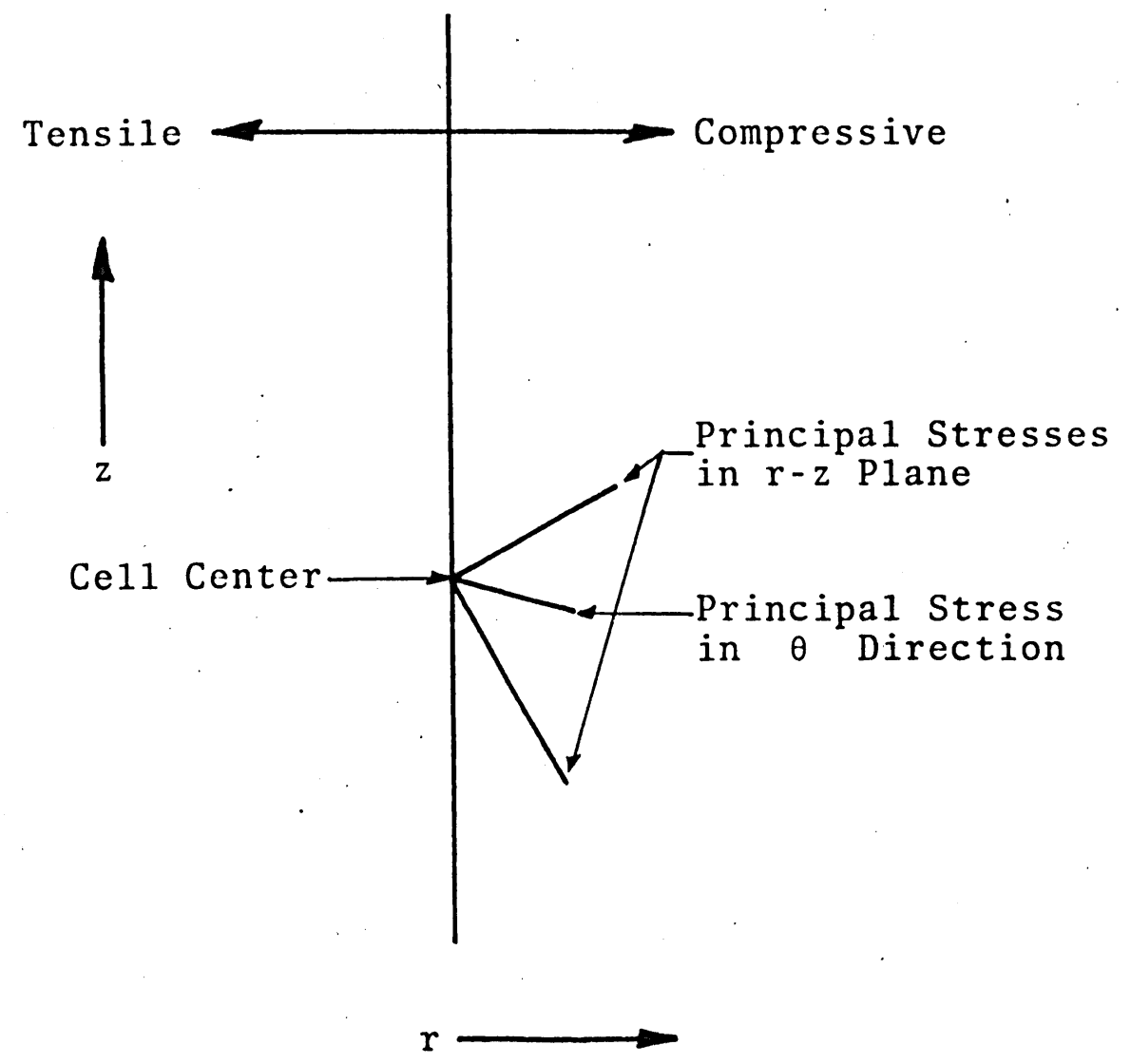


The first three figures of the grid (B-1, B-4, and $B-5)$ show the initial entry of the penetrator into the top surface of the soil. A local rezone is required, as shown in Figure B-6, when the surface grid point contacts the penetrator surface (see Figure B-5).

In Figure B-7, the stress loading of the projectile nose after 5 " penetration is seen. Note the strong vertical orientation of the stress vectors, due to the free surface at the periphery.

Figure B-11 shows another rezone which was performed to re-orient the grid. A small portion of the distended soil that was flying off was also removed at this time.

Figures $B-10$ and $B-14$ show a buildup of radial and hoop tension along the lower end of the slug and a high vertical compressive stress in the thin section connecting the nose and the slug.

- The detachment of the soil from the penetrator and hole formation may be seen in Figures B-17 and B-18. 


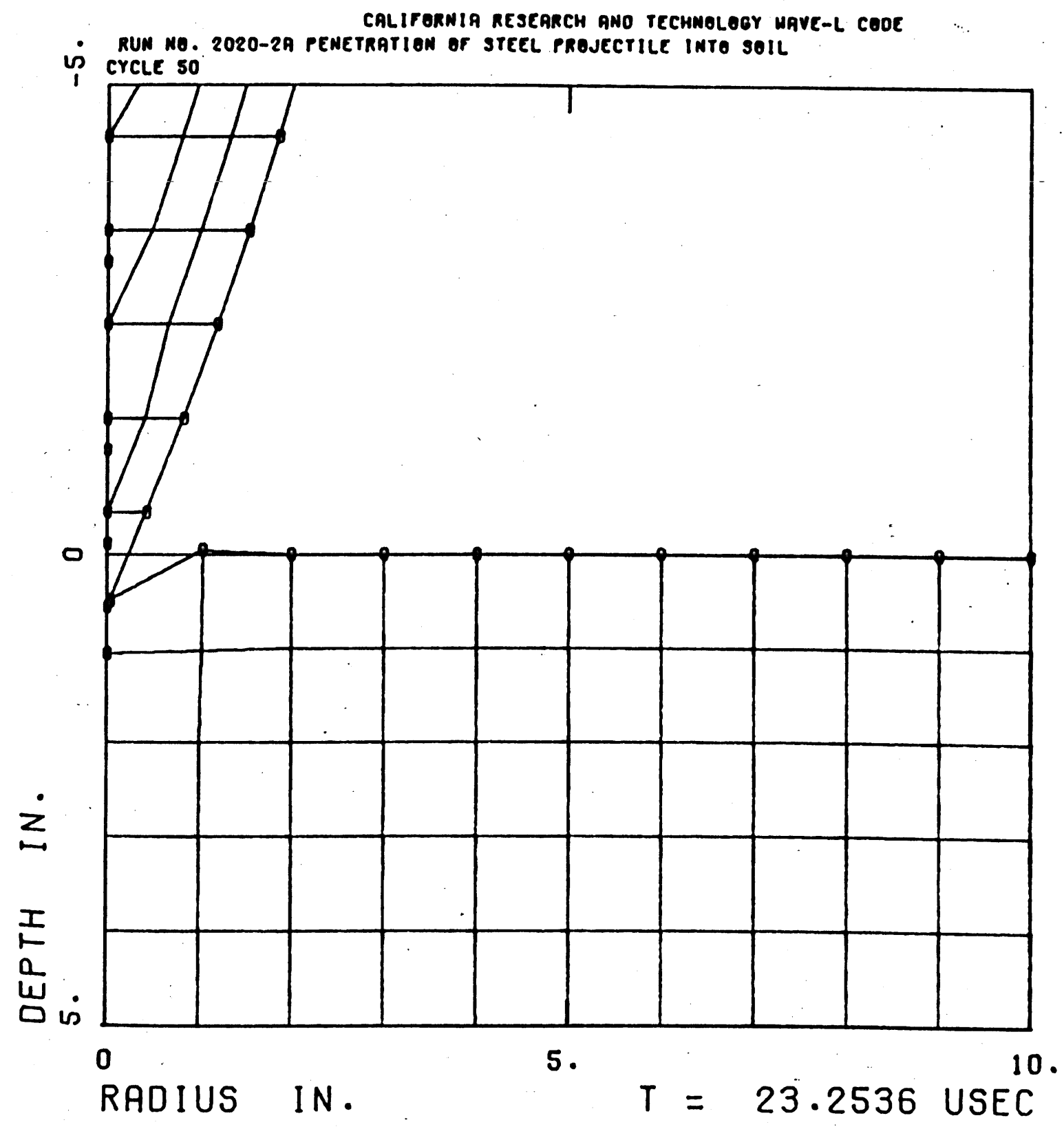

Figure B-1. Grid Configuration with Projectile at .56 in. Depth 


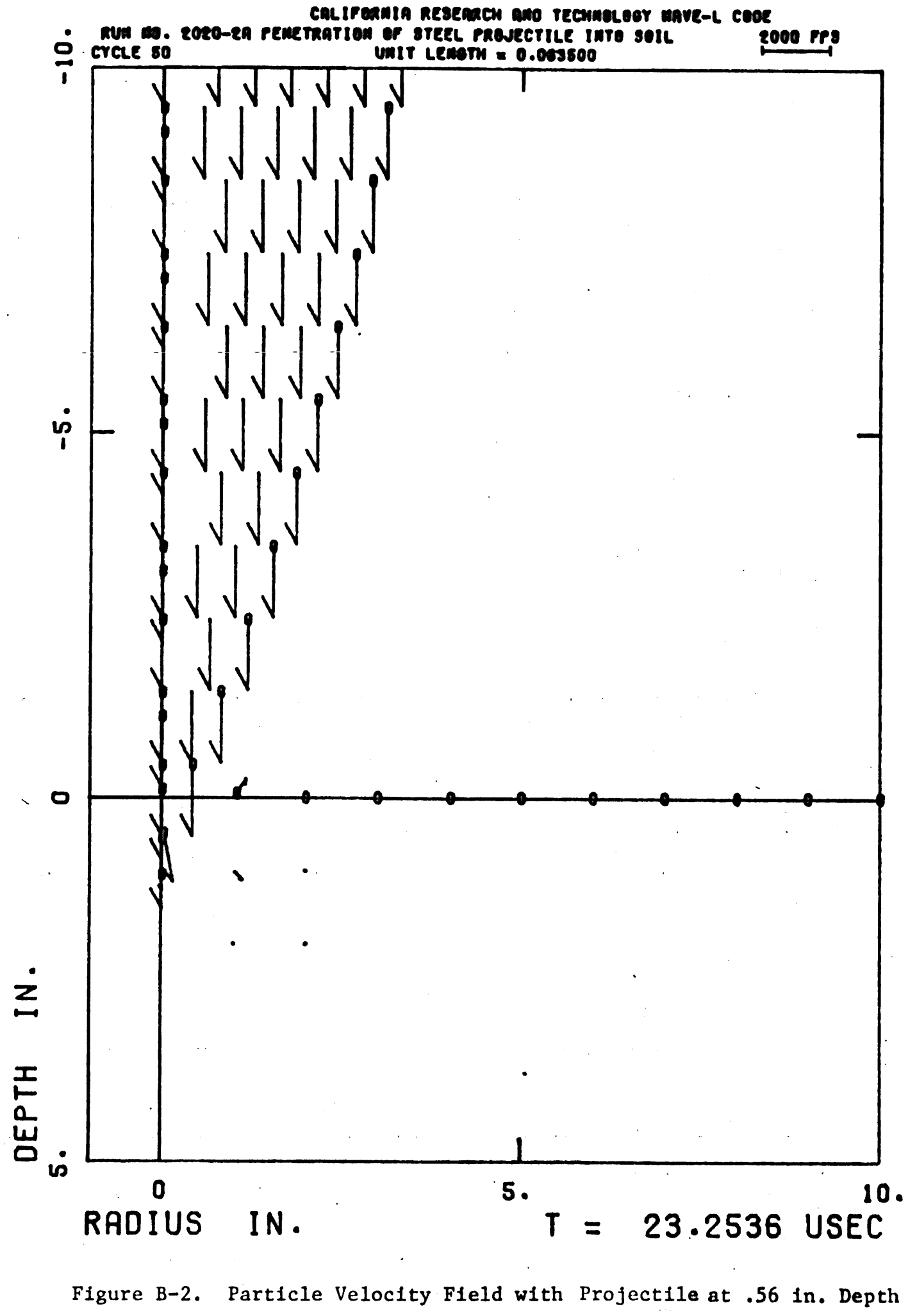




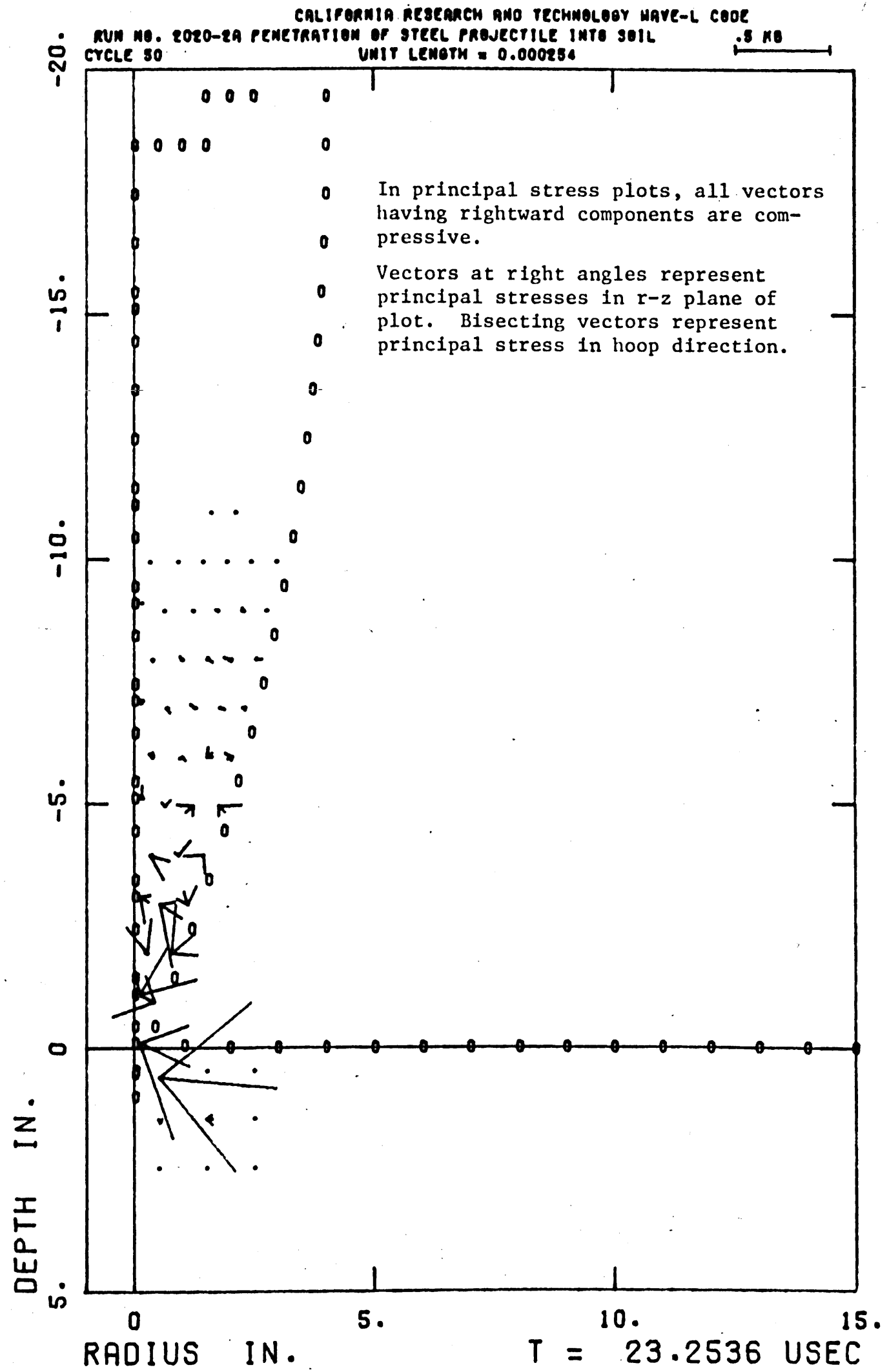

Figure B-3. Principal Stress Field with Projectile at .56 in. Depth 
CALIFORWIA REOEARCH ANO TECHHOLOOY MAVE-L COOE

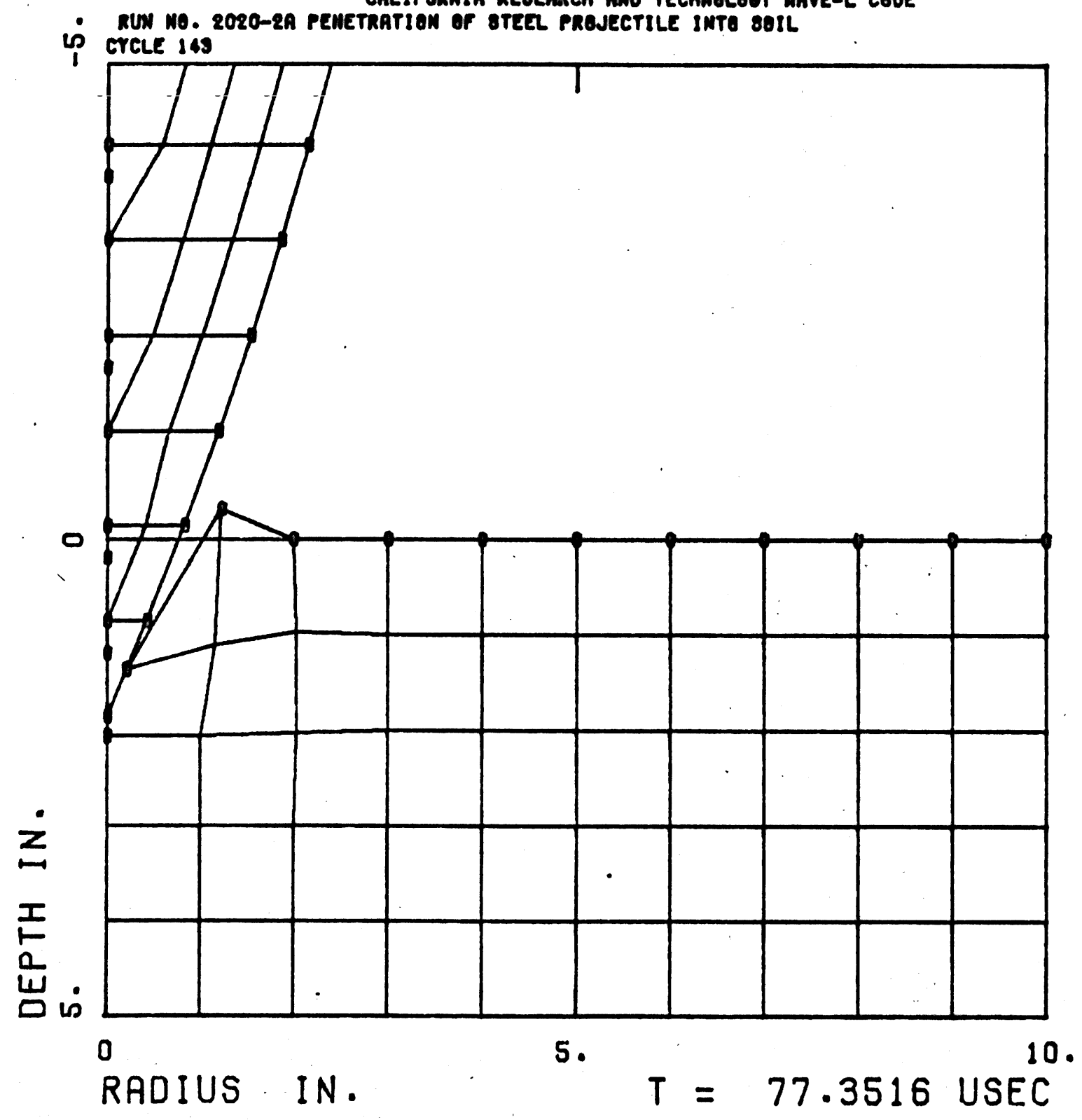

Figure B-4. Grid Configuration with Projectile at 1.86 in. Depth 


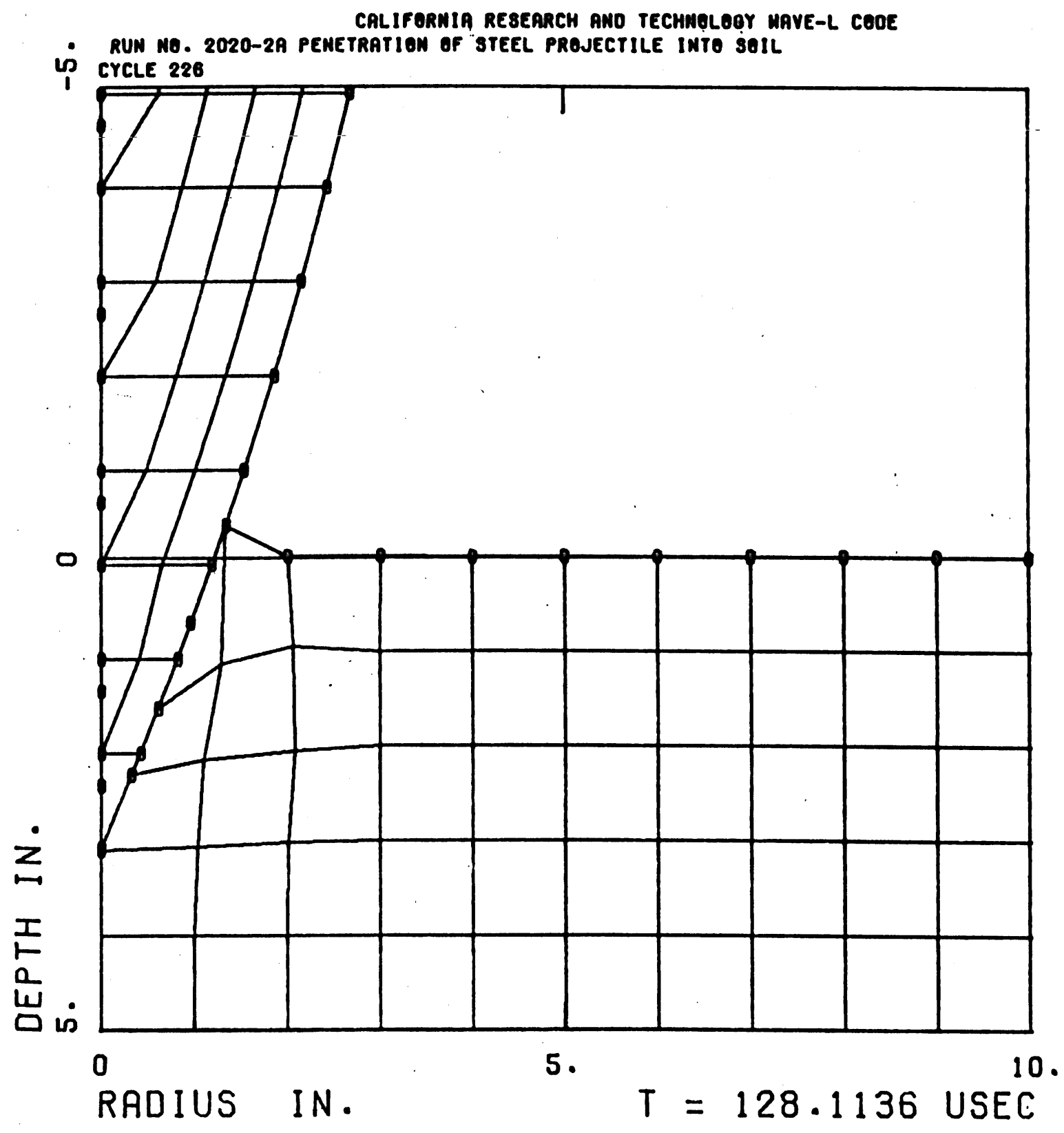

Figure B-5. Grid Configuration with Profectile at 3.07 in. Depth 


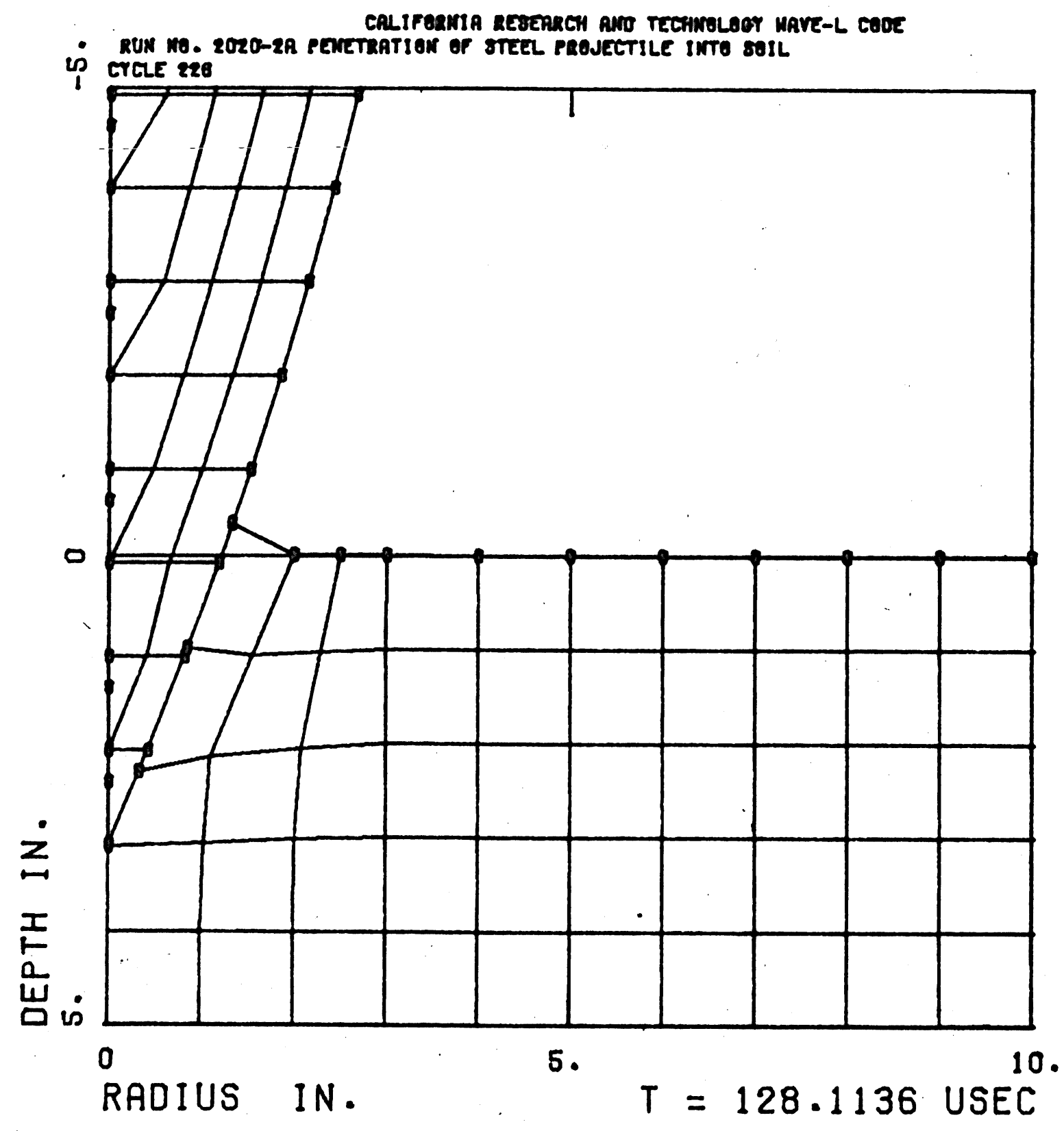

Figure B-6. Grid Configuration Following Rezone 


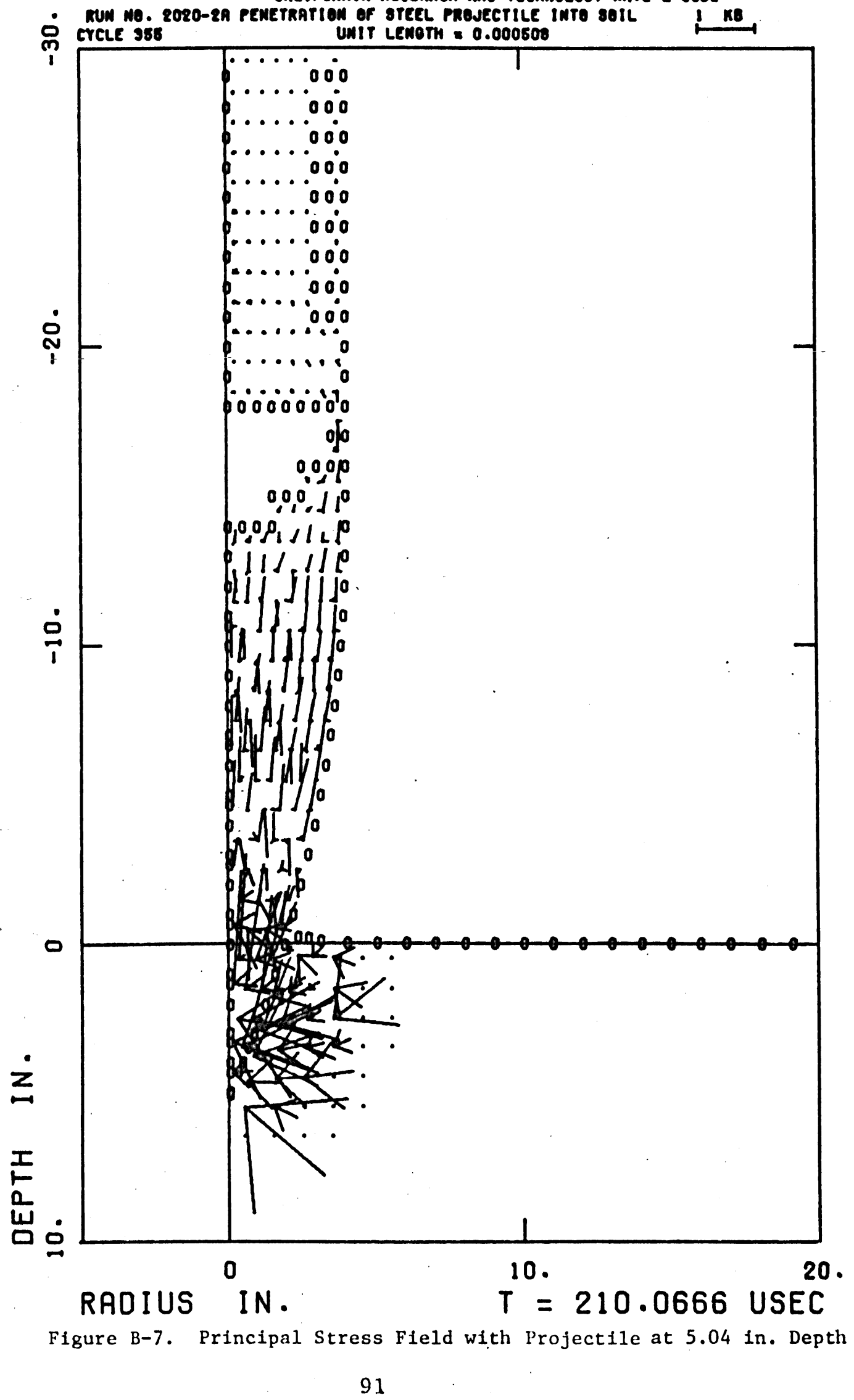




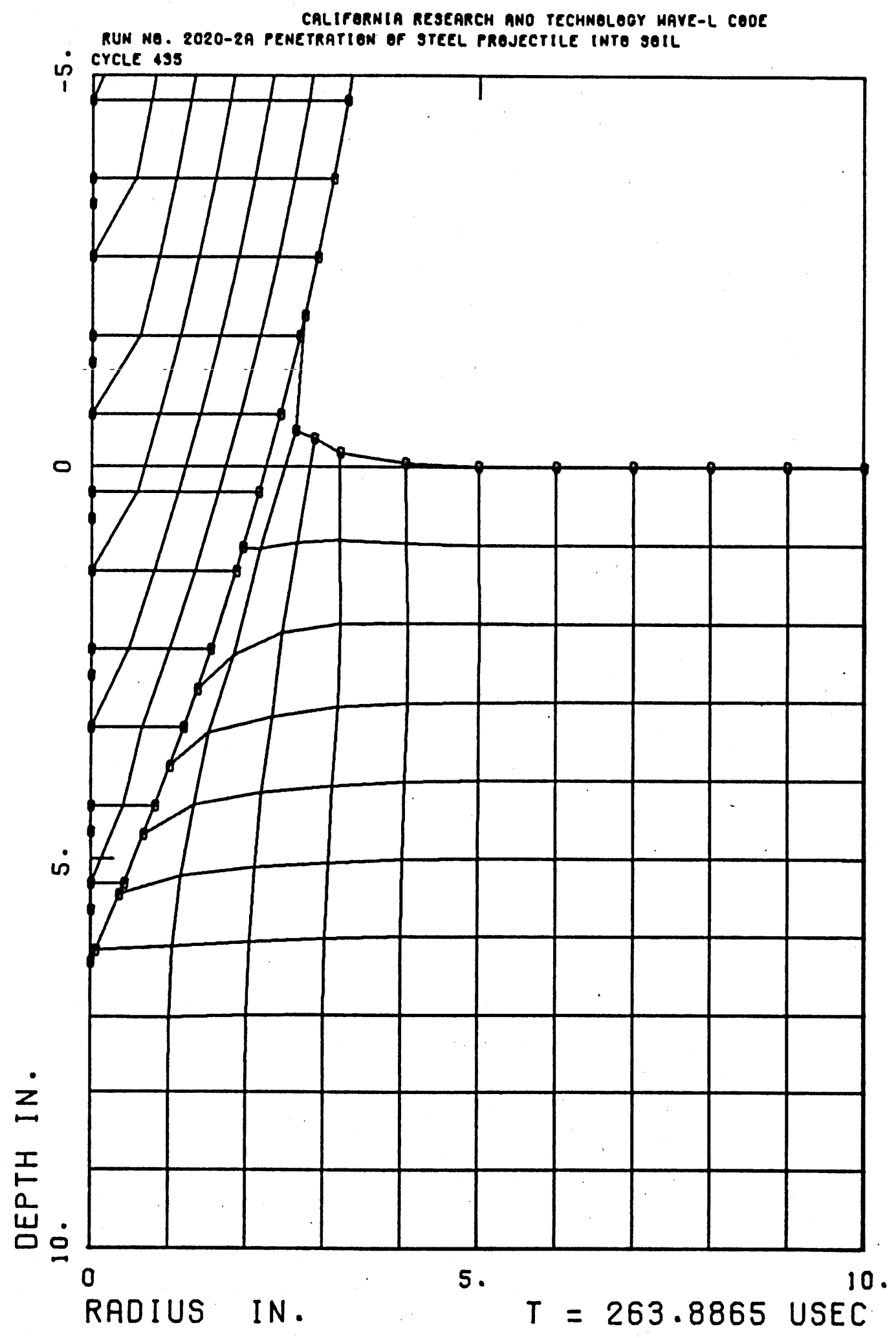

Figure B-8. Grid Configuration with Projectile at 6.33 in. Depth 


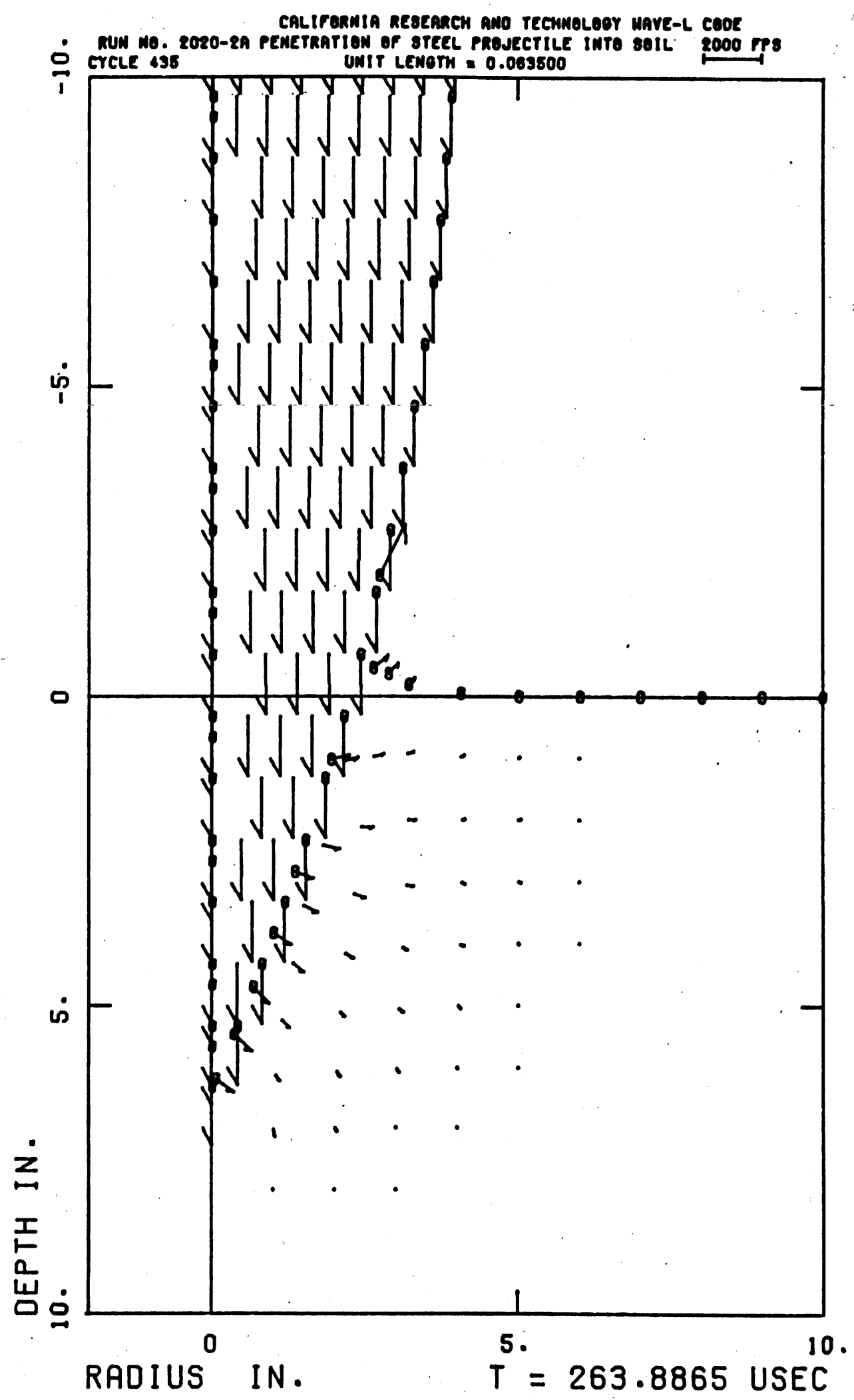

Figure B-9. Particle Velocity Field with Projectile at 6.33 in. Depth 


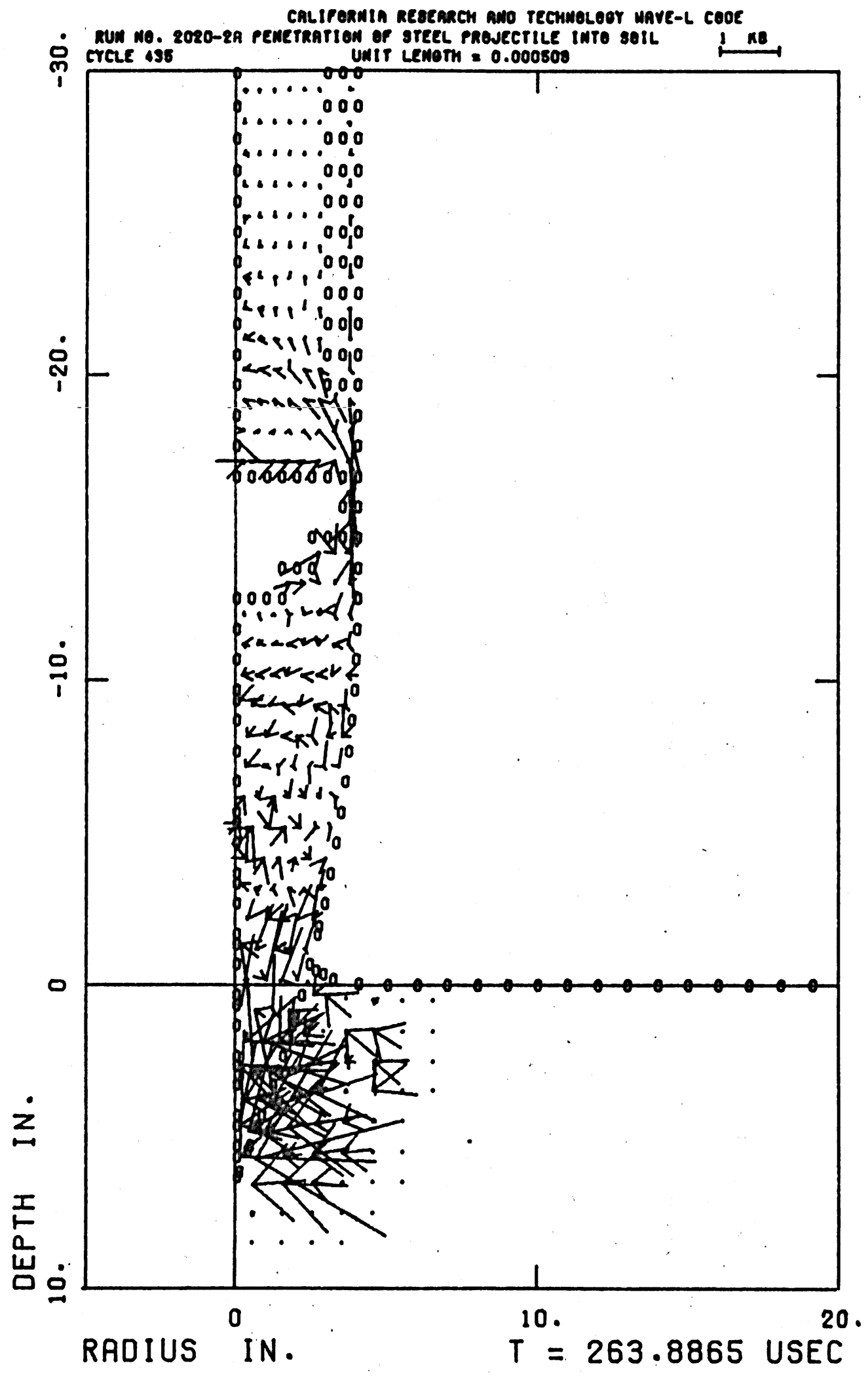

Figure B-10. Principal Stress Field with Projectile at 6.33 in. Depth 


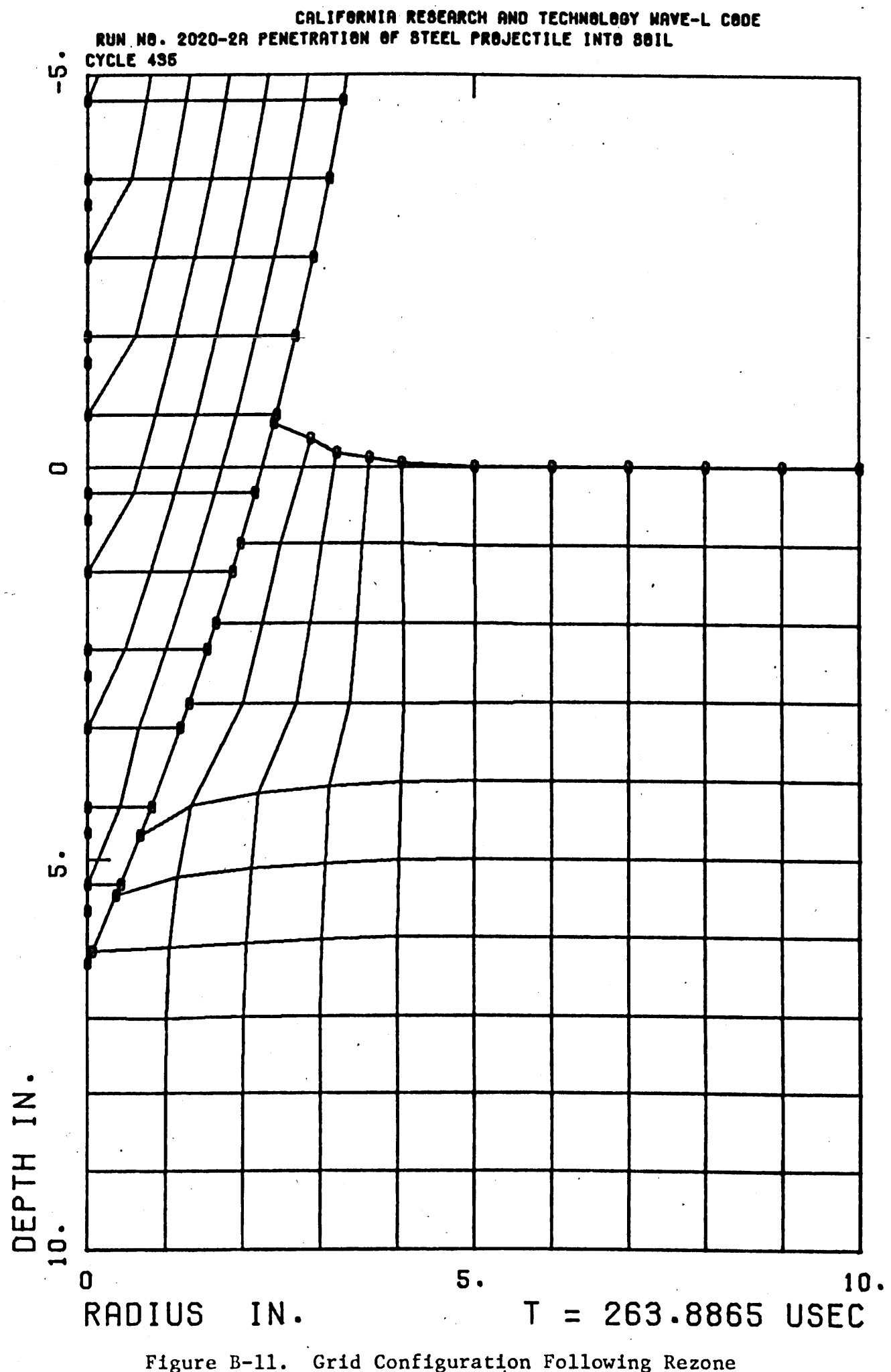




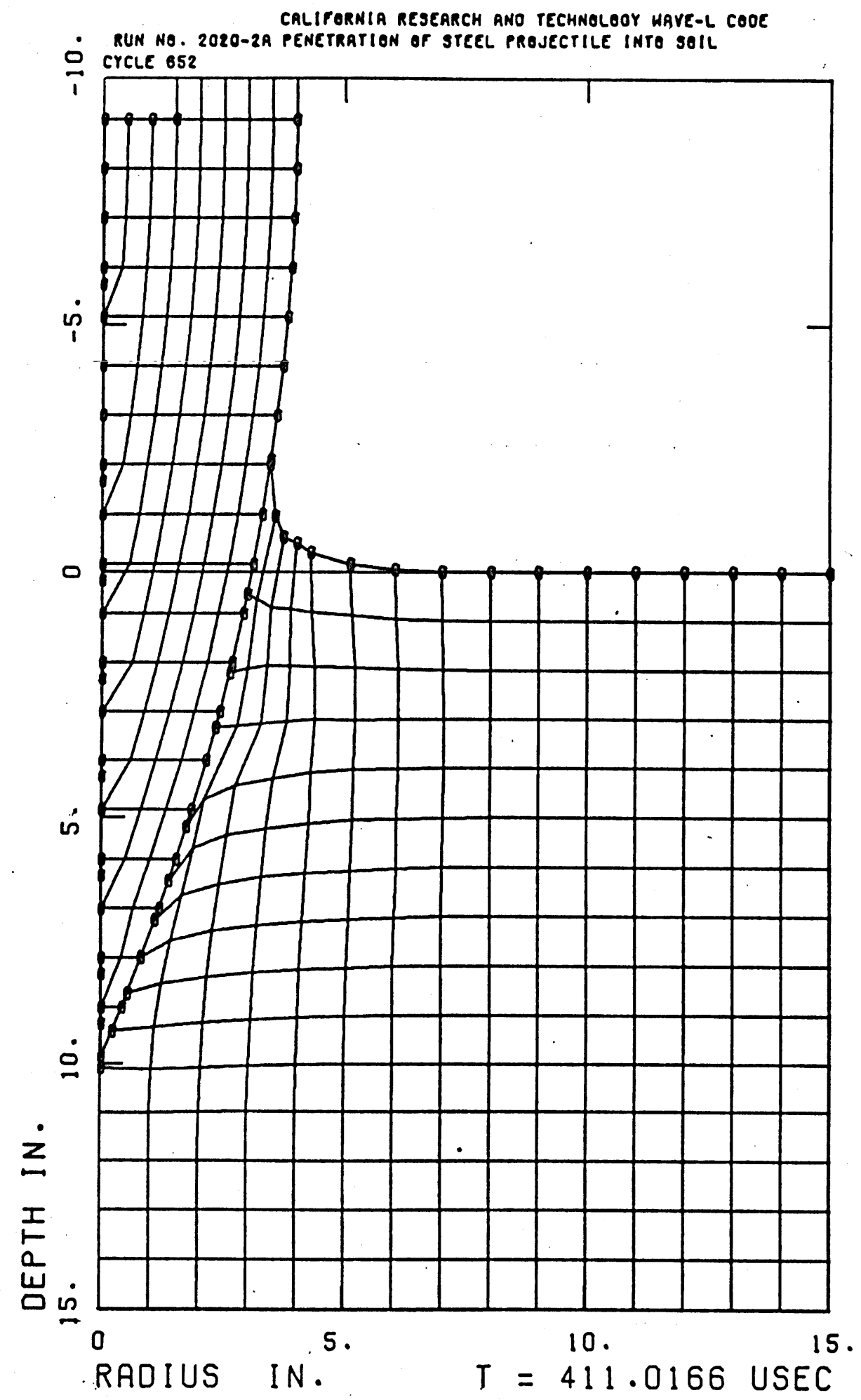

Figure B-12. Grid Configuration with Projectile at $9.84 \mathrm{In}$. Depth 


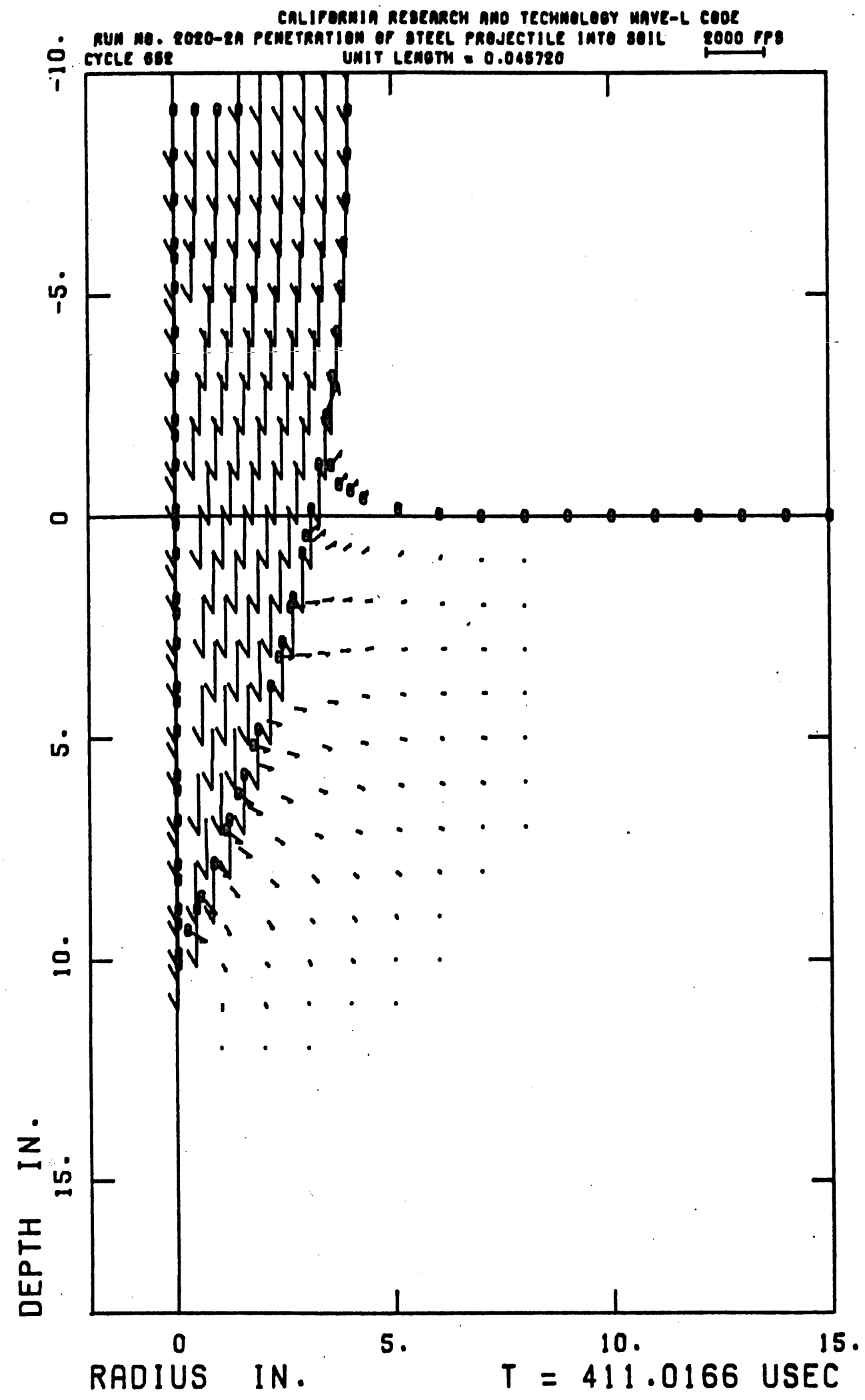

Figure B-13. Particle Velocity Field.with Projectile at 9.84 in. Depth 


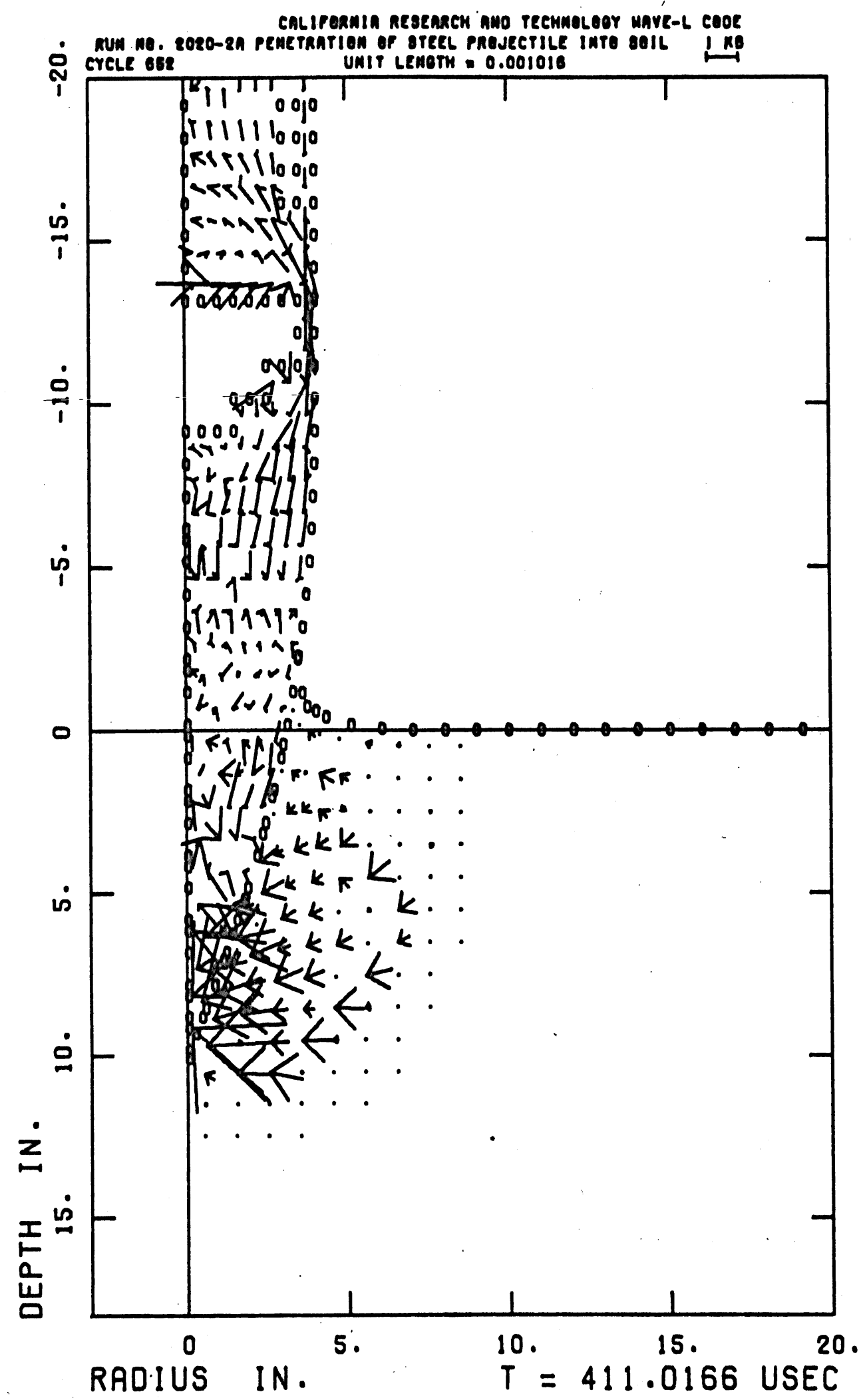

Figure B-14. Principal Stress Field with 'Projectile at 9.84 in. Depth 


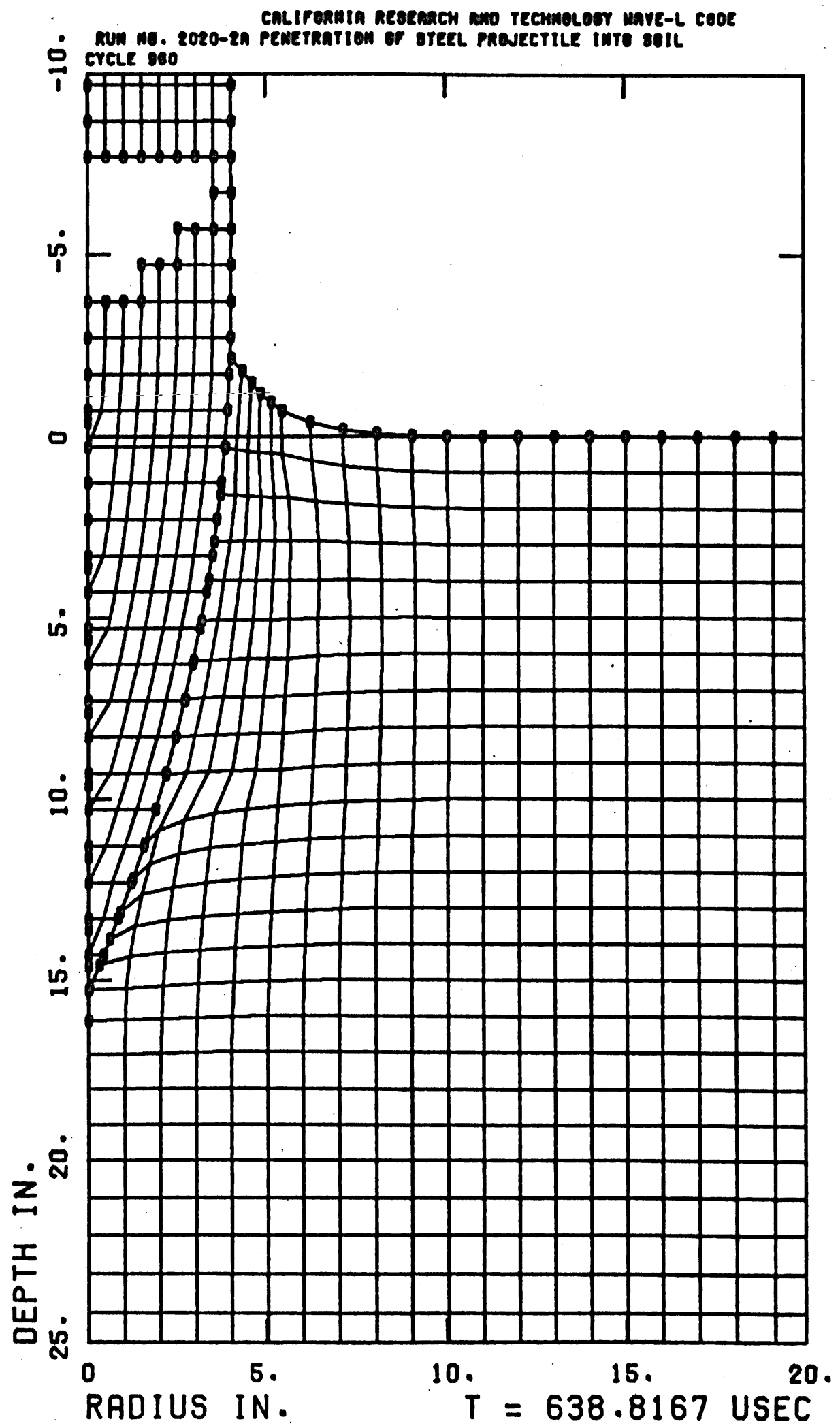

Figure B-15. Grid Configuration with Projectile at 15.29 in. Depth

99 


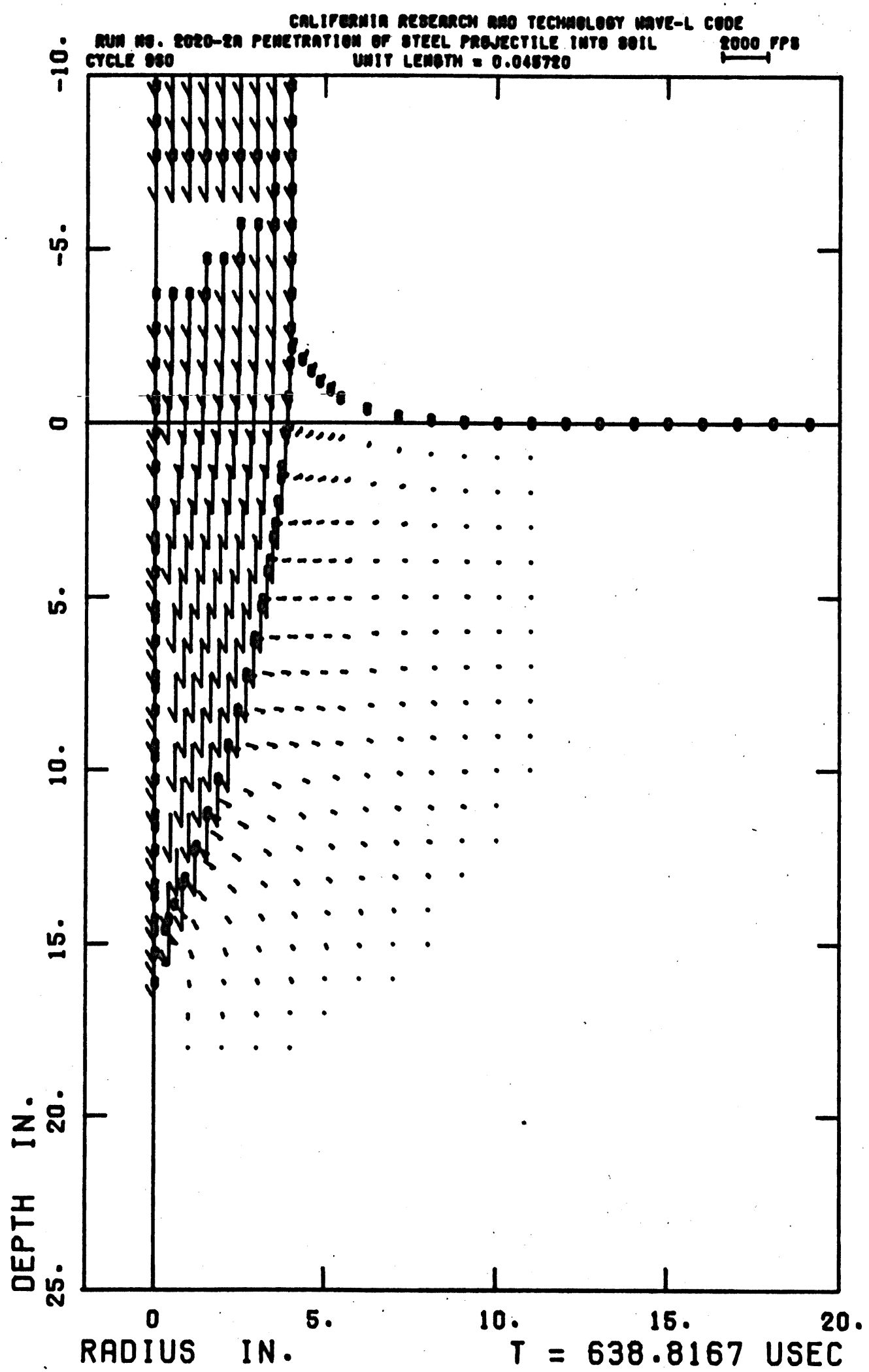

Figure B-16. Particle Velocity Field with Projectile at 15.29 in. Depth 


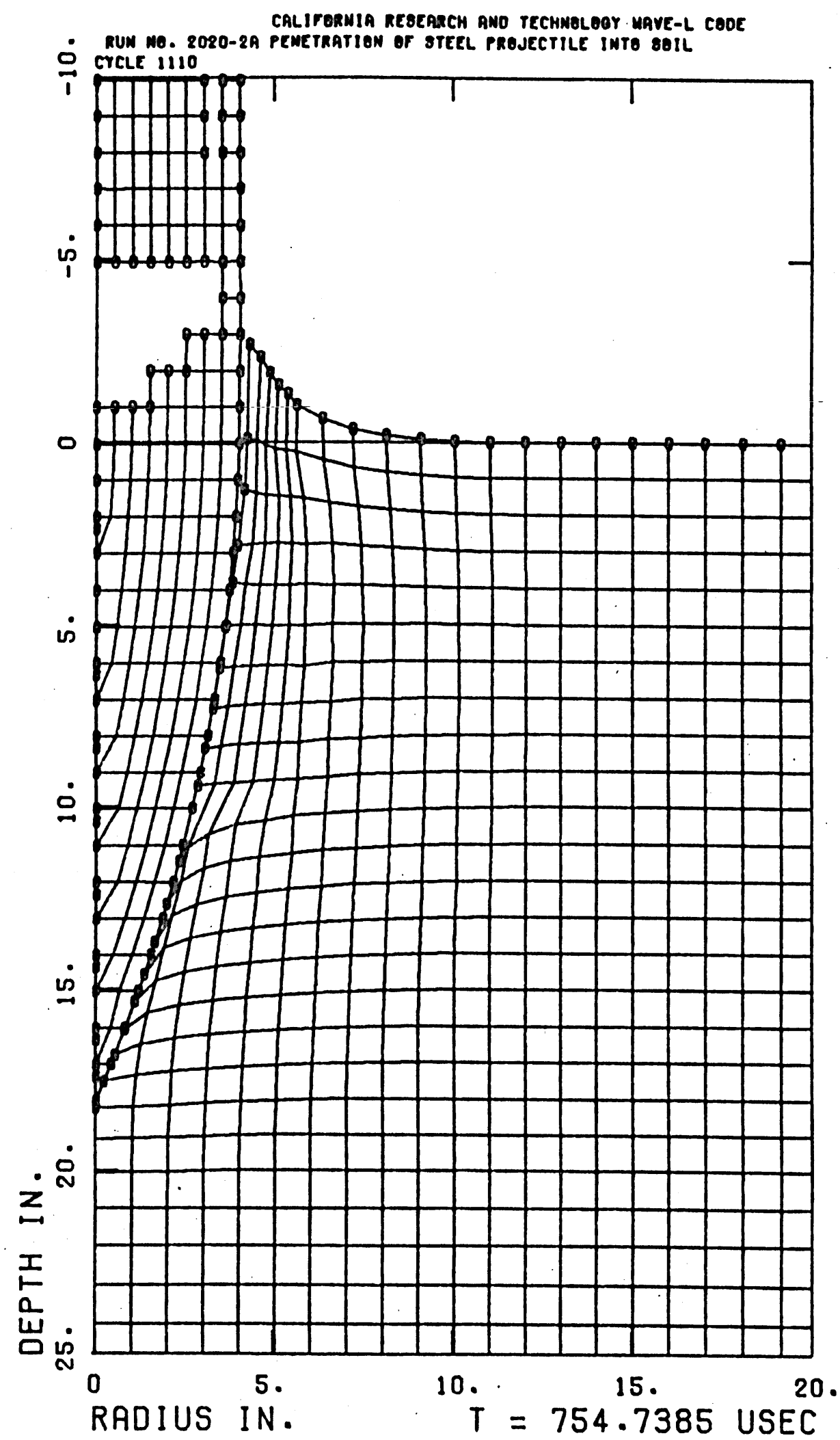

Figure B-17. Grid Configuration with Projectile at 18.06 in. Depth 101 


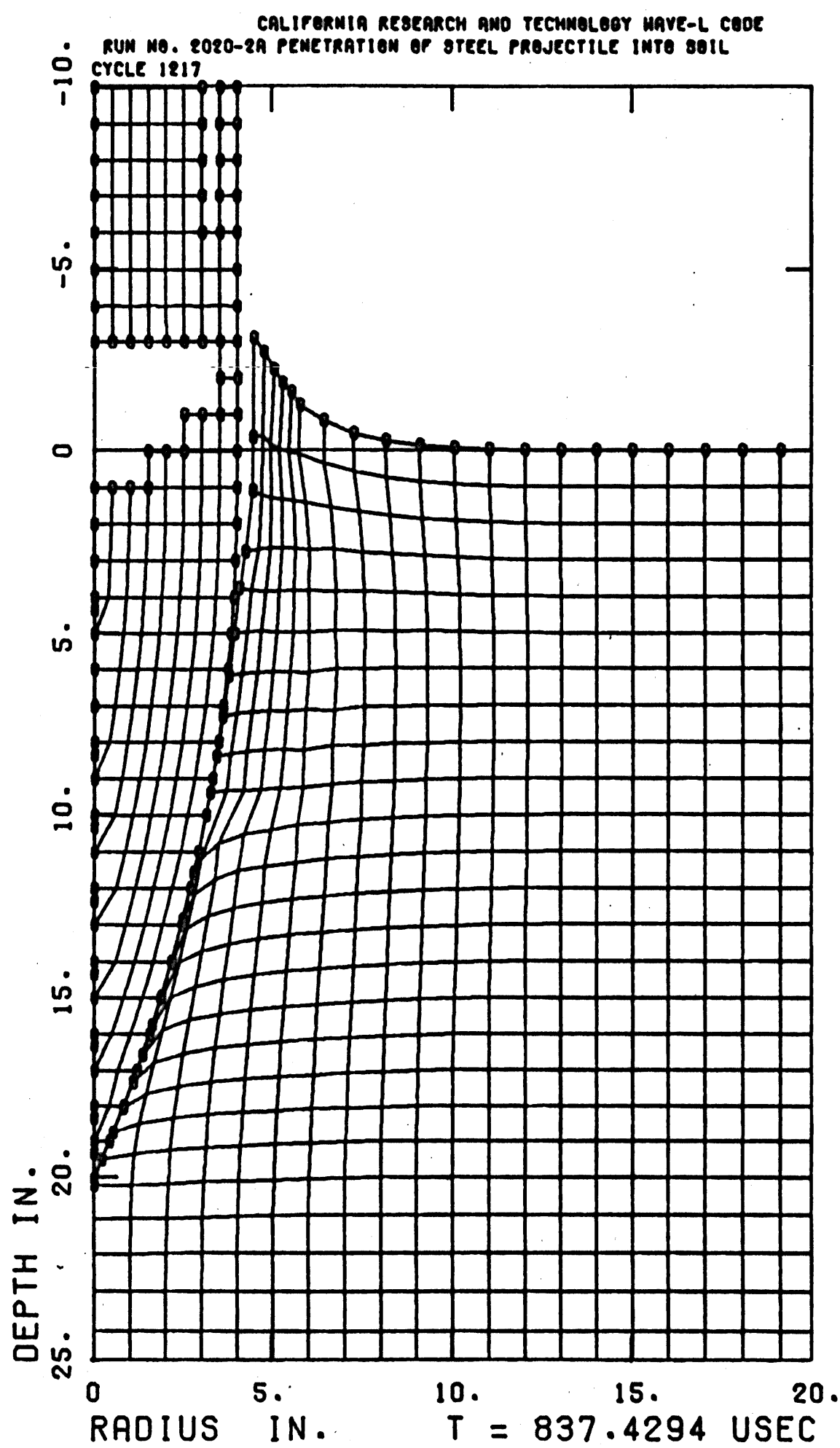

Figure B-18. Grid Configuration at End of Deformable-Body Solution, Projectile at 20.03 In. Depth

102 


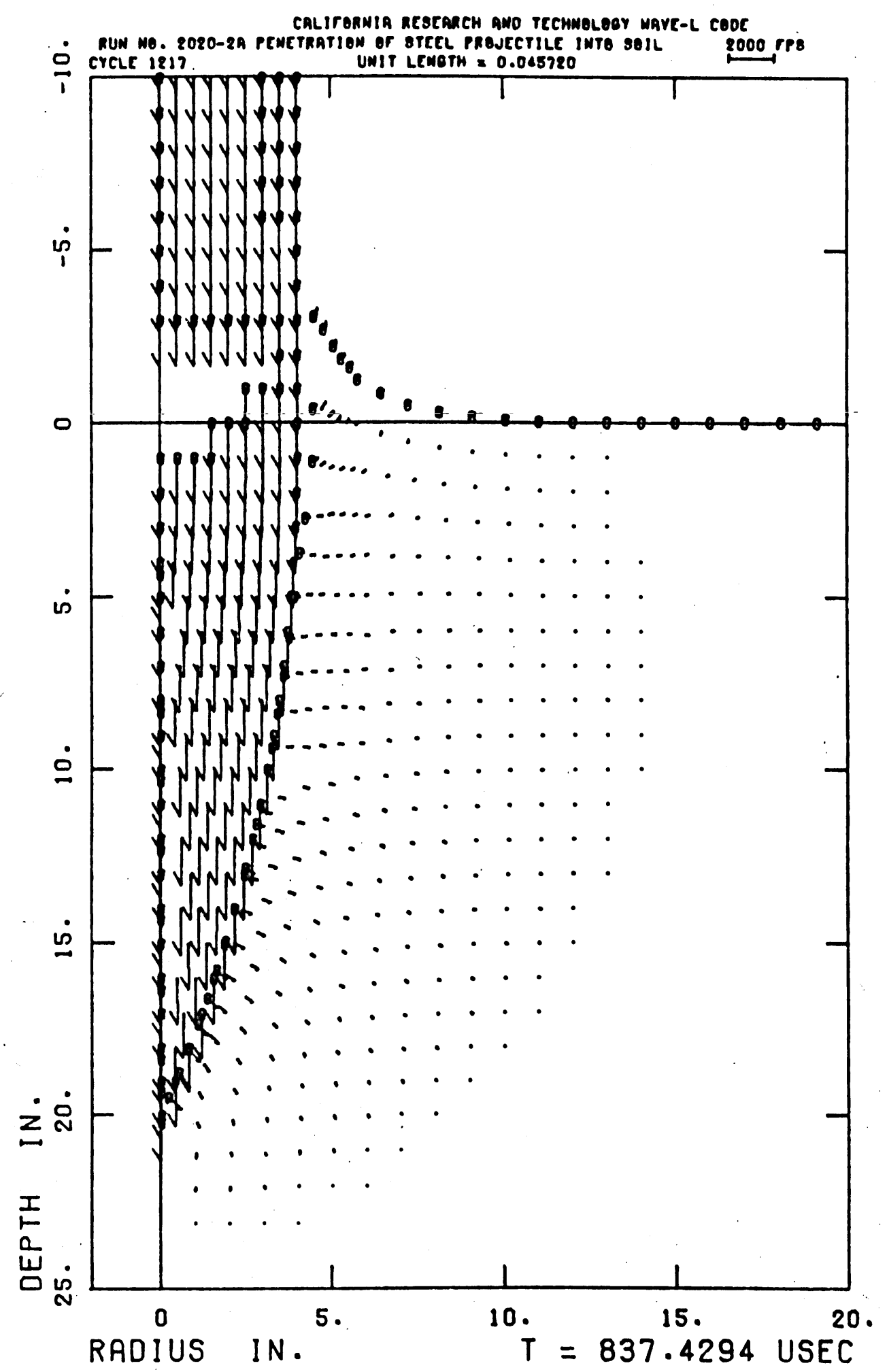

Figure B-19. Particle Velocity Field at . End of Deformable-Body
Solution, Projectile at 20 in. 


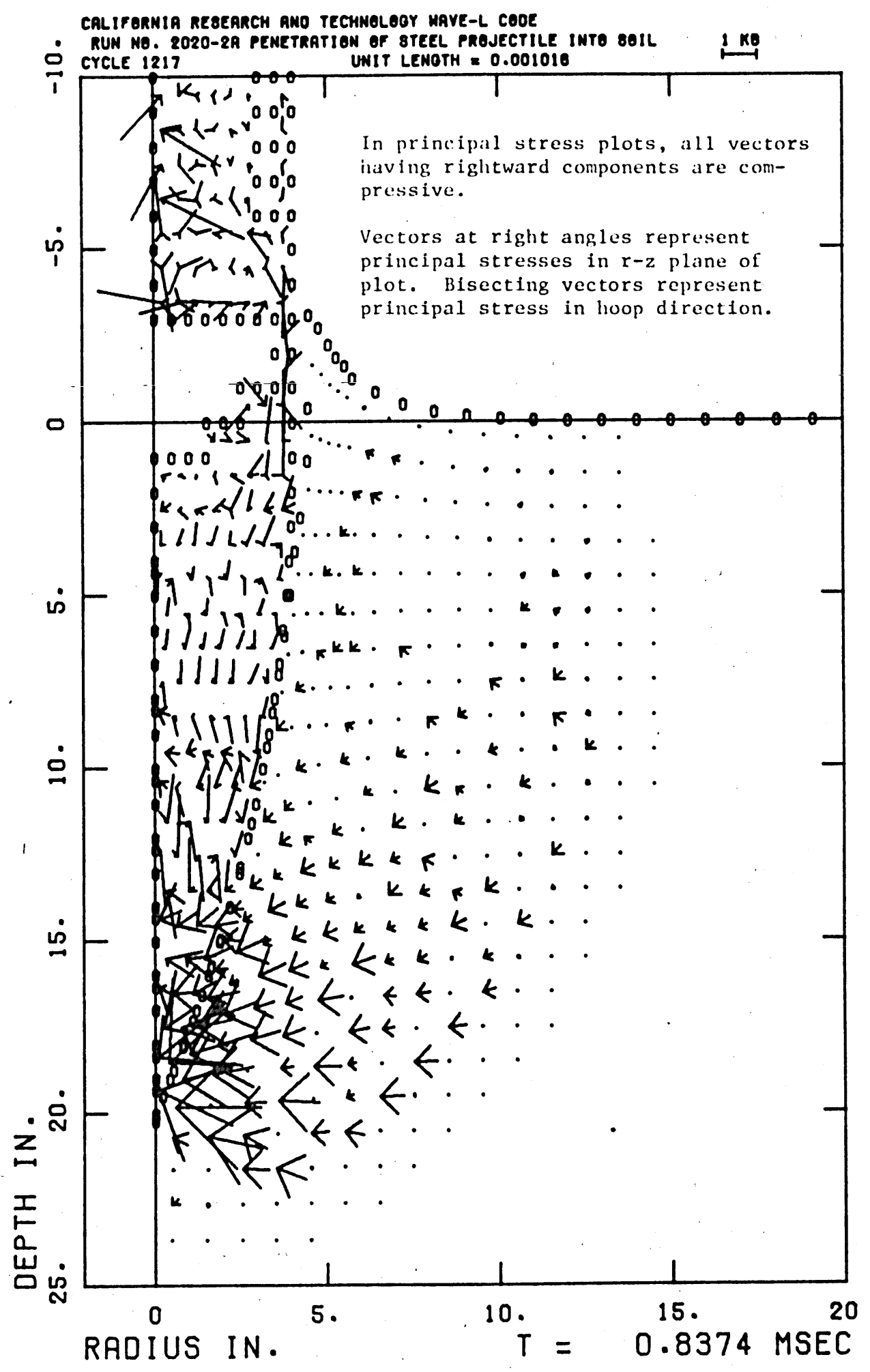

Figure B-20. Principal Stress Field at End of DeformableBody Solution, Projectile at 20 in. Depth 


\section{APPENDIX C}

\section{DISTORTION, VELOCITY, AND PRINCIPAL STRESS}

FIELD PLOTS - RIGID-BODY SOLUTION

A series of field plots of the computational grid, particle velocities, and principal stresses which illustrate the soil response during the rigid-body solution were prepared. These are shown for the following penetration depth and times:

\begin{tabular}{|r|c|ccc|}
\hline $\begin{array}{l}\text { Depth } \\
\text { (ft) }\end{array}$ & $\begin{array}{c}\text { Time } \\
\text { (msec) }\end{array}$ & $\begin{array}{c}\text { Figure No. of Plot for: } \\
\text { Distortion } \\
\text { (Grid) }\end{array}$ & Velocity & Stress \\
\hline \multicolumn{1}{|c|}{} & \multicolumn{1}{|c|}{ C -1} & $\mathrm{C}-2$ & $\mathrm{C}-3$ \\
.84 & .17 & $\mathrm{C}-4$ & $\mathrm{C}-5$ & $\mathrm{C}-6$ \\
1.67 & .42 & $\mathrm{C}-7$ & $\mathrm{C}-8$ & $\mathrm{C}-9$ \\
5.00 & 2.54 & $\mathrm{C}-10$ & $\mathrm{C}-11$ & $\mathrm{C}-11$ \\
10.00 & 5.08 & $\mathrm{C}-13$ & $\mathrm{C}-14$ & $\mathrm{C}-15$ \\
15.00 & 7.69 & $\mathrm{C}-16$ & $\mathrm{C}-17$ & $\mathrm{C}-18$ \\
16.92 & 8.70 & $\mathrm{C}-19$ & $\mathrm{C}-20$ & $\mathrm{C}-21$ \\
22.31 & 11.58 & $\mathrm{C}-22$ & $\mathrm{C}-23$ & $\mathrm{C}-24$ \\
\hline
\end{tabular}

The plots of the grid also show which material is currently failing; i.e., is on the yield surface. This is denoted by cells containing an $x$ or + , with $x$ indicating a compressive pressure, $P \geq 0$, and + indicating hydrostatic tension, $\mathrm{P}<0$.

The velocity vector field plots show the direction and magnitude of the particle velocity at each lattice point in 
the computing grid. For clarity in viewing the soil response, the velocity vectors of the projectile are not shown.

The plotting convention for the principal stress field plots is the same as that used in the deformable-body solution (Appendix B). 


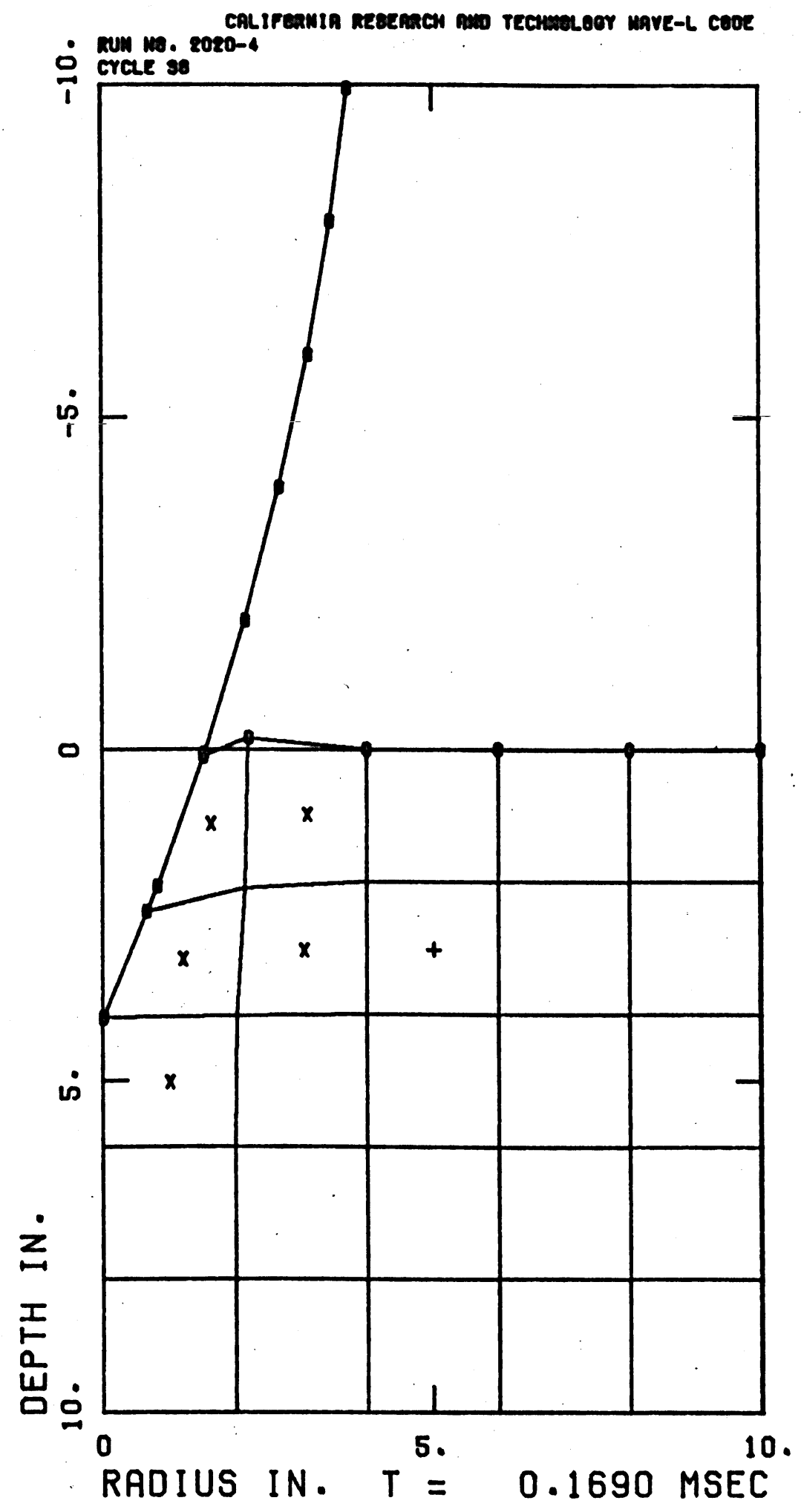

Figure $\mathrm{C}-1$. Grid Configuration with Projectile at $4 \mathrm{in.} \mathrm{Depth}$ 


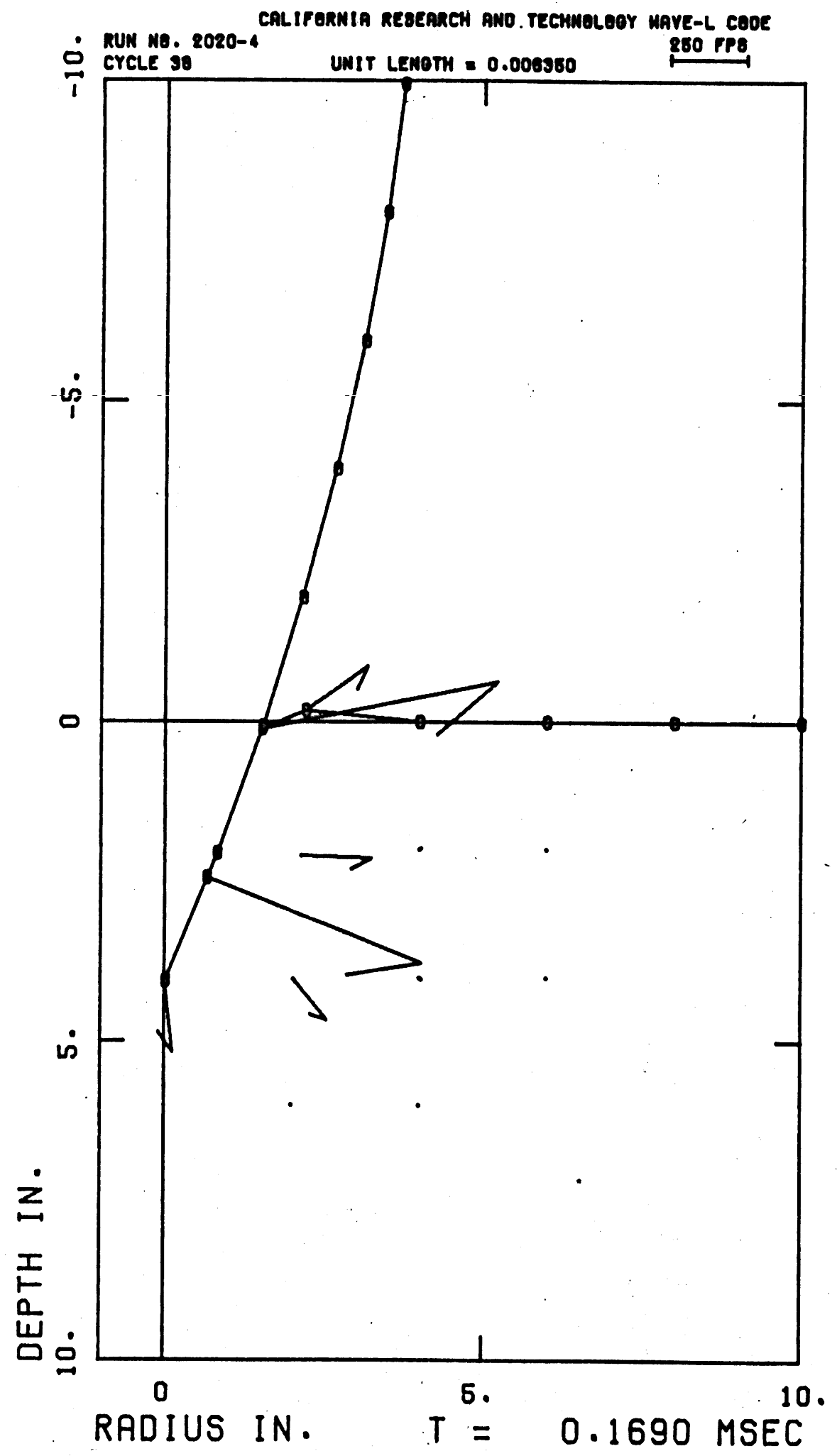

Figure C-2. Particle Velocity Field with Projectile at 4 in. Depth

108 


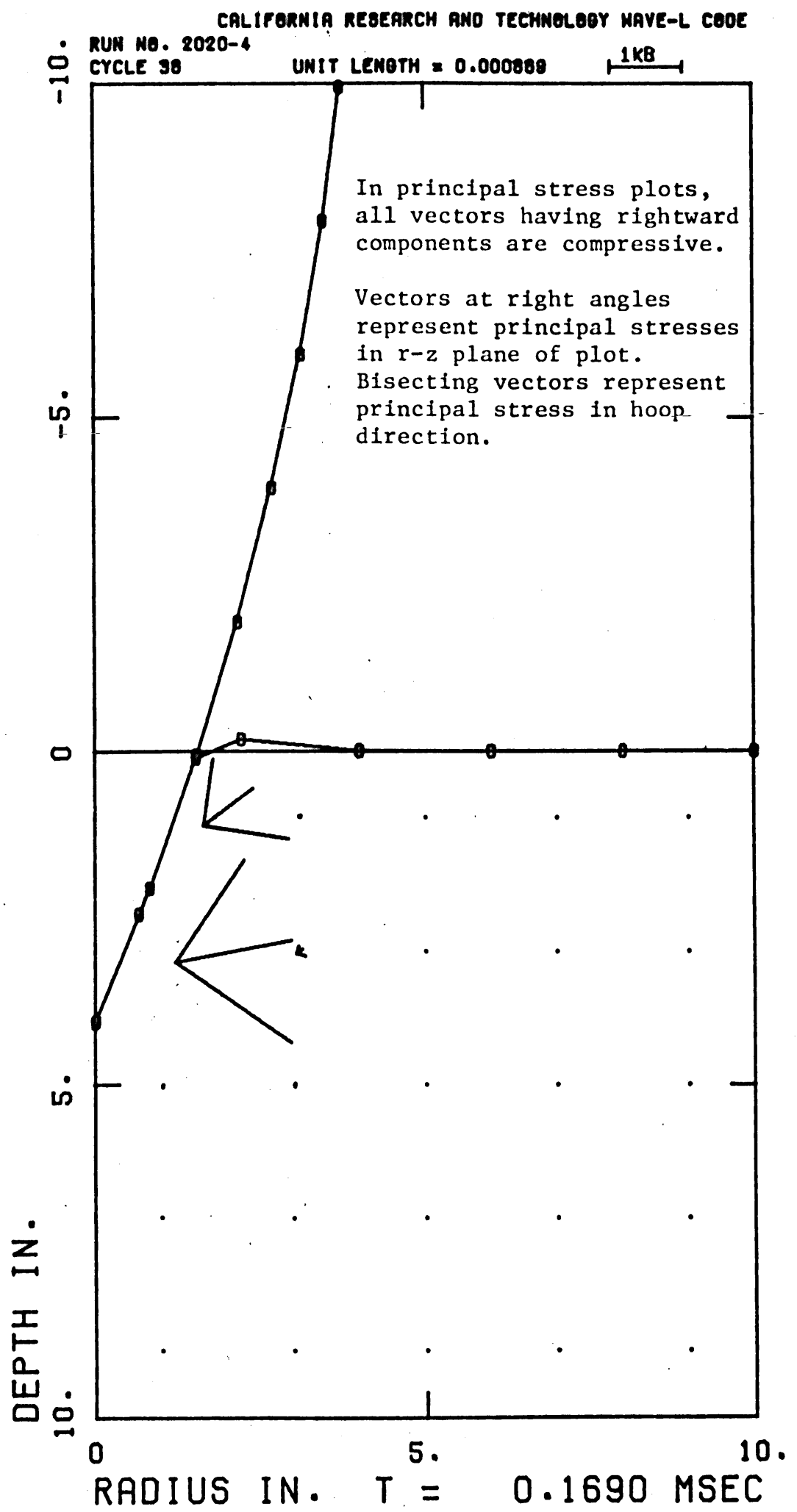

Figure C-3. Principal Stress Fleld with Projectile at 4 in. Depth 


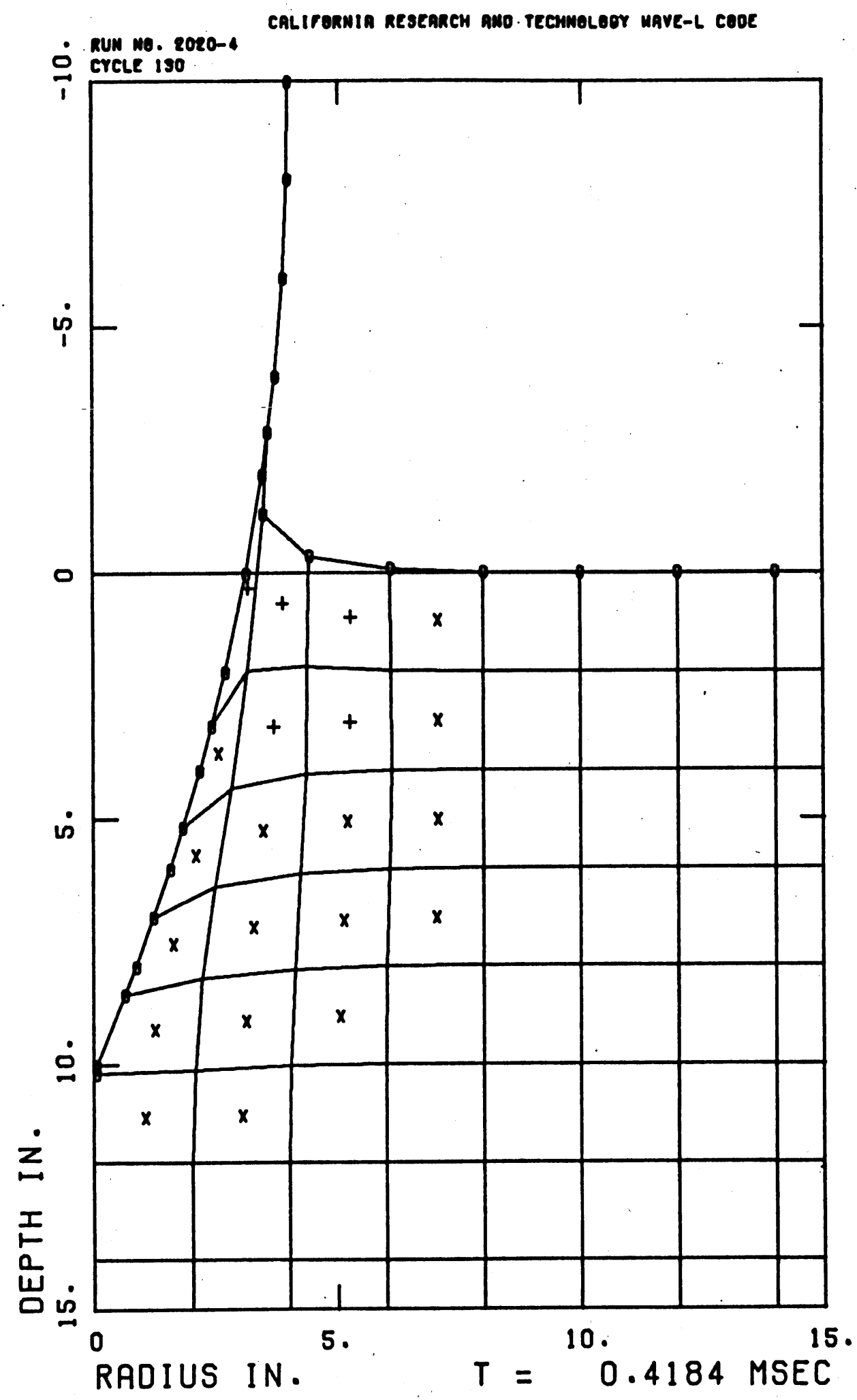

Figure C-4. Grid Configuration with Projectile at 10 in. Depth 


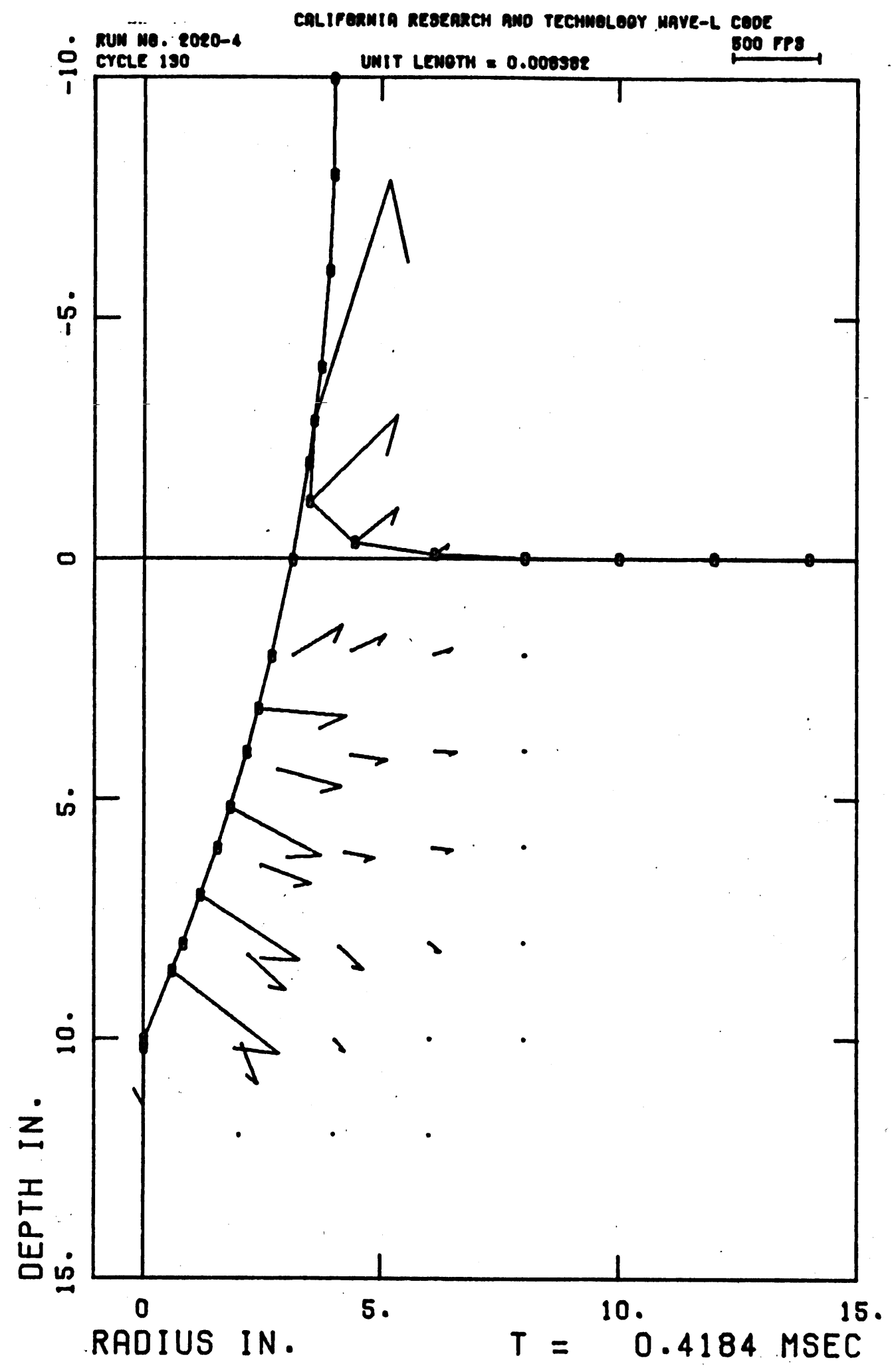

Figure C-5. Particle Velocity Field with Projectile at 10 in. Depth 


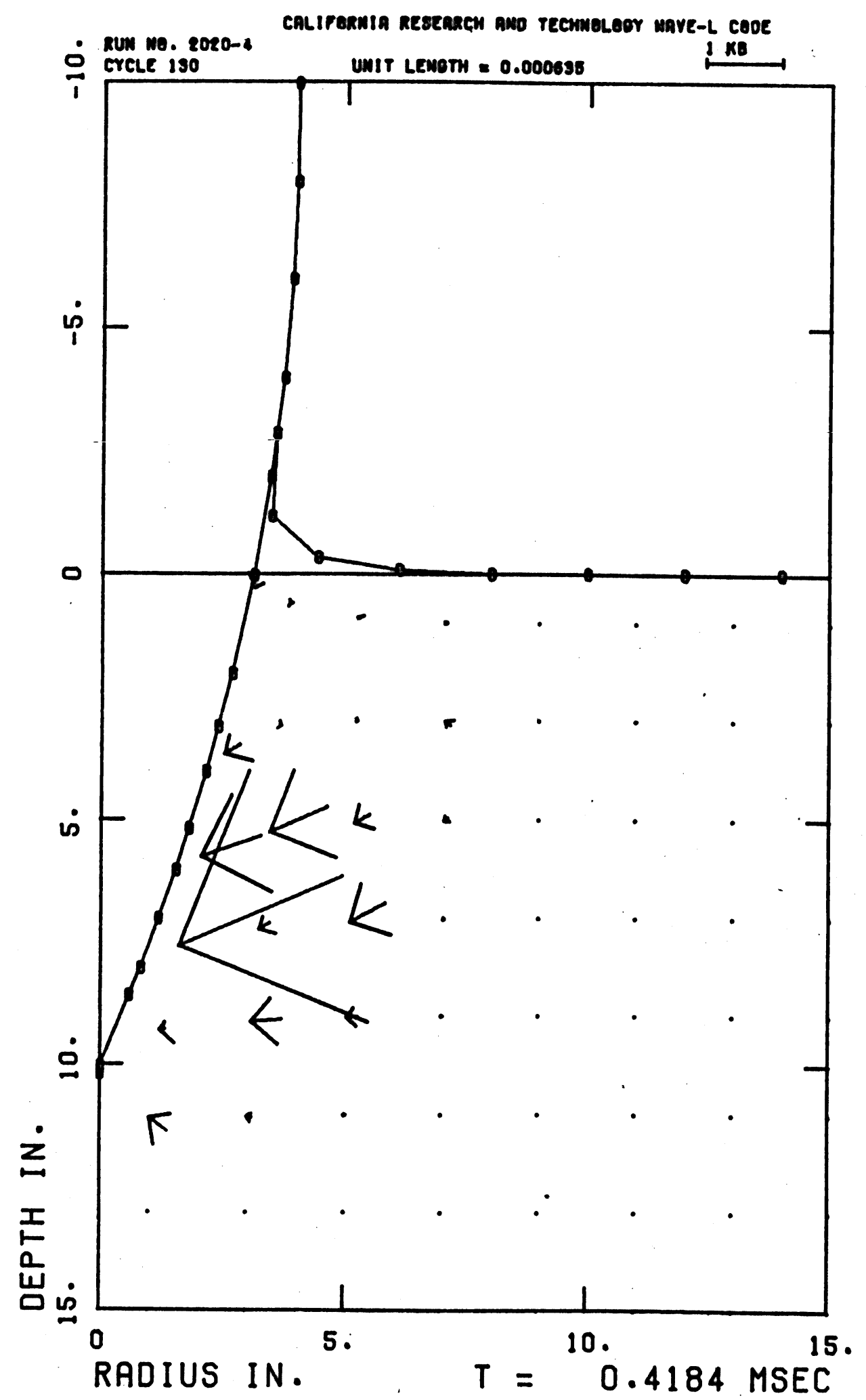

Figure C-6. Principal Stress Field with Projectile at 10 in. Depth

112 


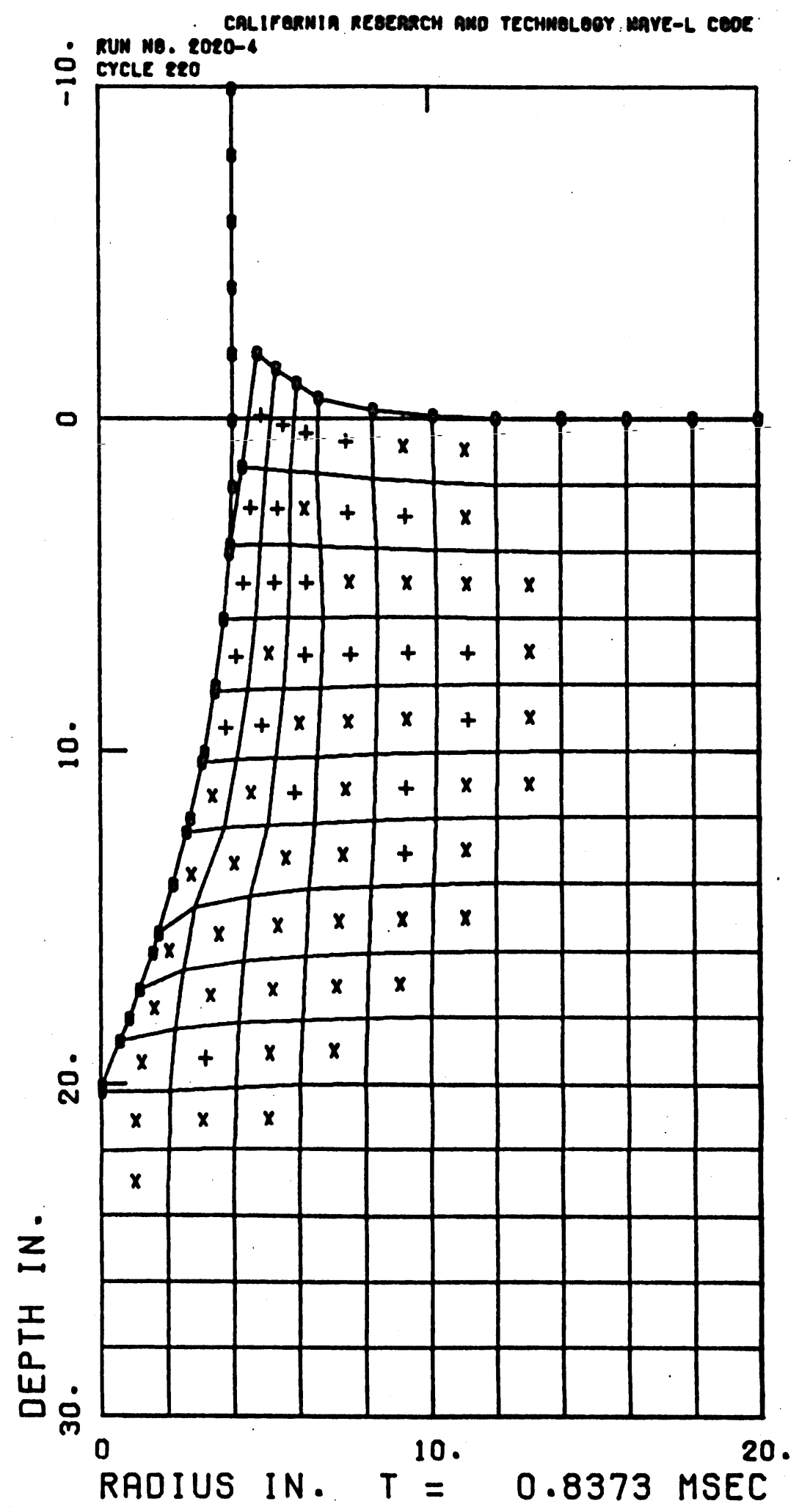

Figure C-7. Grid Configuration with Projectile at 20 in. Depth 


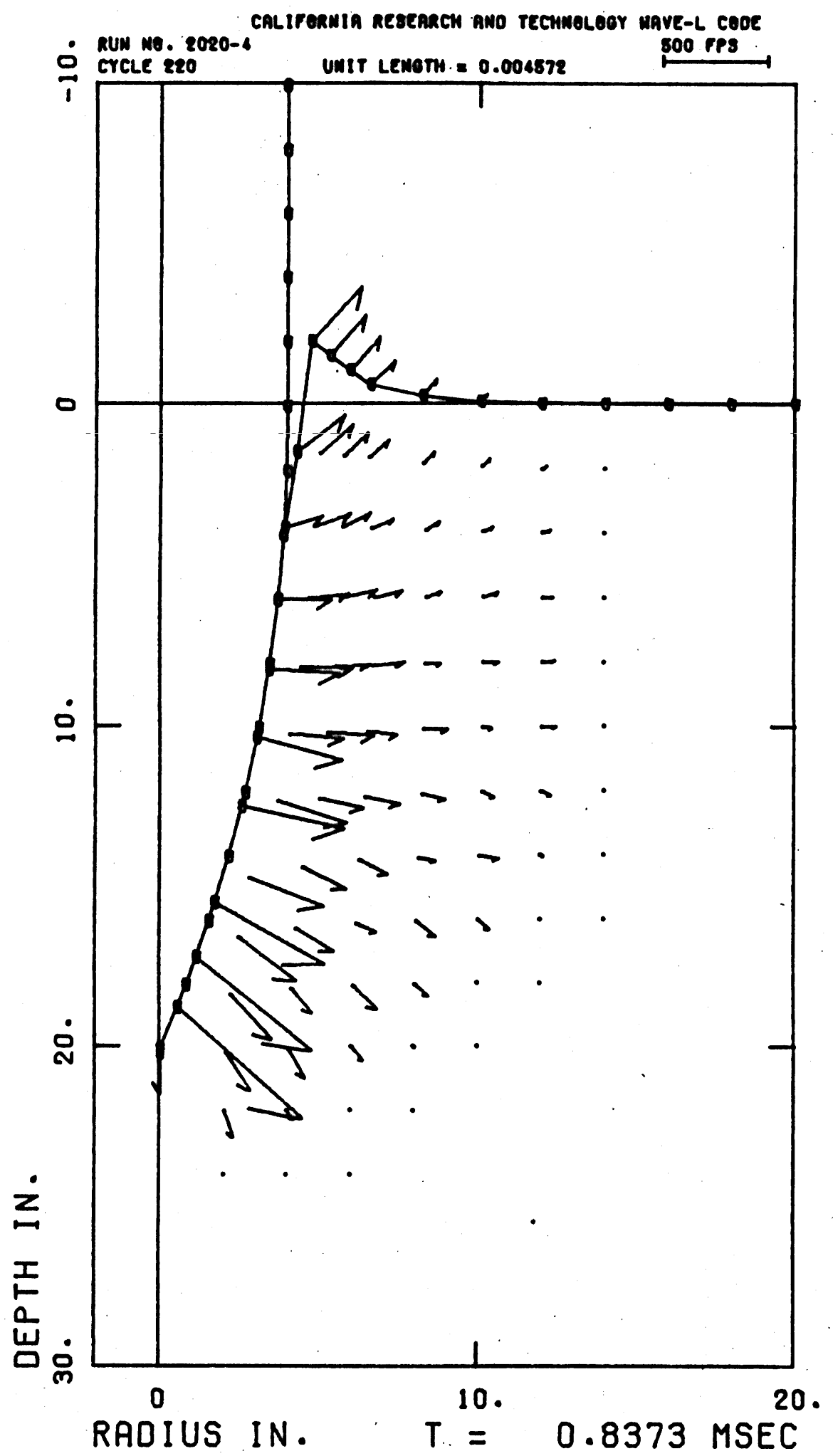

Figure C-8. Particle Velocity Field with Projectile at 20 in. Depth

114 


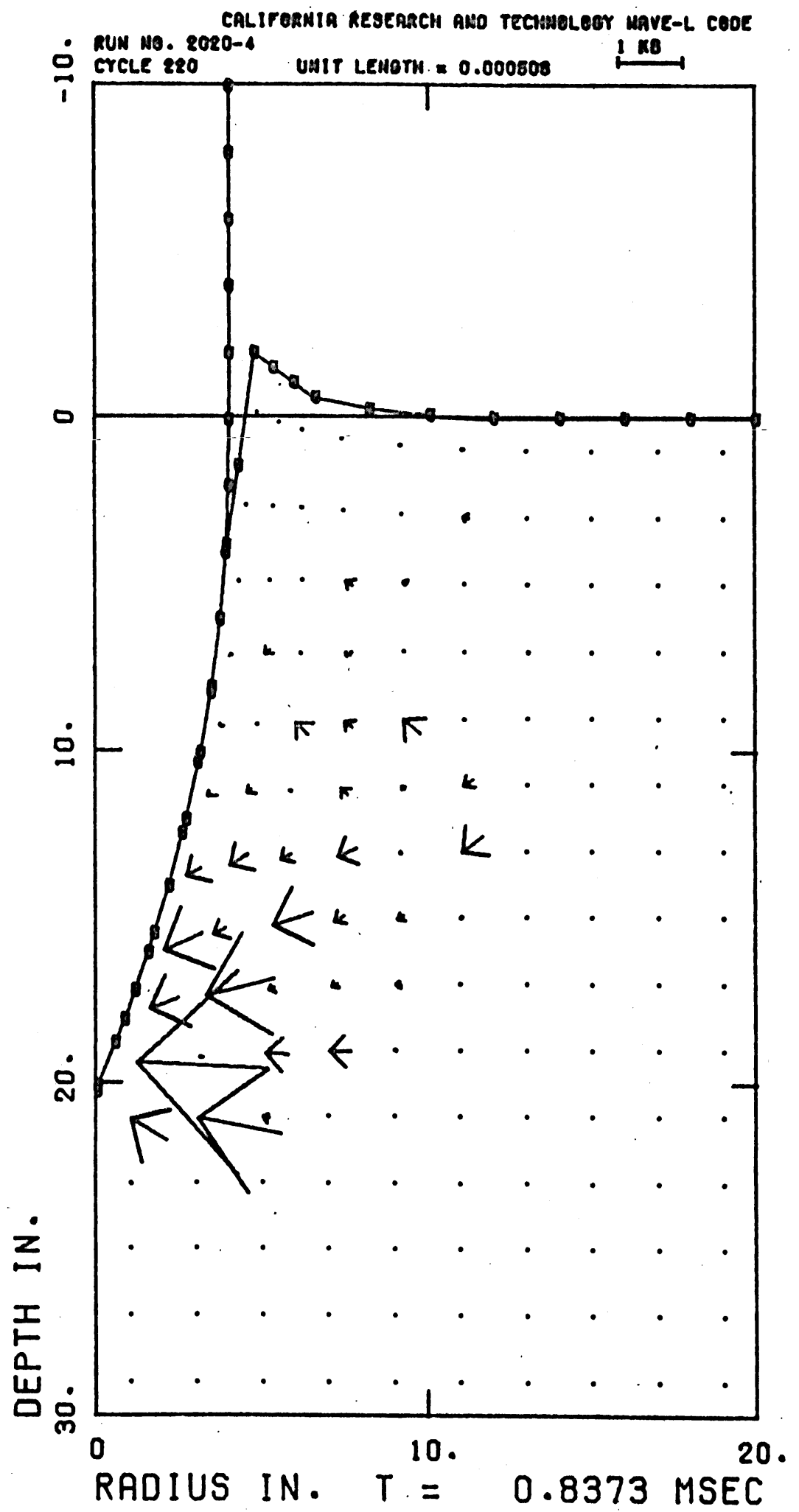

Figure C-9. Principal Stress Field with Projectile at 20 in. Depth 


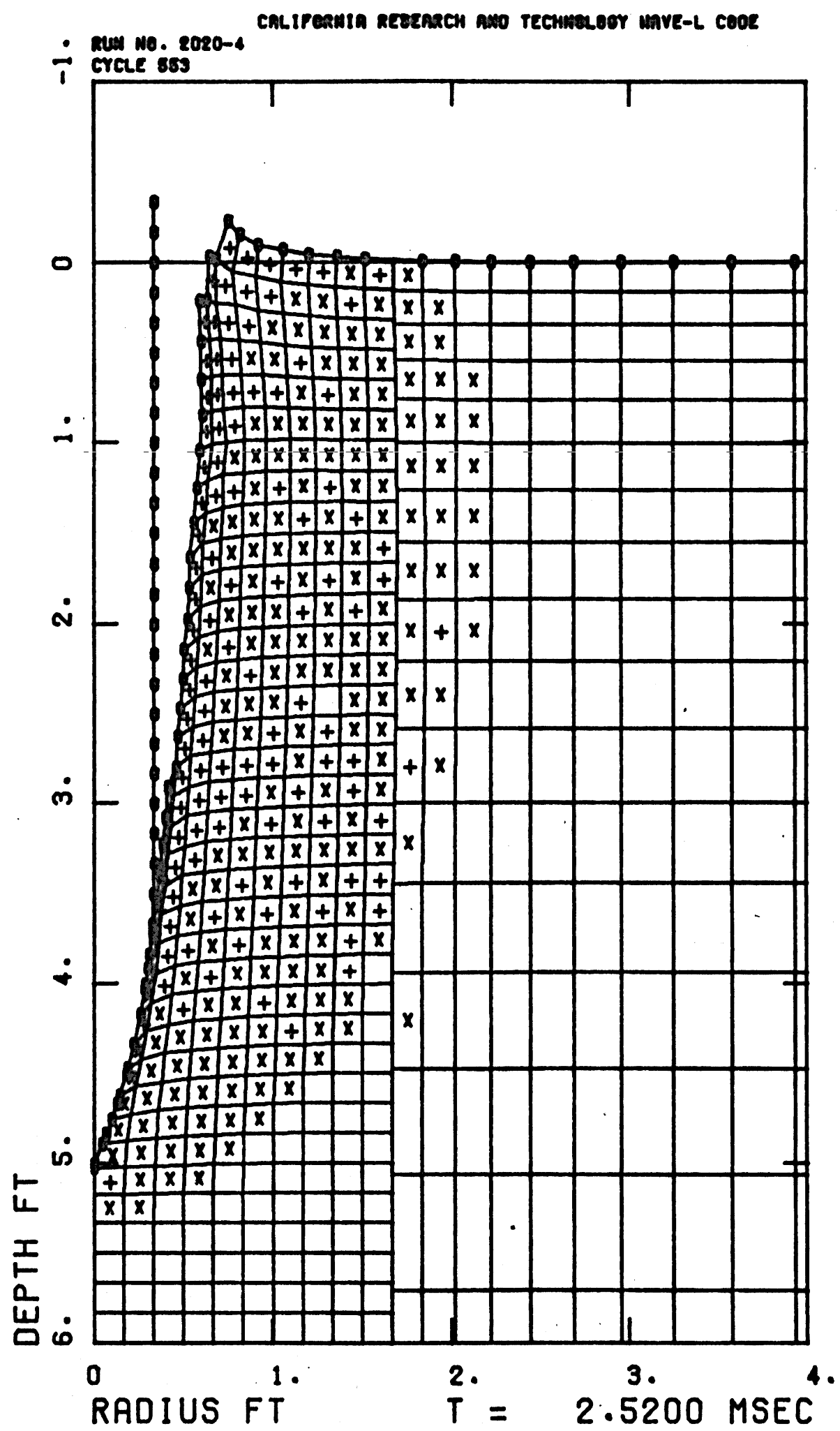

Figure C-10. Grid Configuration with Projectile at $5 \mathrm{ft}$ Depth 


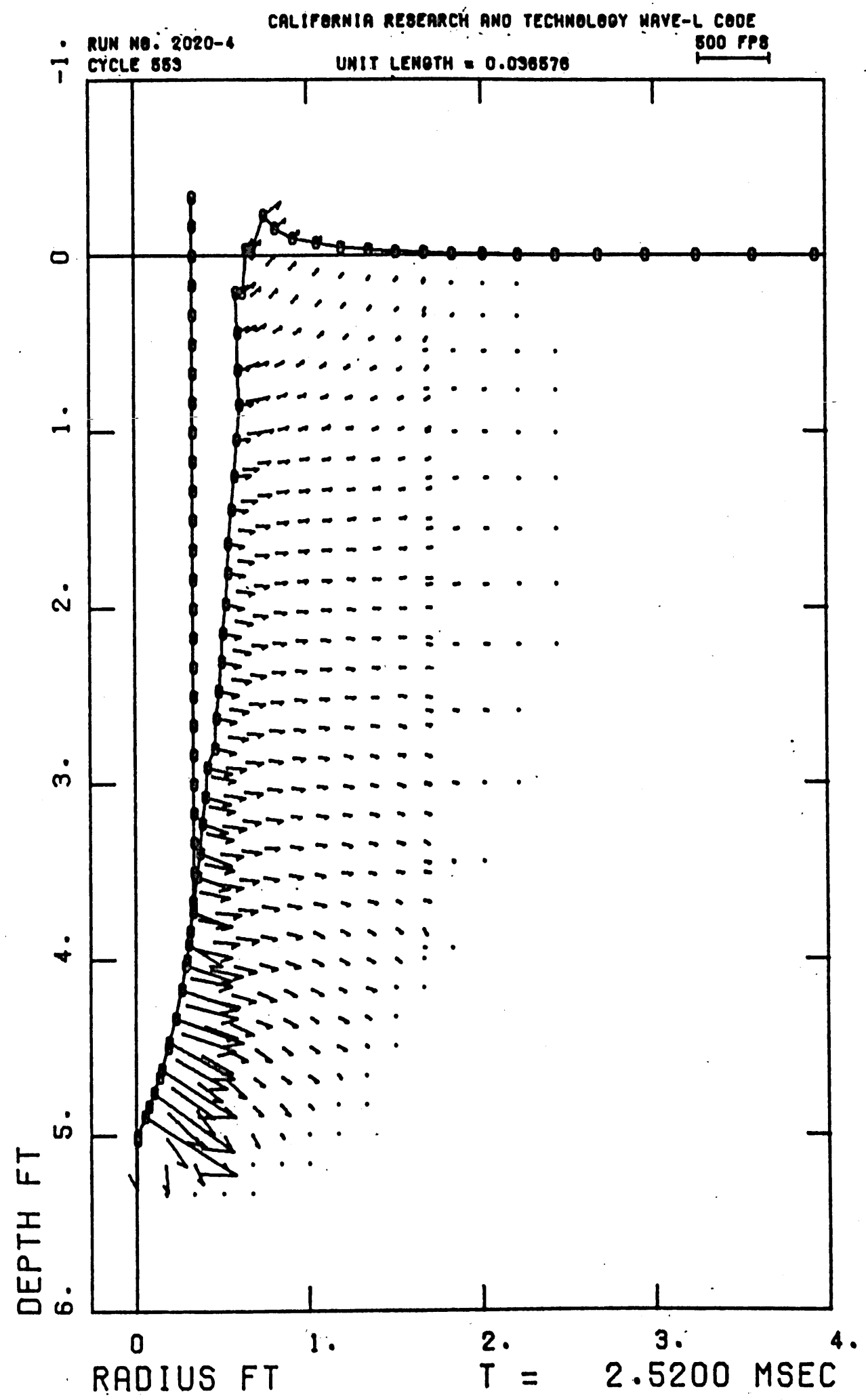

Figure C-11. Particle Velocity Field with Projectile at $5 \mathrm{ft}$ Depth 


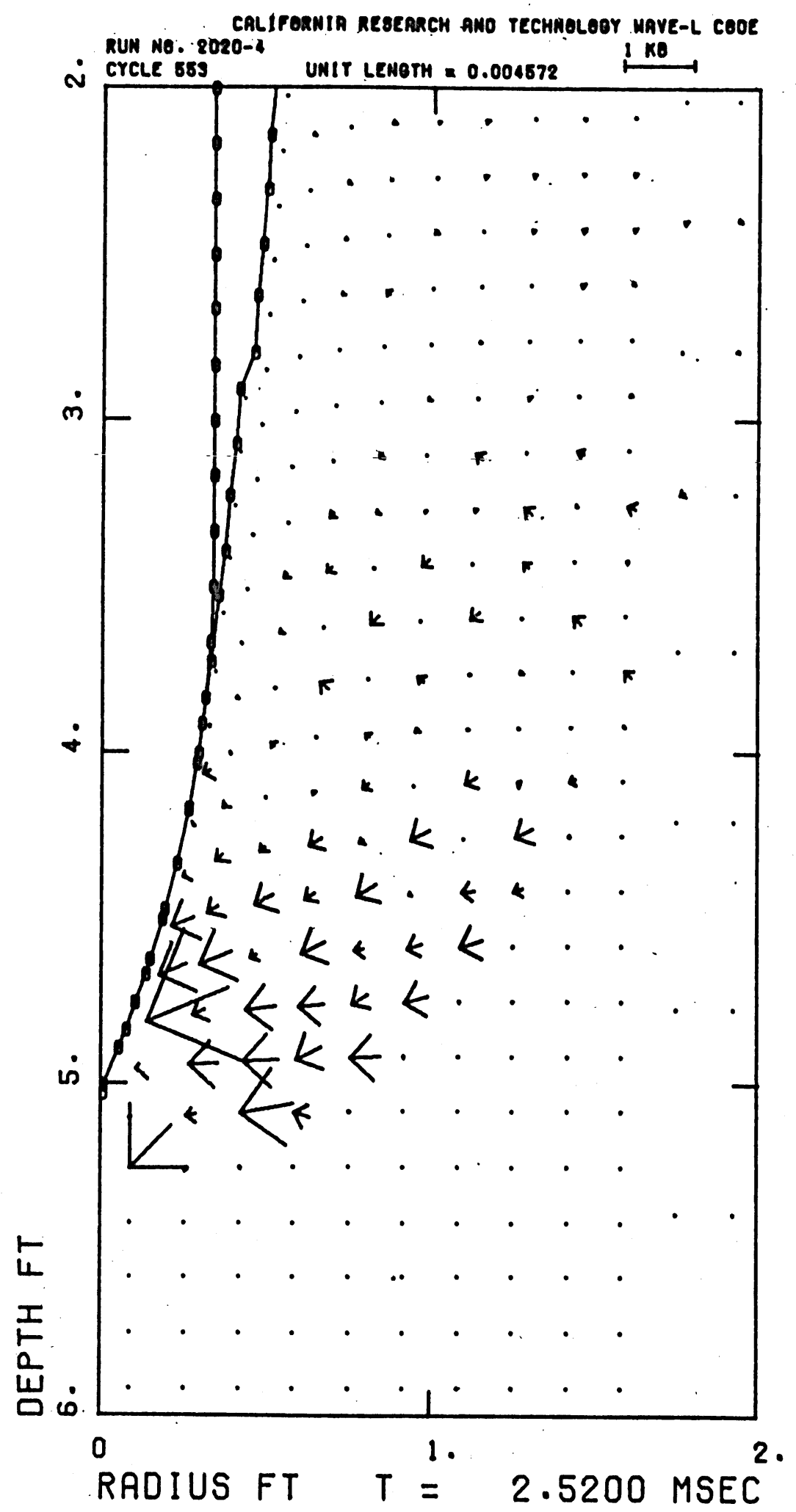

Figure C-12. Principal Stress Field with Projectile at $5 \mathrm{ft}$ Depth 


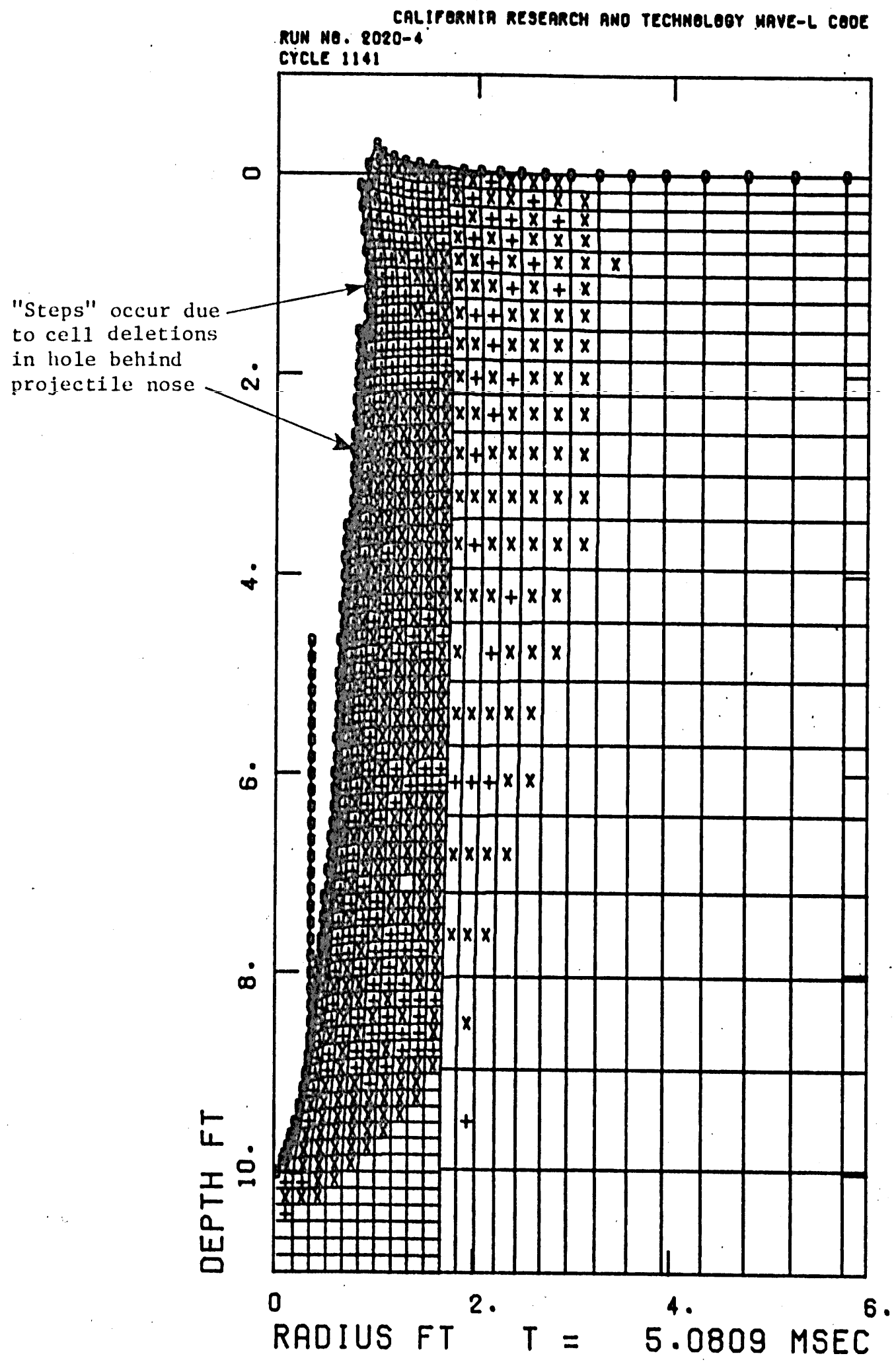

Figure C-13. Grid Configuration with Projectile at $10 \mathrm{ft}$. Depth 


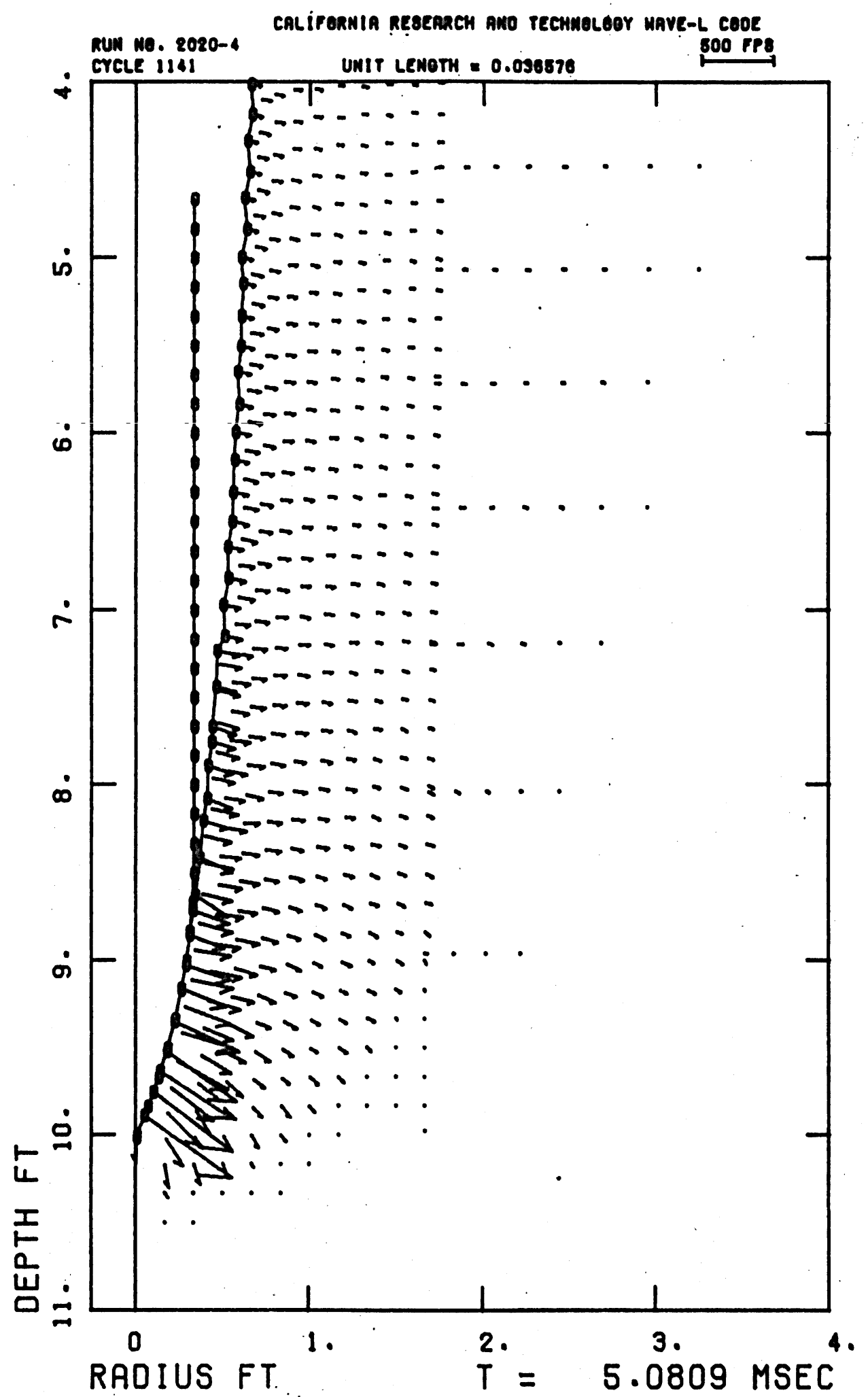

Figure C-14. Particle Velocity Field with Projectile at $10 \mathrm{ft}$. Depth 


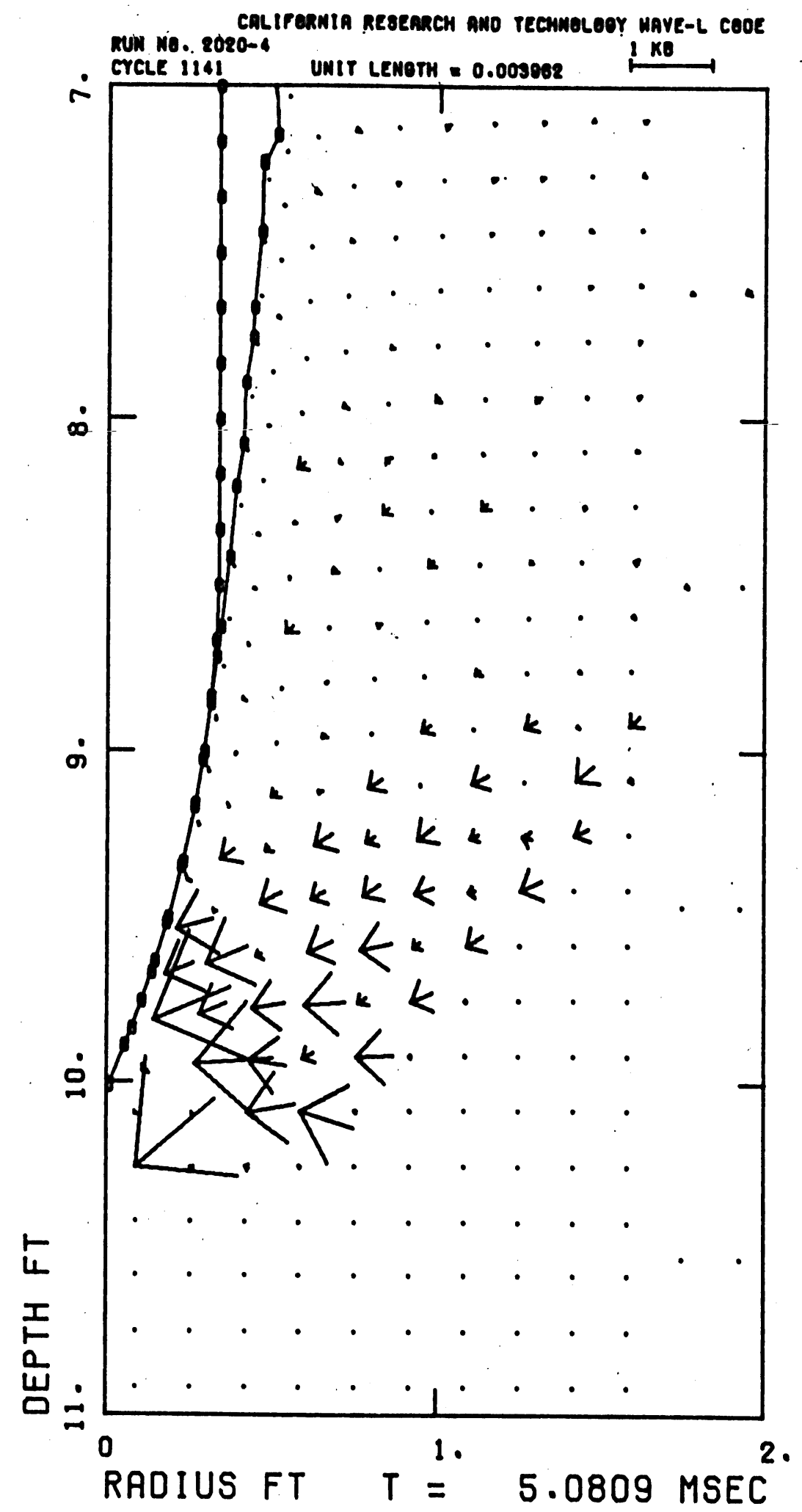

Figure C-15. Principal Stress Field with Projectile at $10 \mathrm{ft}$. Depth

121 


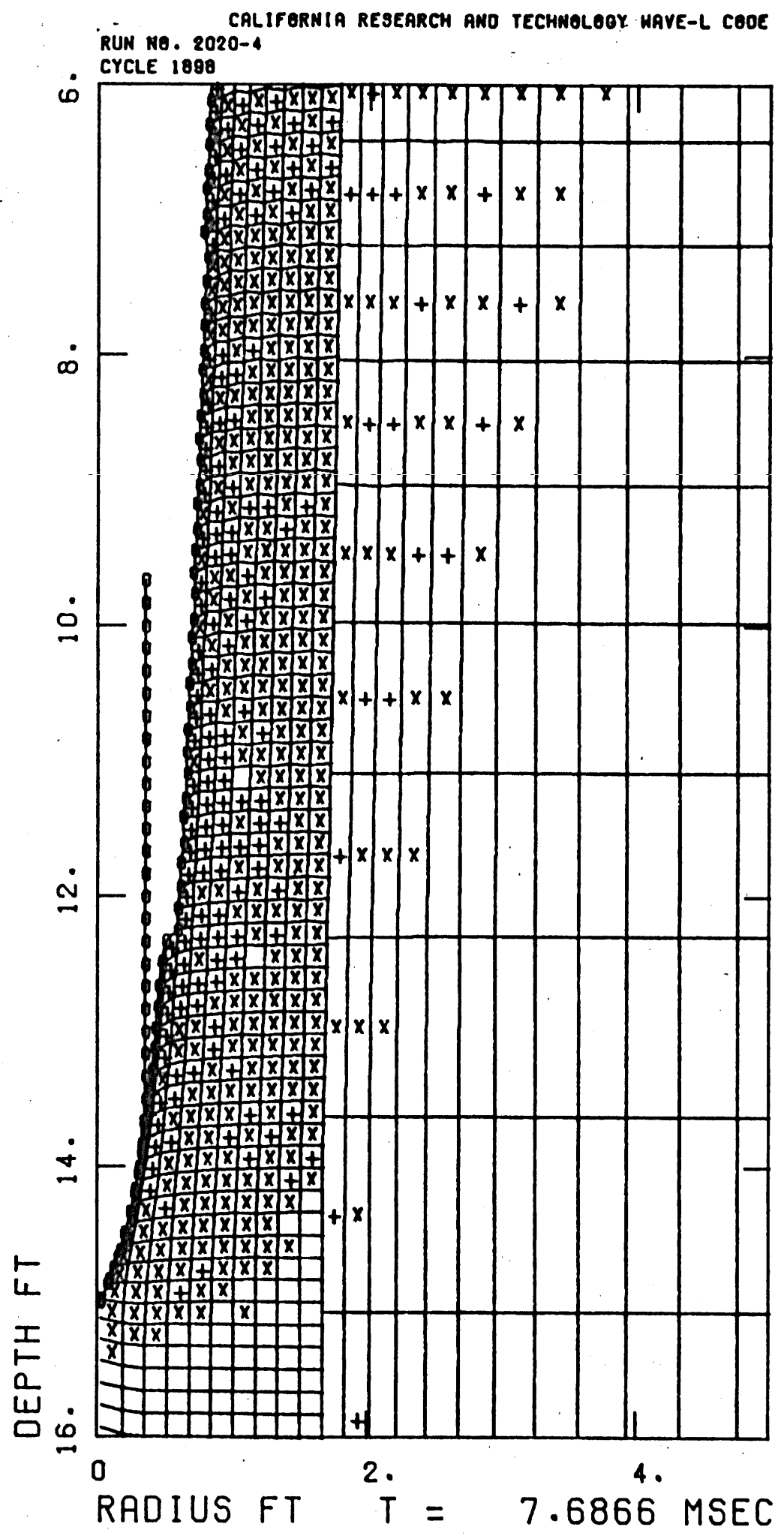

Figure C-16. Grid Configuration with Projectile at $15 \mathrm{ft}$ Depth 


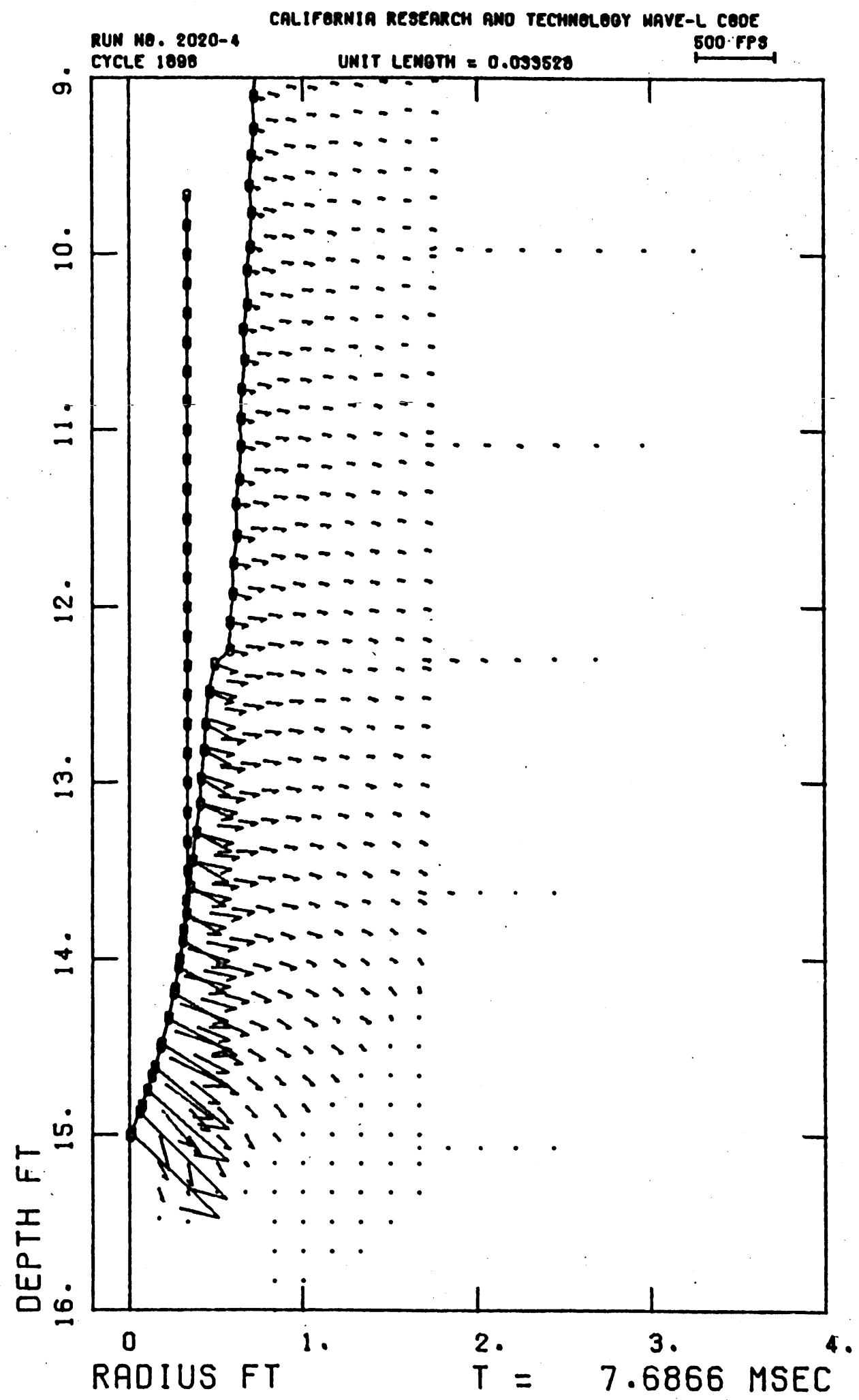

Figure C-17. Particle Velocity Field with Projectile at $15 \mathrm{ft}$ Depth 


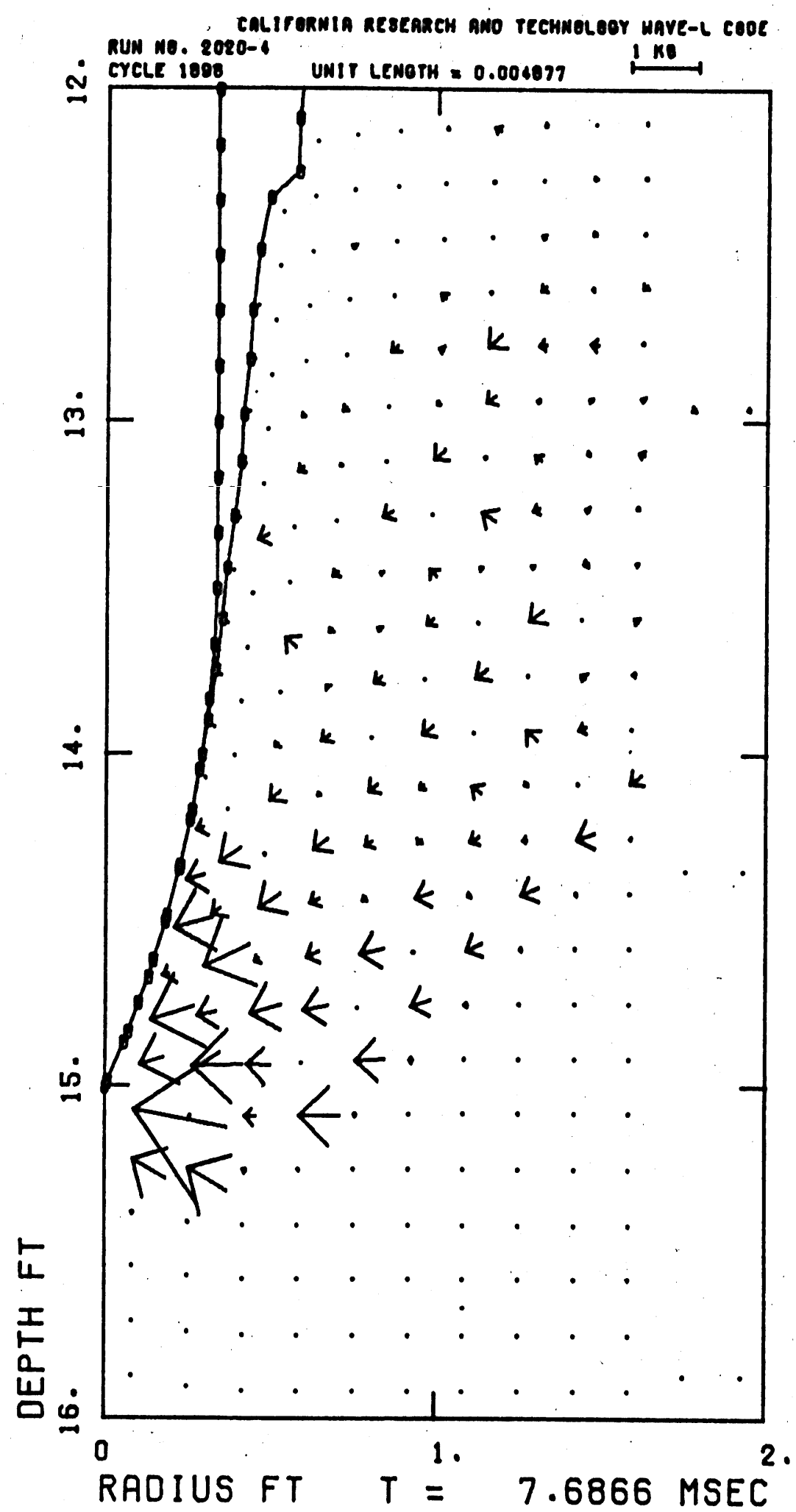

Figure C-18. Principal Stress Field with Projectile at $15 \mathrm{ft}$. Depth 


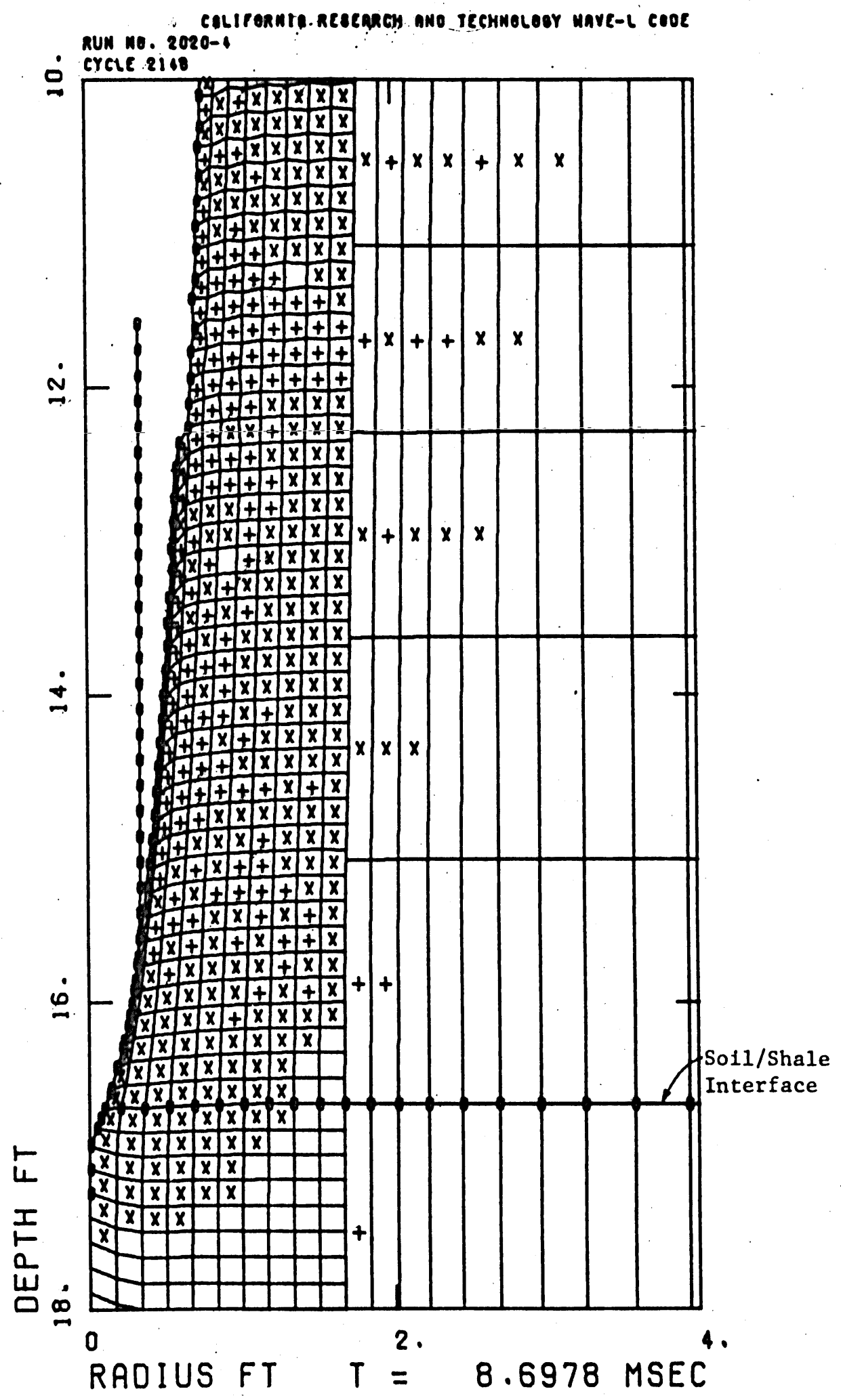

Figure C-19. Grid Configuration with Profectile at $16.9 \mathrm{ft}$ Depth 


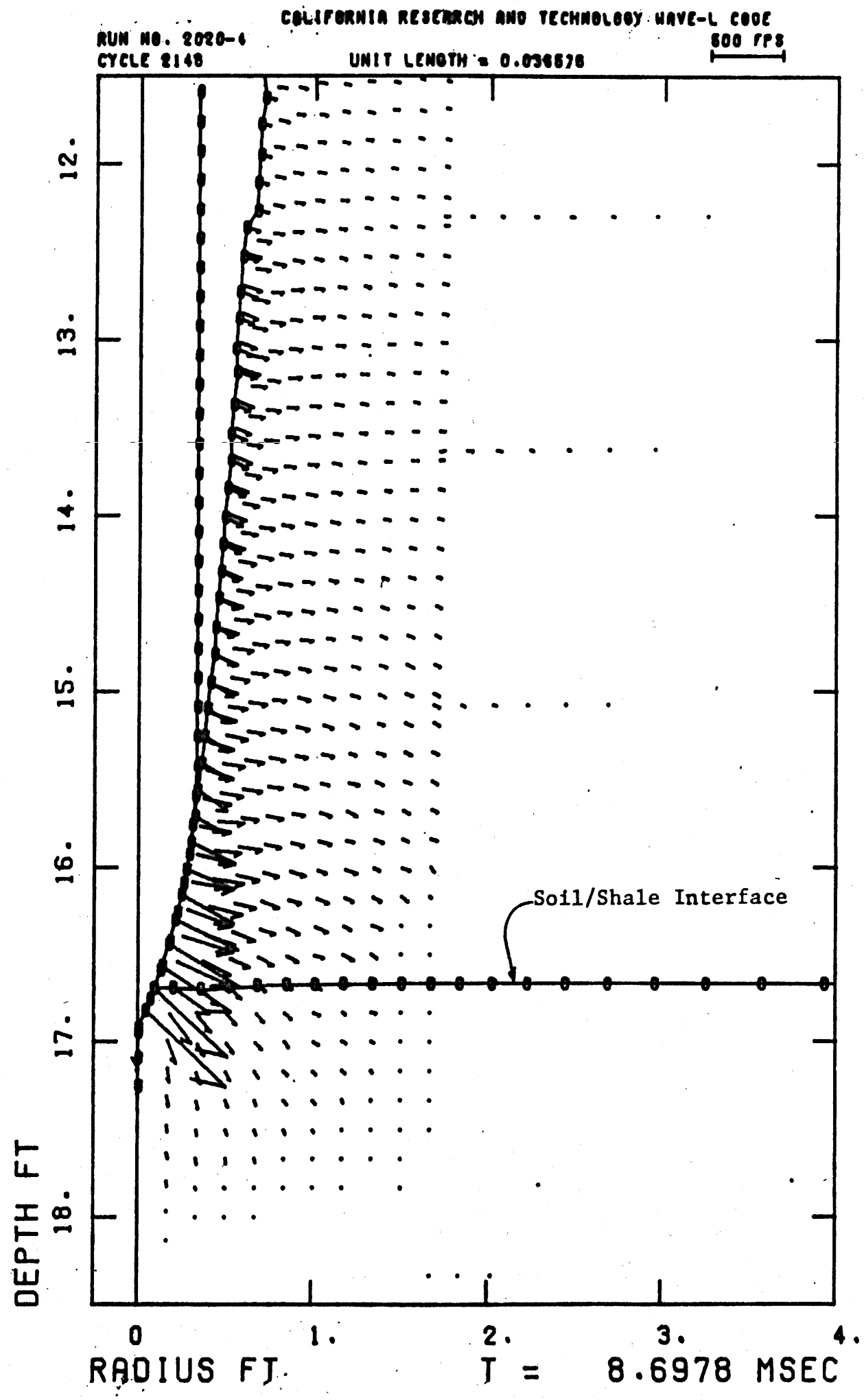

Figure C-20. Particle Velocity Field with Projectile at $16.9 \mathrm{ft}$ Depth 


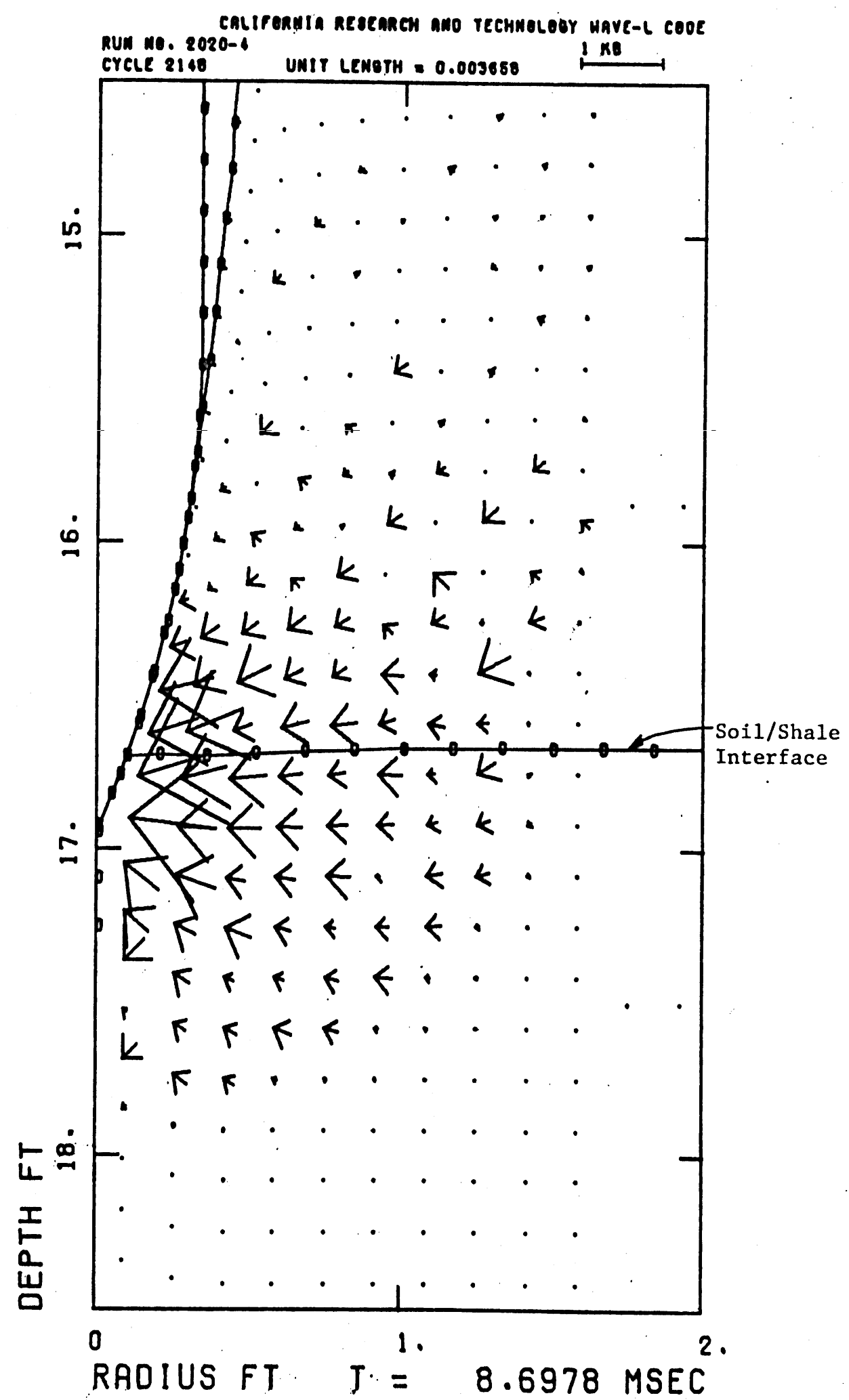

Figure C-21. Principal Stress Field with Projectile at $16.9 \mathrm{ft}$ Depth 


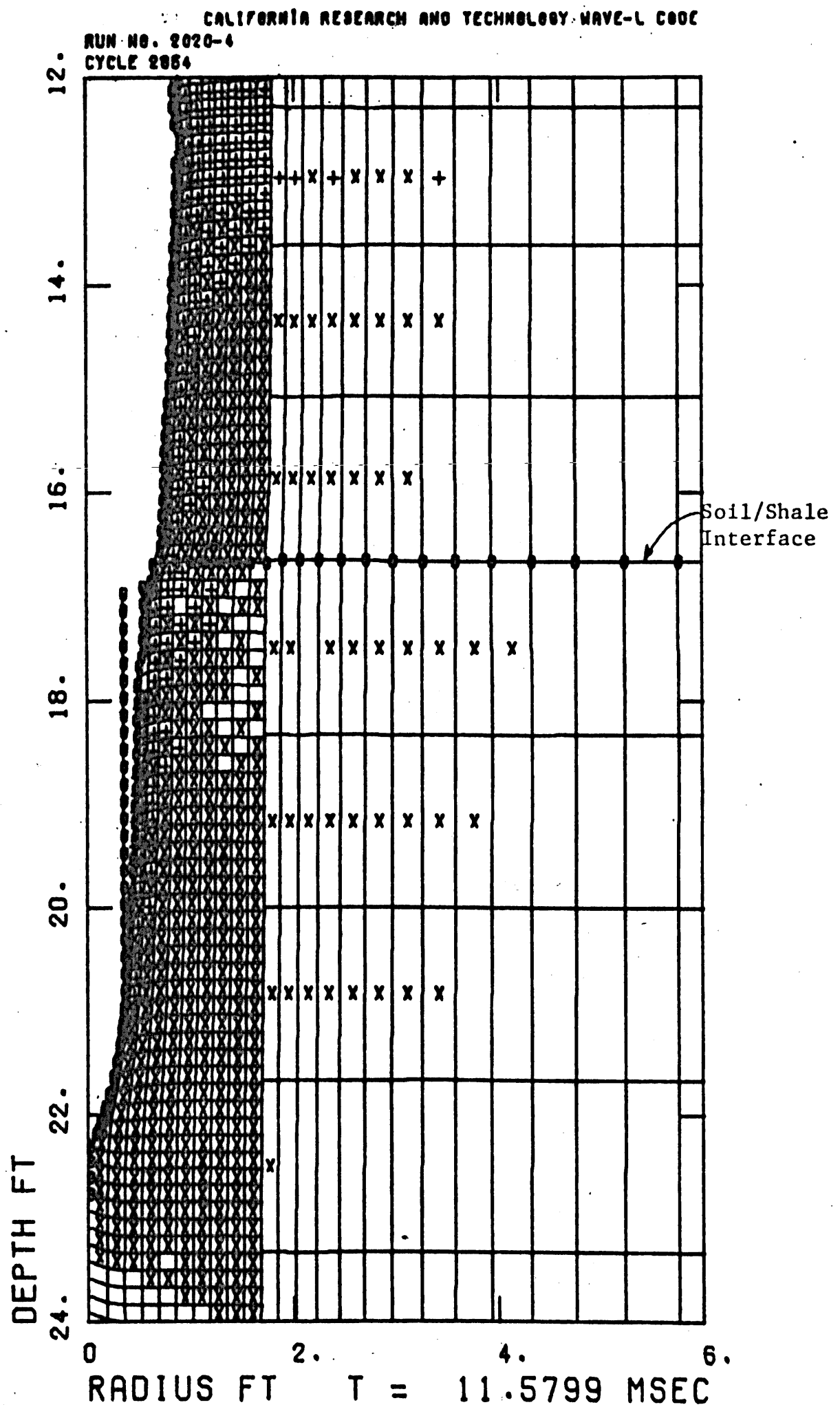

Figure C-22. Grid Configuration at End of Rigid-Body Solution, Projectile at $22.3 \mathrm{ft}$ Depth 


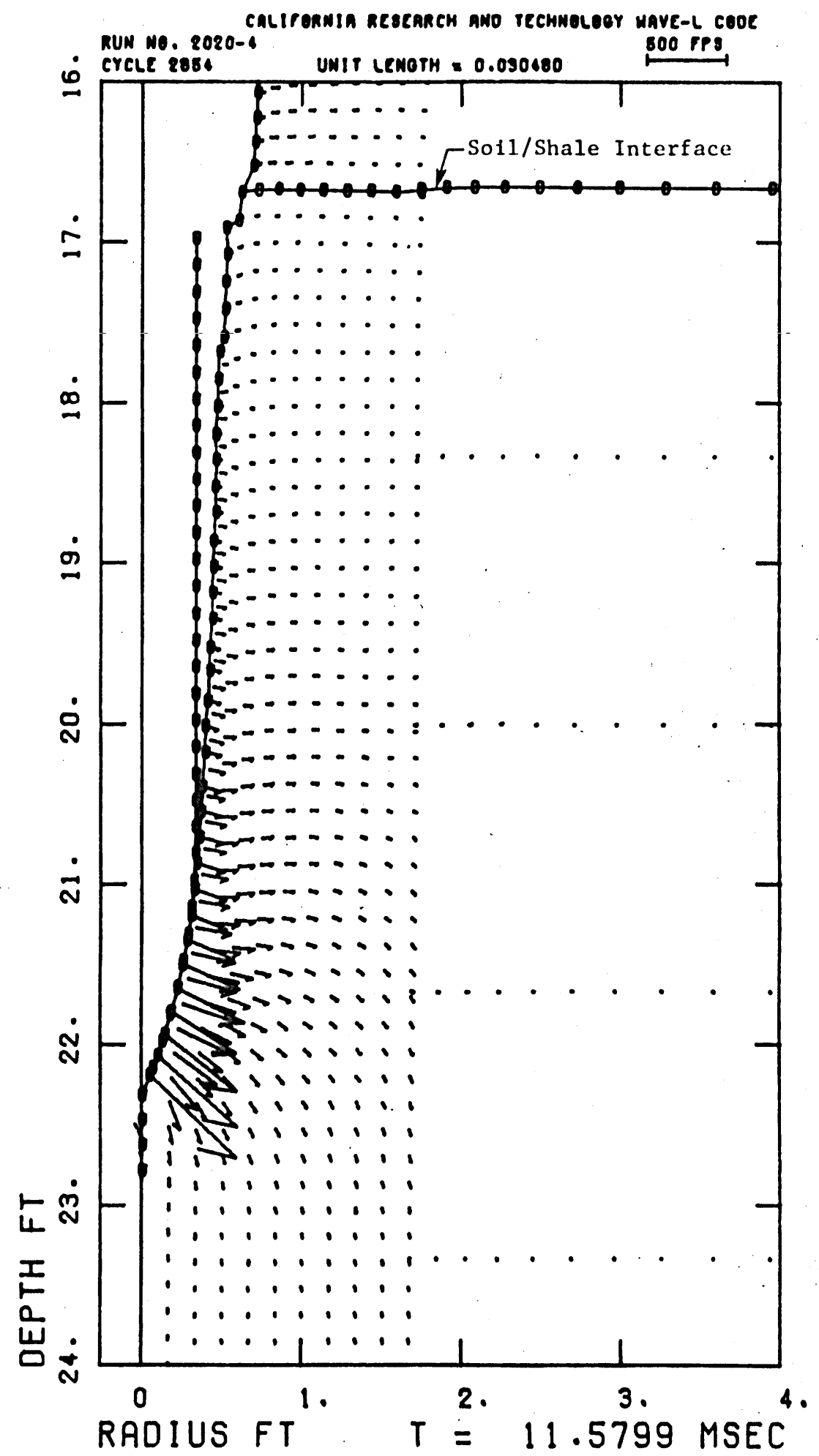

Figure C-23. Particle Velocity Field at End of Rigid-Body Solution, Projectile at $22.3 \mathrm{ft}$ Depth 


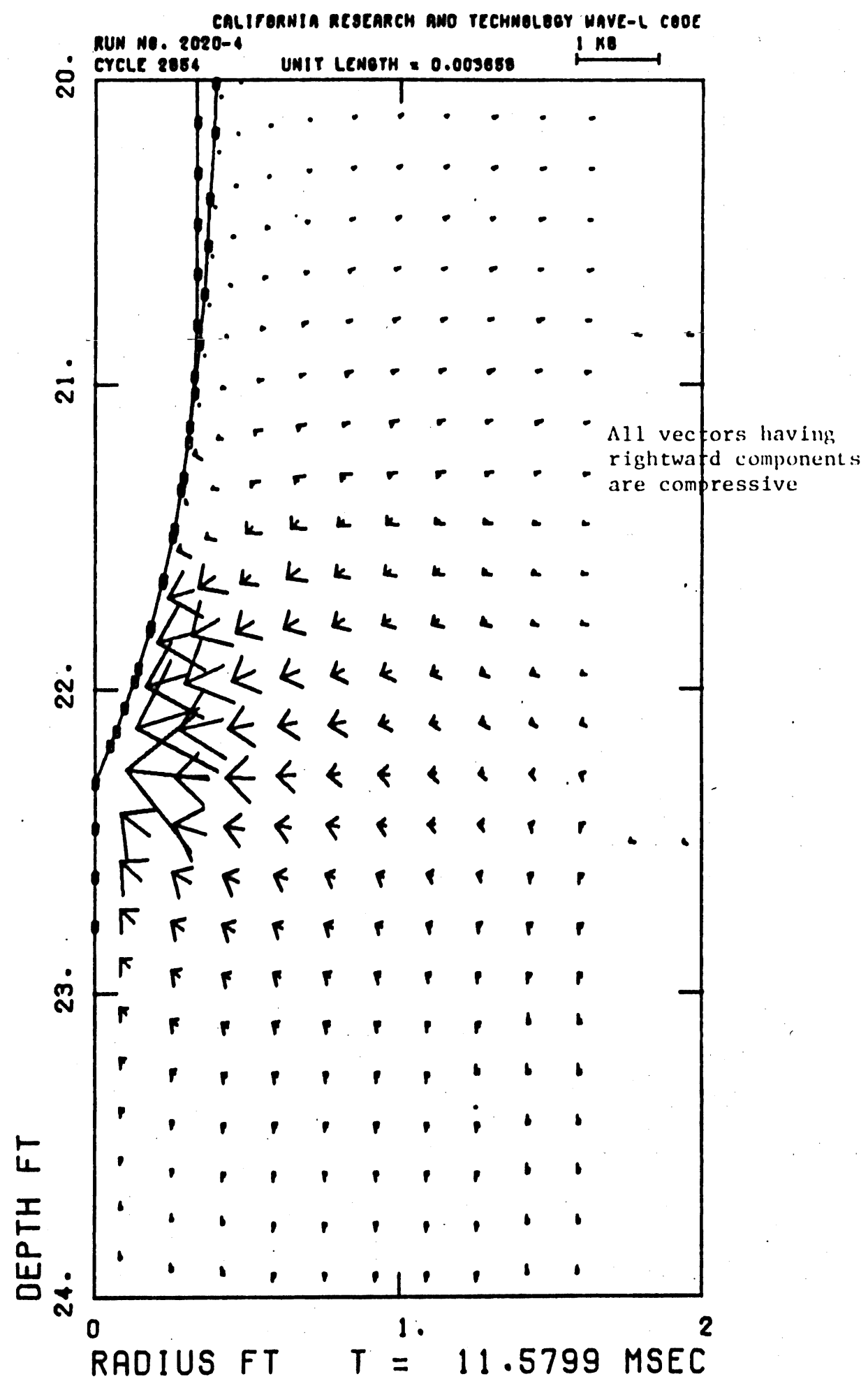

Figure C-24. Principal Stress Field at End of Rigid-Body Solution, Projectile at $22.3 \mathrm{ft}$ Depth 
$\underline{\mathrm{DOD}}$

Assistant to the Secretary of Defense, Atomic Energy,

Washington, D. C. 20301

ATTN: Donald R. Cotter

Director, Defense Advanced Research Projects Agency, Architect Building, 1400 Wilson Blvd., Arlington, Virginia 22209

ATTN: Technical Library

PMO

STO

Defense Documentation Center, Cameron Station, Alexandria, Virginia 22314

ATTN: TC/Myer B. Kahn

Director, Defense Intelligence Agency, Washington,

D. C. 20301

ATTN: DT-2, Weapons \& Systems Division

DI-7D, Phys. Vul. Div., Edward O'Farrel1

$\mathrm{DI}-7 \mathrm{E}$

Technical Library

Director, Defense Nuclear Agency, Washington, D. C. 20305

ATTN: STTL (Technical Library)

STSI (Archives)

DDST

SPSS

Director of Defense Research and Engineering, Washington,

D. C. 20301

ATTN: Deputy Director, Tactical Warfare

Deputy Director, Strategic Systems

Assistant Director, Strategic Weapons

M. J. Minneman

George Barse

Craig W. Hartsel1

R. Thorkildsen

Commander, Field Command, Defense Nuclear Agency, Kirtland

Air Force Base, New Mexico 87115

ATTN: FCTA

FCTA-D 
DOD (Continued)

Interservice Nuclear Weapons School, Kirtland Air Force Base, New Mexico 87115

ATTN: Technical Library

Director, Joint Strategic Target Planning Staff, JCS, Offutt Air Force Base, Nebraska 68113

ATTN: Science and Technology Info Library

$\underline{\text { Army }}$

Assistant Chief of Staff for Force Development, Department of the Army, Washington, D. C. 20310

ATTN: Director of Chem \& Nuc Ops

Technical Library

Headquarters, Central Army Group, APO New York 09099

ATTN: CENEN LTC J. L. Spruill

Office, Chief of Engineers, Department of the Army,

Washington, D. C. 20314

ATTN: DAEN-RDM

DAEN-MCE-D

DAEN-RDZ-A/W. B. Taylor

Office, Chief of Research, Development, and Acquisition,

Department of the Army, Washington, D. C. 20310

ATIN: DAMA-CSM/LTC Edward V. DeBoesser, Jr. Technical Library

Commander, Harry Diamond Laboratories, Connecticut Avenue and Van Ness St., N.W., Washington, D. C. 20438

ATTN: AMXDO-NP

AMXDO-RBH/J. Gwaltney

Project Manager, Remotely Monitored Battlefield Sensor

System, AMC, Fort Monmouth, New Jersey 07703.

ATTN: Chuck Higgins

Commanding Officer, Picatinny Arsenal, Dover, New Jersey 07801

ATTN: Technical Library

$P$. Angelloti

SMUPA-ND-S/E. Zimpo

Ray Moessner

SUMPA-AD-D-A 


\section{Army (Continued)}

Director, U. S. Army Ballistic Research Laboratories,

Aberdeen Proving Ground, Maryland 21005

ATTN: W. J. Taylor

AMXBR-TB/J. T. Frasier

G. Grabarek

G. Roecker

Technical Library/Edward Baicy

J. W. Apgar

Conmander/Director, U. S. Army Cold Regions Research and

Engineering Laboratory, P. 0. Box 282, Hanover,

New Hampshire 03755

ATTN: G. Swinzow

Director, U. S. Army Engineer Waterways Experiment Station,

P. 0. Box 631, Vicksburg, Mississippi 39180

ATTN: Mr. John Strange

Mr. L. F. Ingram

Library

Mr. William J. Flathau

Dr. Guy Jackson

Dr. Behzad Rohani

Mr. Allen D. Rooke

Mr. D. K. Butler

Dr. Paul Hadala

Conmander, U. S. Army Materials and Mechanics Research Center, Watertown, Massachusetts 02172

ATTN: John Mescall

Director, U. S. Army Material Systems Analysis Agency,

U. S. Army Aberdeen R\&D Center, Aberdeen Proving Ground,

Maryland 21005

ATTN: M. Reches

Commander, U. S. Army Mobility Equipment R\&D Center,

Fort Belvoir, Virginia 22060

ATTN: STSFB-XS

Commandant, U. S. Army Engineer School, Fort Belvoir,

Virginia 22060

ATTN: S. Grazier 
Commander, U. S. Army Materiel Command, 5001 Eisenhower Avenue, Alexandria, Virginia 22333

ATTN: Technical Library

AMCRD-WN

AMCRD-BN

Commander, U. S. Army Missile Command, Redstone Arsenal, Alabama 35809

ATTN: Technical Library

F. Fleming

W. Jann

Commander, U. S. Army Nuclear Agency, Fort Bliss, Texas 79916 ATTN: MAJ F. P. Weiche1

COL Quinn

Technical Library

Document Control

Commandant, U. S. Army War College, Carlisle Barracks,

Pennsylvania 17013

ATTN: Library

Commander, U. S. Army Armament Command, Rock Island Arsenal,

Rock Island, Illinois 61201

ATTN: COL C. Treat

Technical Library

\section{Navy}

Chief of Naval Research, Department of the Navy, Arlington, Virginia 22217

ATTN: Technical Library

Officer in Charge, Civil Engineering Laboratory, Naval

Construction Battalion Center, Port Hueneme, California 93041

ATTN: Technical Library

Commander, Naval Facilities Engineering Command, Hoffman

Building, 200 Stovall Street, Alexandria, Virginia 22332

ATTN: Technical Library, Code 0911C

Superintendent, U. S. Naval Postgraduate School, Monterey, California 93940

ATTN: Library, Code 2124 


\section{Navy}

Director, Naval Research Laboratory, Washington,

D. C. 20375

ATTN: Code 2027/Tech Library

Commander, Naval Surface Weapons Center, White Oak, Silver

Spring, Maryland 20910

ATTN: Technical Library, Code 730

Code 1224 Navy Nuc Prgms Off

Commander, Naval Surface Weapons Center, Dahlgren Laboratory, Dahlgren, Virginia 22448

ATTN: Ted Williams

Technical Library

M. Weiland

Commander, Naval Weapons Center, China Lake,

California 93555

ATTN: Code 603, Dr. Carl Austin

Code 533, Technical Library

Commander, Naval Weapons Evaluation Facility,

Kirtland AFB, Albuquerque, New Mexico 87117

ATTN: Technical Library

Director, Strategic Systems Project Office, Navy Department, Washington, D. C. 20376

ATTN: NSP-43, Technical Library

\section{Air Force}

Air Force Armament Laboratory (AFSC), Eglin AFB, Florida 32542

ATTN: Technical Library

CPT Larry Looney

Dr. Kulp

Mr. Masey Valentine

MAJ Thomas Tomasetti

Mr. John Collins

Air Force Institute of Technology, AFIT B1dg 640, Area B,

Wright-Patterson AFB, Ohio 45433

ATTN: Technical Library 
Commander, Air Force Weapons Laboratory (AFSC), Kirtland Air Force Base, New Mexico 87117

ATTN: SUL, Technical Library

Headquarters, Air Force Systems Command, Andrews AFB, Washington, D. C. 20331

ATTN: Technical Library

Oklahoma State University, Field Office for Weapons Effectiveness, P. O. Box 1925, Eglin Air Force Base, Florida 32542

ATTN: Ed Jackett

Air Force Office of Scientific Research, 1400 Wilson Boulevard, Arlington, Virginia 22209

ATTN: LTC L. P. Mosteller, Jr.

Commander, Rome Air Development Center (AFSC), Griffiss Air Force Base, New York 13440

ATTN: EMTLD, Documents Library

Commander, Armament Development and Test Center, Eglin Air Force Base, Florida 32542

ATTN: Technical Library

Commander, Foreign Technology Division (AFSC), Wright-Patterson AFB, Ohio 45433

ATTN: Technical Library

HQ USAF/IN, Washington, D. C. 20330

ATTN: INATA

HQ USAF/RD, Washington, D. C. 20330

ATTN: RDMP, COL J. E. McCormick 1

Space and Missile Systems Organization, Norton Air Force Base, California 92409

ATTN: DEB

U. S. Energy Research and Development Administration

U. S. Energy Research and Development Administration, Division of Military Application, Washington, D. C. 20545 ATTN: Doc Control for. Test Office 
ER\&DA (Continued)

U. S. Energy Research \& Development Administration, Albuquerque Operations Office, P. O. Box 5400, Albuquerque, New Mexico 87115

ATTN: Technical Library

U. S. Energy Research and Development Administration, Division of Headquarters Services, Library Branch G-043, Washington, D. C. 20545

ATTN: Doc Control for Class Tech Lib

U. S. Energy Research and Development Administration, Nevada Operations Office, P. O: Box 14100, Las Vegas, Nevada 89114 ATTN: Technical Library

Los Alamos Scientific Laboratory, P. 0. Box 1663, Los Alamos, New Mexico 87544

ATTN: Doc Control for Tom Dowler

Report Librarian

Doc Control for G. Dials

Sandia Laboratories, Livermore Laboratory, P. 0. Box 969, Livermore, California 94550

ATIN: Doc Control for T. Gold Technical Library

Sandia Laboratories, P. 0. Box 5800, Albuquerque,

New Mexico 87115

ATTN: Doc Control for John Colp

Dr. Walter. Herrmann

Doc Control for John Keizur

Doc Control for William Patterson

Doc Control for William Caudle

Doc Control for 3141 Sandia Rpt Col1

Doc Control for W. Altsheimer

Director, Lawrence Livermore Laboratory,

P. 0. Box 808, Livermore, California 94550

ATTN: Larry Woodruff, L-125

Technical Information Division, Technical Library Mark Wilkins 


\section{Other Government Agencies}

Bureau of Mines, Twin Cities Research Center, P. 0. Box 1660, Minneapolis, Minnesota 55111

ATTN: R. E. Thill

\section{DOD Contractors}

Aerospace Corporation, P. O. Box 92957, Los Angeles, California 90009

ATTN: Technical Information Services

Applied Theory Incorporated, 1010 Westwood Boulevard, Los Angeles, California 90024

ATTN: Dr. John G. Trulio

AVCO, Government Products Group, 201 Lowe11 Street,

Wilmington, Massachusetts 01887

ATTN: David Henderson

Research Library A830, Room 7201

Boeing Company, Aerospace Group, Missile and Information

Systems Division, P. 0. Box 3707, Seattle,

Washington 98124

ATIN: Reynold Atlas

California Research and Technology, Inc., 6269 Variel Avenue, Woodland Hills, California 91364

ATTN: Technical Library

Dr. K. N. Kreyenhagen

General Electric Company, TEMPO-Center for Advanced Studies, 816 State Street, Santa Barbara, California 93102 ATTN: DASIAC

IIT Research Institute, 10 West 35th Street, Chicago, Illinois 60616

ATTN: Technical Library

Institute for Defense Analyses, 400 Army-Navy Drive, Arlington, Virginia 22202

ATTN: Ruth S. Smith, Librarian 
$\underline{\text { DOD Contractors (Continued) }}$

Kaman Avidyne, Division of Kaman Sciences Corp.,

83 Second Avenue, Northwest Industrial Park, Burlington, Maryland 01803

ATTN: E. S. Crisicone

Kaman Sciences Corporation, P. O. Box 7463, Colorado Springs, Colorado 80933

ATTN: Technical Library

Lockheed Missiles and Space Company, 3251 Hanover Street, Palo Alto, California 94304

ATTN: Tech Info Center D/Co11

Lockheed Missiles and Space Company, Inc., P. 0. Box 504, Sunnyvale, California 94088

ATTN: Technical Library

Martin Marietta Aerospace, Orlando Division, P. O. Box- 5837, Orlando, Florida 32805

ATTN: M. Anthony

Al Cowan

University of New Mexico, Dept of Campus Security and Police,

1821 Roma N.E., Albuquerque, New Mexico 87106

ATTN: G. E. Triandafalidis

Physics International Company, 2700 Merced Street, San Leandro, California 94577

ATTN: Mr. Dennis. Orphal

Mr. Larry Behrman

Technical Library

R\&DD Associates, P. O. Box 3580, Santa Monica, Califormia 90403 ATTN: Technical Library

Mr. J. G. Lewis

Dr. H. F. Cooper, Jr.

1

Dr. Harold L. Brode

Mr. William B. Wright

Dr. C. P. Knowles

Science Applications, Inc., 7850 Edgewater Drive, Oakland, California 94621 ATTN: Dr. D. E. Maxwe11 


\section{DOD Contractors (Contimued)}

Science Applications, Inc., 1911 North Ft. Myer Drive,

Suite 808, Arlington, Virginia 22209

ATTN: Dr. W. M. Layson

Stanford Research Institute, 333 Ravenswood Avenue, Menlo Park, California 94025

ATTN: Dr. G. Abrahamson

Systems, Science and Software, P. O. Box 1620, La Jo1la, California 92037

ATTN: Technical Library

Dr. Donald R. Grine

Dr. E. W. Gaffney

Terra Tek, Inc., University Research Park, 420 Wakara Way,

Salt Lake City, Utah 84108

ATTN: Mr. S. J. Green

Technical Library

Texas AG̣M University, Department of Civi1 Engineering,

College Station, Texas 77843

ATTN: Prof L. J. Thompson

Braddock, Dunn, \& McDonald, Inc., 1920 Aline Ave., Vienna, Virginia 22180

ATTN: Technical Library

TRW Systems Group, One Space Park, Redondo Beach,

California 90278

ATTN: Tech Info Center/S-1930

Weidlinger Associates, Consulting Engineers,

110 East 59th Street, New York, New York 10022

ATTN: Dr. Melvin L. Baron

Weidlinger Associates, Consulting Engineers,

2710 Sand Hill Road, Suite 230, Menlo Park,

California 99025

ATTN: Dr. J. Isenberg 


\section{DOD Contractors (Continued)}

Lowe11 Technical Institute, Department of Civil Engineering, Lowe11, Massachusetts 01854

ATTN: L. W. Thigpen

Georgia Institute of Technology, Department of Aerospace

Engineering, Atlanta, Georgia 30332

ATTN: L. N. Rehfield

Pacifica Technology, Inc., P. 0. Box 148, De1 Mar,

California 92014

ATTN: Dr. R. L. Bjork

Shock Hydrodynamics, Incorporated, 15010 Ventura Boulevard, Sherman Oaks, California 91403

ATTN: Dr. L. Zernow

Foreign Exchanges

Federal Bureau for Highway Engineering, Cologne,

West Germany (ENG-366)

Department of Physical Geography, Uppsala University, Box 554, S-75122, Uppsala, Sweden (ENG-374)

Prof. Leopold Muller, Abteilung Felsmechanik, Institut fur Bodenmechanik und Felsmechanik, Universitat Karlsruhe, 75 Karlsruhe, Germany (ENG-383)

\section{Domestic Exchange}

Manager, Engineering Design and Construction, Tennessee

Valley Authority, 600 Union Building, Knoxville, Tennessee 37902 